\title{
Preliminary Recommendations on
} the Design of the Characterization Program for the Hanford Site SingleShell Tanks-A System Analysis

Volume 2 - Closure-Related Analyte Priorities, Concentration Thresholds, and Detection Limit Goals Based on Public Health Concerns

J. W. Buck

M. S. Peffers

S. T. Hwang

November 1991

Prepared for the U.S. Department of Energy under Contract DE-AC06-76RLO 1830

Pacific Northwest Laboratory Operated for the U.S. Department of Energy by Battelle Memorial Institute 


\title{
DISCLAIMER
}

This report was prepared as an account of work sponsored by an agency of the United States Government. Neither the United States Government nor any agency thereof, nor Battelle Memorial Institute, nor any of their employees, makes any warranty, expressed or implied, or assumes any legal liability or responsibility for the accuracy, completeness, or usefulness of any information, apparatus, product, or process disclosed, or represents that its use would not infringe privately owned rights. Reference herein to any specific commercial product, process, or service by trade name, trademark, manufacturer, or otherwise does not necessarily constitute or imply its endorsement, recommendation, or favoring by the United States Government or any agency thereof, or Battelle Memorial Institute. The views and opinions of authors expressed herein do not necessarily state $r$ reflect those of the United States Government or any agency thereof.

\author{
PACIFIC NORTHWEST LABORATORY \\ operated by \\ BATTELLE MEMORIAL INSTITUTE \\ for the \\ UNITED STATES DEPARTMENT OF ENERGY \\ under Contract DE-ACO6-76RLO 1830
}

Printed in the United States of America

Available to DOE ant DOE contractors from the

Office of Scientific and Technical Informaition, P.O. Box 62, Oak Ridge, TN 37831; prices available from (615) 5;6-8401. FTS 626-8401.

Available to the public from the National Techıs:aal Information Service, U.S. Department of Commerce, 5285 Port Royal Rd., jipringfield, VA 22161. 
PNL-7573 Vol. 2

A Research Report for Westinghouse Hanford Company

PRELIMINARY RECOMMENDATIONS ON

THE DESIGN OF THE CHARACTERIZATION

PROGRAM FOR THE HANFORD SITE SINGLE-

SHELL. TANKS - A SYSTEM ANALYSIS

PNL--7573-Vol.2

Volume 2 - Closure-Related Analyte

DE92 004643

Priorities, Concentration Thresholds, and Detection Limit Goals Based on

Public Health Concerns

J. W. Buck

M. S. Peffers

S. T. Hwang

Noverner 1991

Prepared for

the U.S. Department of Energy

under Contract DE-AC06-76RLO 1830

Pacific Northwest Laboratory

Richland, Washington 99352

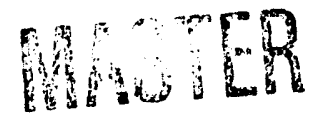


Preliminary Recommendations on the Design of the Characterization Program for the Hanford Site Single-Shell Tanks -. A System Analysis will appear in four volumes:

- Volume 1 contains a summary of the overall system analysis, including a summary of observations and recommendations.

- Volume 2 contains the recommendations on closure-related analyte priorities, concentration thresholds, and goals for analytical detection limits based on public health concerns.

- Volume 3 contains estimates of associated resource requirements and impacts for a number of alternate characterization program designs. These cases are evaluated in terms of radiological dose to characterization workers, schedule impacts (compared to the milestones in the Tri-Party Agreement), and manpower requirements.

- Volume 4 contains a preliminary evaluation of remediation decision quality for alternate characterization program designs; that is, Volume 4 provides information on uncertainties associated with the generation of tank inventory estimates. This includes an estimate of the likelihood of a leave/retrieve decision error as a function of the numbers of risers sampled per tank.

This document, Volume 2, is the first of the series to be issued; it is being distributed ahead of the others because the information contained here is intended to support Westinghouse Hanford Company in characterization activities to be started in the summer of 1991. Volumes 1, 3, and 4 are currently being prepared and will be issued later. 


\section{EXECUTIVE SUMMARY}

The Preliminary Recommendations Report consists of four volumes that provide recommendations and data quality objectives (DQOS) for designing and implementing the waste characterization program and closure decisions for the single-shell tanks (SSTS) at the Hanford Site. It is a systems analysis approach to provide information and preliminary DQOs for the SST waste characterization program. This document, Volume 2, is the first of the series of four volumes to be completed. This volume provides recommendations based on the ranking of closure-related analytes, concentration threshold (CT) values, and proposed detection limit goals (DLGs). These recommendations are based on public health and regulatory concerns.

The preliminary recommendations in this volume focus on identifying significant SST analytes and establishing analytical detection limit goals for them. The recommendations from this volume will be applied during characterization Phase IC (the third phase of a multiple-sampling plan) as DQOs for waste characterization and closure decision determinations for SSTs at the Hanford Site.

The objectives of the work described in this volume are 1) to prioritize SST analytes for sampling and analysis and 2) to define significant contributing analytes and their DLGs using the CT concept. The CT concept defines the level at which an analyte concentration in the tank potentially becomes a significant risk contributor to public health. The CT concept can be used to identify analytical detection limits that may need to be improved for the characterization program and that can be used as input for selecting closurerelated decisions.

This volume contains the following recommendations:

- Recommendation 2-1: Inventory estimates for the Type I and II analytes (those which present the highest potential risk) should be generated for the Limited Phase IC Characterization program in association with closure decisions. These analytes should receive the greatest attention in terms of analytical accuracy requirements. 
- Recommendation 2-2: The Limited Phase IC Characterization program should include tests for reducing the uncertainties associated with closure-related analyte priorities. This includes empirical solubility limits (i.e., source-term data) and adsorption coefficients (i.e., $K_{d}$ values) in support of Long-Term Release Risk assessments (i.e. performance assessments). This information should be generated over a diverse set of waste types.

- Recommendation 2-3: To the extent feasible, analyses conducted under the Limited Phase IC Characterization program should be designed so that analytical detection limits are one order-ofmagnitude below computed Short-Term Intruder Risk and Waste Classification CT values and two orders-of-magnitude below computed Long-Term Release Risk CT values.

- Recommendation 2-4: The Extended Phase IC Characterization program should be designed so that there is sufficient confidence that when detection limits are not exceeded the true concentration does not exceed the computed $\mathrm{CT}$ value.

The recommendations presented here may be helpful in determining costs and schedules for waste characterization. The work and recommendations in this volume are preliminary; as more information is obtained on the character of SST waste, better estimates of anaiyte priorities, CT values, and DLGs can be made.

This volume is being distributed before the others because it contains information important to the SST characterization efforts that are planned for 1991. This document was prepared by Pacific Northwest Laboratory for the Westinghouse Hanford Company, the current operating contractor on the Hanford Site for the U.S. Department of Energy. 


\section{ACKNOWLEDGMENTS}

This report could not have been completed without the help of many other people. The authors would like to acknowledge those who worked on or reviewed this document.

We would like to extend a special acknowledgement to Bob Wegeng, who was the PNL project manager of the SST Waste Characterization Project when this study began. Bob provided a great deal of technical insight for the analyses and the structure of the report. The authors woula also like to thank the current project manager, Tom Wood, for his continuing support. We would like to thank the WHC project managers, Vern Hall and Al Noonan, for their support.

A report can not be completed without peer review. The comments and suggestions we received from the PNL and WHC peer reviewers were very usefuT. We would like to thank Jeff Serne of PNL for his insights and guidance on the work associated with this study. Jim Droppo, Pete Chamberlain, Daryl Baird, and Tom Jones of PNL also provide helpful input to the analyses for this report. We would also like to thank Bill Winters, Julian Hill, Leela Sasaki, and Bob Miller of WHC for their constructive comments.

No report can be completed without support from editing and text processing personnel. The authors would like to thank Sheila Bennett, Dave Payson, Darby Stapp, and Pat Hays for providing excellent editorial support on this report. The hard work by Gene Wattenburger and the graphics group and Marlene Hale and others in the text processing team made the report a reality. 


\section{ACRONYMS AND ABBREVIATIONS}

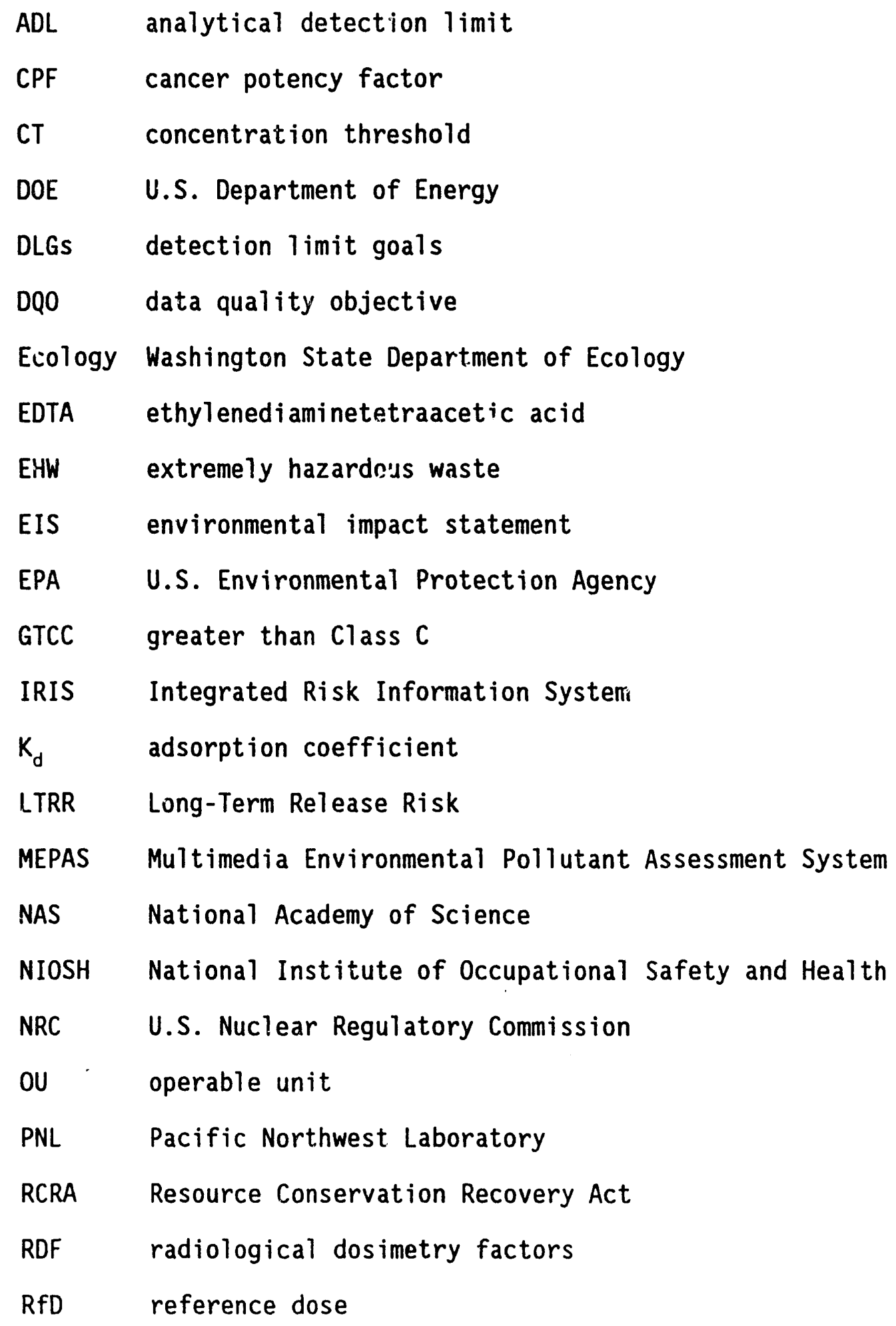


SEIS supplemental environmental impact statement

SST single-shell tank

STIR short-term intruder risk

TEC toxicity equivalent concentration

TRAC Tracks radioactive components

WAC Washington Administrative Code

WC Waste Classification

WCP Waste Characterization PIan

WHC Westinghouse Hanford Company 


\section{CONTENTS}

PREFACE ........................... . .

EXECUTIVE SUMMARY .......................... . . v

ACKNOWLEDGMENTS ........................ . . . . vii

ACRONYMS AMD ABBREVIATIONS ..................... ix

1.0 INTRODUCTION ....................... . . . . . . . . . .

1.1 DESCRIPTION OF SINGLE-SHELL TANKS AT THE HANFORD SITE . . . . . . 1.2

1.2 EARLY EFFORTS TO CHARACTERIZE SINGLE-SHELL TANK WASTE . . . 1.4

1.3 DESCRIPTION OF SINGLE-SHELL TANK WASTE CHARACTERIZATION PLAN . . . . . . . . . . . . . . . . . . . 1.7

1.4 REASONS FOR ISSUING THIS REPORT . . . . . . . . . . . 1.10

1.5 VOLUME OUTLINE . . . . . . . . . . . . . . . 1.10

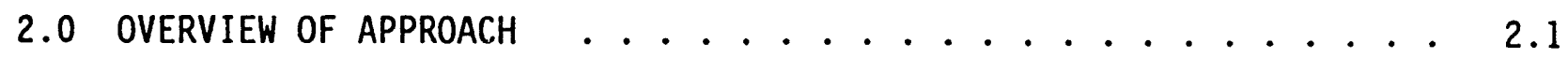

2.1 DIFFERENT METHODS OF RANKING ANALYTES . . . . . . . . . 2.1

2.2 SELECTION OF ANALYTE PRIORITIES . . . . . . . . . . . . 2.4

2.3 DETERMINATION OF CONCENTRATION THRESHOLD VALUES . . . . . 2.7

2.4 APPLICATION OF THE CONCENTRATION THRESHOLD CONCEPT $\ldots \ldots$

3.0 SINGLE-SHELL TANK ANALYTE RANKING ANALYSIS . . . . . . . . . 3.1

3.1 LONG-TERM RELEASE RISK RANKING METHOD . . . . . . . . . . 3.1

3.1.1 Long-Term Release Risk Ranking Scenario Definition . 3.1

3.1.2 Long-Term Release Risk Ranking Scenario Results . . . 3.6

3.2 SHORT-TERM INTRUDER RISK RANKING SCENARIO . . . . . . . . . 3.7

3.2.1 Short-Term Intruder Risk Ranking Scenario
Definition ...................... 3.8

3.2.2 Short-Term Intruder Risk Ranking Scenario Results . . 3.11

3.3 WASTE CLASSIFICATION RANKING METHOD . . . . . . . . . . 3.14 
3.3.1 Dangerous Waste Classification Description

\subsubsection{Low-Level Radioactive Waste Classification} Description

3.3.3 Waste $\mathrm{Classification} \mathrm{Ranking} \mathrm{Method} \mathrm{Results} \mathrm{.} \mathrm{.} \mathrm{.} \mathrm{.} 3.16$

4.0 CONCENTRATION THRESHOLD VALUES FOR SINGLE-SHELL TANK ANALYTES . . 4.1

4.1 LONG-TERM RELEASE RISK CONCENTRATION THRESHOLD VALUES . . . 4.2

4.2 SHORT-TERM INTRUDER RISK CONCENTRATION THRESHOLD VAL!IFS . . 4.3

4.3 WASTE CLASSIFICATION CONCENTRATION THRESHOLD VALUES . . . . 4.3

4.4 APPLICATION OF THE CONCENTRATION THRESHOLD CONCEPT . . . . . 4.4

5.0 RESULTS AND CONCLUSIONS . . . . . . . . . . . . . . 5.1

5.1 SELECTION OF ANALYTE PRIORITIES . . . . . . . . . . 5.3

5.2 DETERMINATION OF CONCENTRATION THRESHOLD VALUES . . . . . 5.3

5.3 DETECTION LIMIT GOALS BASED ON HEALTH RISK . . . . . . . . . 5.10

6.0 REFERENCES ...................... 6.1

APPENDIX A - DESCRIPTION OF LONG-TERM RELEASE RISK ANALYTE METHOD BY TANK FARM GROUP .................. A. . .

APPENDIX B - RADIOACTIVE WASTE AND NIOSH TOXICITY CLASSIFICATION FOR SINGLE-SHELL TANK ANALYTE ANALYSIS . . . . . . . . B. 1

APPENDIX C - RISK INDEX CALCULATIONS FOR ANALYTES WITH DECAY PRODUCTS ................... C.1

APPENDIX D - COMPARISON OF CONCENTRATION THRESHOLD VALUES TO STANDARD HEALTH IMPACT LEVELS .............. . . D.

APPENDIX E - CONCENTRATION THRESHOLD LIMITS FOR LONG-TERM RELEASE RISK, SHORT-TERM INTRUDER RISK, AND WASTE CLASSIFICATION RANKING METHODS BY TANK FARM GROUPS . . . . . . . . . . . E.1

APPENDIX $F$ - COMPARISON OF DETECTION LIMIT GOALS, ANALYTICAL DETECTION LIMITS, AND 241-B-110 TRAC AND MEASURED CONCENTRATIONS 


\section{FIGURES}

1.1 Wastes Contained in the Hanford Single-Shell Tanks Require Characterization in Order to Make Prudent Closure Decisions . . . 1.3

1.2 Schematic of the Location of Single-Shell Tanks and Other Related Facilities in the 200 Areas . . . . . . . . . . . 1.5

1.3 Relationship Between the Preliminary Recommendations Report and the Waste Characterization Plan ............. 1.11

1.4 Overview of the Preliminary Recommendations Report . . . . . . 1.12

3.1 The Single-Shell Tank Analyte Ranking Process Using the l.ong-Term Release Risk Ranking Method . . . . . . . . . . 3.4

3.2 The Single-Shell Tank Analytes Ranking Process Using the Short-Term Release Risk Ranking Method . . . . . . . . . . 3.13

3.3 The Single-Shell Tank Analyte Ranking Process Using the Waste Classification Ranking Method . . . . . . . . . . . 3.18

5.1 Diagram of the Single-Shell Tank Analyte Ranking Process Using Al1 Three Ranking Methods . . . . . . . . . . . . . . 5.5

5.2 Diagram of the Single-Shell Tank Analyte Concentration Threshold Values Using the Most Restrictive Values . . . . . . . . . 5.9

5.3 Diagram of the Relationship Between the Single-Shell Tank Analyte Ranking, Concentration Threshold Values, and Proposed Detection Limit Goals Using All Three Methods . . . . . . . . 5.12 


\section{$\underline{\text { TABLES }}$}

2.1 List of Analytes of Fotential Concern . . . . . . . . . 2.5

2.1 List of SST Analytes Without Tank Inventories . . . . . . . . 2.6

3.1 Carcinogen Analyte Ranking Based on Long-Term Release P.isk . . 3.6

3.2 Voncarcinogen Analyte Ranking Based on Long-Term Release Risk . . 3.8

3.3 Carcinogen Analyte Ranking Based on Short-Term Intruder Risk . . 3.11

3.4 Noncarcinogen Analyte Ranking Based on Short-Term Intruder Risk . 3.12

3.5 Carcinogen Analyte Ranking Based on Waste Classification . . . 3.16

3.6 Noncarcinogen Analyte Ranking Based on Waste Classification . . 3.17

5.1 Combined $\varsigma$ T Analyte Ranking . . . . . . . . . . . . . 5.4

5.2 Alternate Combined SST Analyte Ranking . . . . . . . . . . 5.6

5.3 Concentration. Threshold Values for Carcinogen Analytes . . • . 5.7

5.4 Concentration Threshold Values for Noncarcinogen Analytes . . . 5.8

5.5 Single-Shel1 Tank Analytes with Suspect Analytical Detection

5.6 Single-Shell Tank Analytes with Suspect Analytical Detection Lirrits and that Appear to be in Small quantities . . . . . . 5.14

5.7 Imporiant Analytes that Need Analytical Detection Limits to be Determined .. . . . . . . . . . . . . . 5.15

A.1 Long-Term Release Risk Method Risk Indexes for Noncarcinogen and Carcinogens in Tank Farm Group A . . . . . . . . . . A.5

A.2 Long-Term Release Risk Method Risk Indexes for Noncarcinogen and Carcinogens in Tank Farm Group B . . . . . . . . . . A.6

A.3 Long-Term Release Risk Method Risk Indexes for Noncarcinogen and Carcinogens in Tank Farm Group C . . . . . . . . . . . A.7

A.4 Long-Term Release Risk Methor Risk Indexes for Noncarcinngen and Carcinogens in Tank Farm Group $S$. . . . . . . . . . . A.8

A.5 Long-Term Release Risk Method Risk Indexes for Noncarcinogen and Carcinogens in Tank Farm Group T. . . . . . . . . . . . . A.9 
A.6 Long-Term Release Risk Method Risk Indexes for Noncarcinogen and Carcinogens in Tank Farm Group U . . . . . . . . . . A.10

B.1 Long- and Short-Lived Radionuclide Concentrations Threshold . . . B.3

B.2 Equivalent Toxicity Category for Analytes and Other Compounds . . B.4

C.1 Parent-Daughter Relationships and Chemical Properties . . . . . C.3

D.1 Comparison of Concentration Threshold to Standard Risk Levels . . D.2

E.1 Long-Term Release Risk Ranking Scenario Concentration Thresholds for Carcinogenic Analytes . . . . . . . . . . . . . . E.1

E.2 Long-Term Release Risk Concentrations Thresholds for Noncarcinogenic Analytes .. . . . . . . . . . . . . E.2

E.3 Short-Term Intruder Risk Concentration Thresholds for Inhalation of Chemicals ................. E.3

E.4 Short-Term Release Risk Concentration Thresholds for Ingestion of Chemicals .................. E. A

E.5 Concentration Thresholds for Inhalation of Radionuclides . . . . E.5

E.6 Concentration Thresholds for Ingestion of Radionuclides . . . . . E.6

E.7 Concentration Thresholds for Ground Exposure of Radionuclides . . E.7

E.8 Concentration Thresholds for Waste Classification . . . . . . . E.8

E.9 Concentration Thresholds for Waste Classification Radionuclides . E.9

F.1 Detection Limit Goals, Analytical Detection Limits, and 241-B-110 TRAC and Measured Concentrations for Type I Carcinogens . . . . . . . . . . . . . . . . . F.1

F.2 Detection Limit Goals, Analytical Detection Limits, and 241-B-110 TRAC and Measured Concentrations for Type I Noncarcinogens

F.3 Detection Limit Goals, Analytical Detection Limits, and 241-B-110 TRAC and Measured Concentrations for Type II Carcinogens

F.4 Detection Limit Goals, Analytical Detection Limits, and 241-B-110 TRAC and Measured Concentrations for Type II Noncarcinogens 
F.5 Detection Limit Goals, Analytical Detection Limits, and 241-B-110 TRAC and Measured Concentrations for Type III

Carcinogens

F.6 Detection Limit Goals, Analytical Detection Limits, and 241-B-110 TRAC and Measured Concentrations for Type III Noncarcinogens . . . . . . . . . . . . . . . . . F.5

F.7 Detection Limit Goals, Analytical Detection Limits, and 241-B-110 TRAC and Measured Concentrations for Unranked Carcinogens

F.8 Detection Limit Goals, Analytical Detection Limits, and 241-B-110 TRAC and Measured Concentrations for Unranked Noncarcinogens 


\subsection{INTRODUCTION}

The work described in this volume was conducted by Pacific Northwest Laboratory $^{(a)}$ to provide preliminary recommendations on data quality objectives (DQOs) to support the Waste Characterization Plan (WCP) and closure decisions for the Hanford Site single-shell tanks (SSTs). The WCP describes the first of a two-phase characterization program that will obtain information to assess and implement disposal options for SSTs. This work was performed for the Westinghouse Hanford Company (WHC), the current operating contractor on the Hanford Site.

Data quality objectives provide decision makers with information on the type, quantity, and quality of the data needed to make closure decisions on SSTs. Accurate estimates of the inventories of the tanks are needed to categorize, treat, and close each SST. Unfortunately, the inventory of each tank is not well known; thus, it will require a detailed characterization program to supply the critical information on which to base decisions for disposal of the waste and closure of the tanks. It is also important to know which. analytes are most important (type of data) in the closure process and the analytical detection limits (ADLs) required for those analytes (quality of data) to properly characterize the waste in the tanks.

The preliminary DQOs contained in this volume deal with the analysis of SST wastes in support of the WCP and final closure decisions. (b) These DQOS include information on significant contributors and detection limit goals (DLGS) for SST analytes based on public health risk. Final closure decisions

(a) Pacific Northwest Laboracory is operated for the U.S. Department of Energy (DOE) by Battelle Memorial Institute.

(b) Final closure decisions are considered to be separate and distinct from safety issues associated with current and future storage of the SST wastes. This report does not address characterization of the SST wastes in support of resolving such safety issues. 
include "leave" or "retrieve" decisions(a) for each SST, and the selection and implementation of a remediation system for the ultimate disposition of the wastes. A "leave" decision for an SST indicates in-tank treatment of the waste (e.g., grouting or in situ vitrification), while a "retrieve" closure decision indicates removal of the waste and offsite disposal of at least some portion of the tank contents in a waste repository. For the purpose of this report, remediation decisions and closure decisions are considered to be synonymou:.

The recommendations and preliminary $000 \mathrm{~s}$ in this report pertain to the design of the characterization effort and provide information on sampling and analysis techniques that can reduce resources (worker impacts) and increase the value of characterization information obtained. The recommendations in this volume, the first of four volumes to be issued, focus on developing DQOS that determine requirements for identifying significant anaiytes and DLGs for the chararterization program. Subsequent volumes will deal with recommendations for the number of cures to be sampled from each tank and discuss the advantages and disadvantages of analyzing individual core segments versus core composites.

\subsection{DESCRIPTION OF SINGLE-SHELL TANKS AT THE HANFORD SITE}

The Hanford Site SST closure process involves 149 concrete underground storage tanks, each containing a single steel-she 11 liner and ranging in capacity from 55,000 to 1,000,000 galions (Figure 1.1). The tanks were designed to contain the chemical and radioactive waste products of nuclear fuel separation processes that were performed in the 200 East and 200 West

(a) For this report, the "leave/retrieve" question is considered to be a question regarding whether the waste in a tank can be acceptably disposed of while within the tank, or whether acceptable disposal will require retrieval (prior to processing and disposal). As such, resolution of the "leave/retrieve" question is part of the development of a closure plan for the tanks. A number of subtleties are involved in a "leave/retrieve" decision, including the possibility that the waste may have been judged to be unacceptable for near-surface disposal (e.g., containing transuranic wastes in concentrations greater than $100 \mathrm{nCi} / \mathrm{g}$ ) or that the most risk/cost-effective method for treating the waste requires that the waste first be retrieved. 

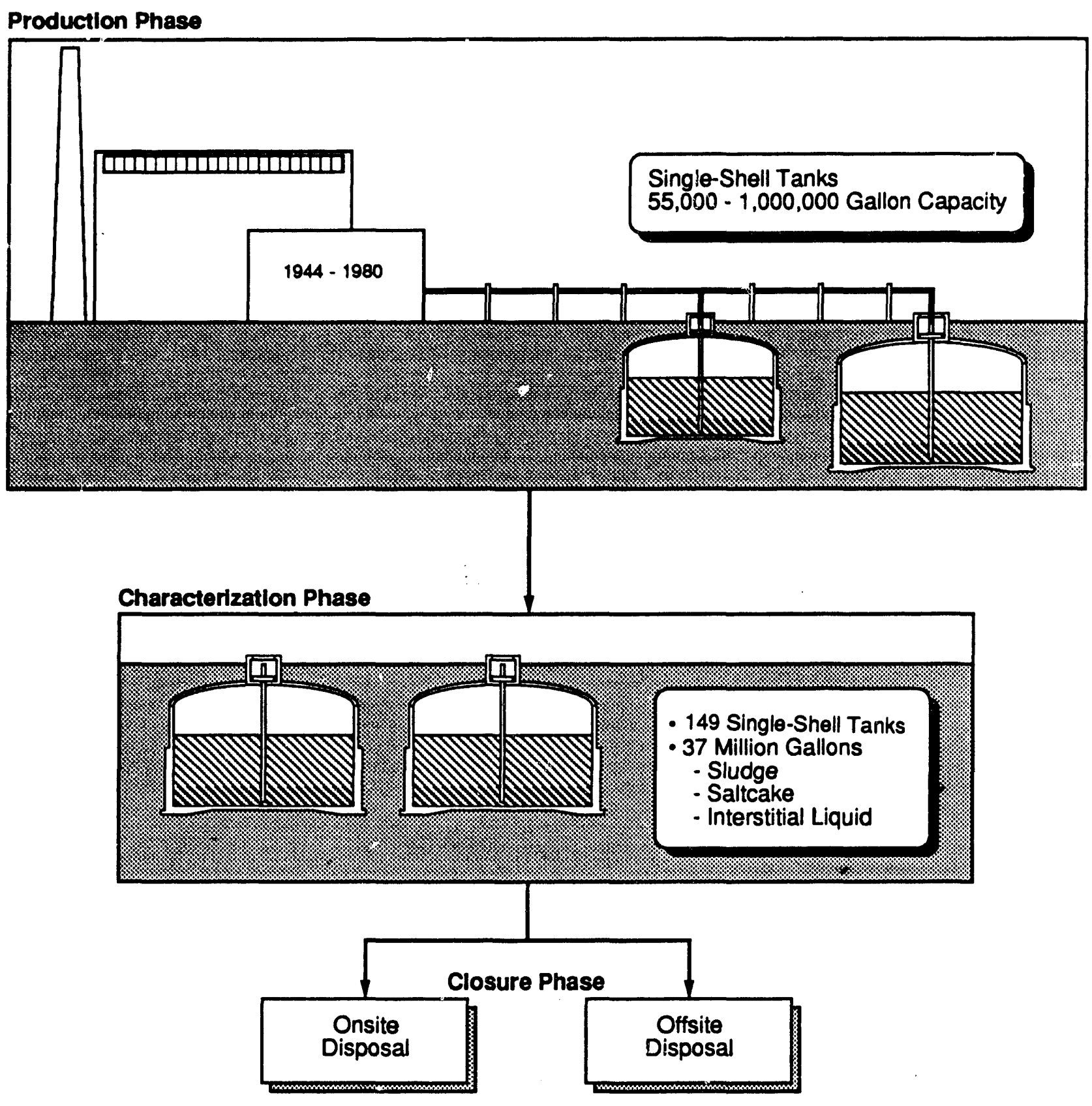

FIGURE 1.1. Wastes Contained in the Hanford Single-Shell Tanks Require Characterization in Order to Make Prudent Closure Decisions 
Areas of the Hanford Site (DOE 1987). The tanks, constructed between 1944 and 1964, currently contain approximately 37 million gallons of sludge, salt cake, and interstitial liquid. No additional wastes have been added to the tanks since 1980 .

The SSTs at the Hanford Site are situated in 12 tank farms located in the 200 East and West Areas. For this report, the 12 tank farms were grouped into the following six tank farm groups based upon geologic setting:

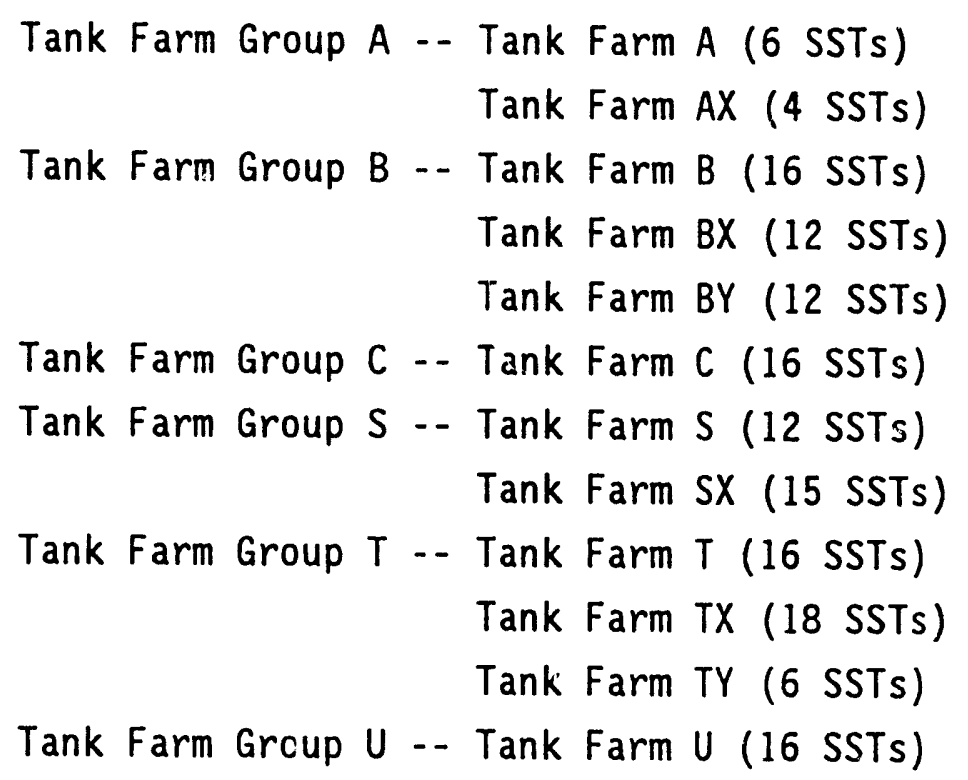

Figure 1.2 is a schematic of the location of the SSTs and other related faci1ities in the 200 Areas of the Hanford Site. The 12 SST tank farms have been reorganized into six operable units (OUs) since this work was started. As it turns out, three of the OUs contain the same SSTs as three of the tank farm groups (OU-200-BP-7 = Tank Farm Group B, OU-200-RO-4 = Tank Farm Group S, and OU-200-UP-3 = Tank Farm Group U). In the future, SSTs waste characteristics will be analyzed based on OUs, but for this volume, the tank farm group categories will be used.

\subsection{EARLY EFFORTS TO CHARACTERIZE SINGLE-SHELL TANK WASTE}

Waste management operations have complicated the characterization of the waste by intermingling different tank wastes and removing heat-producing 


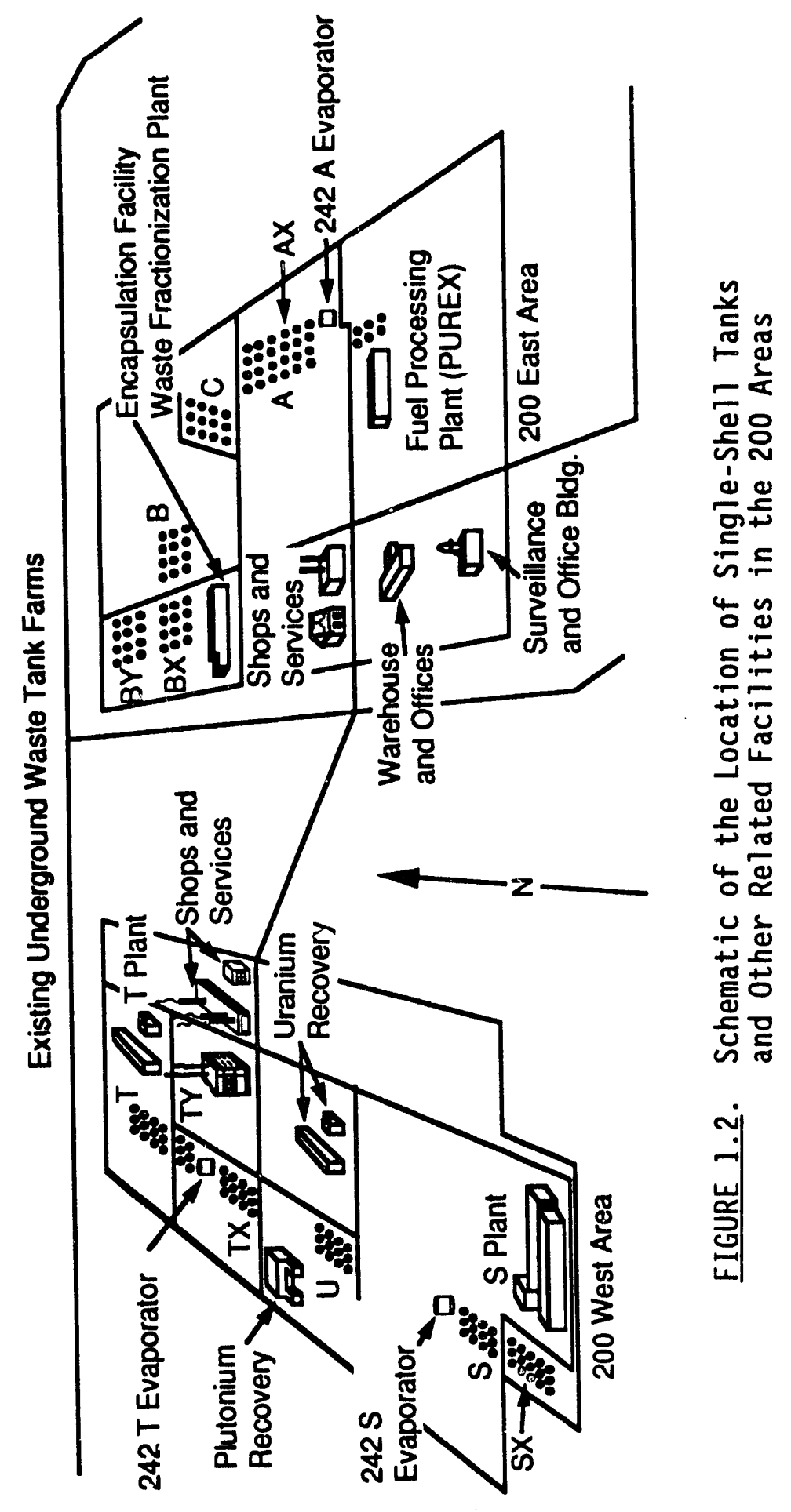


short-lived radionuclides $\left({ }^{99} \mathrm{Sr}\right.$ and $\left.{ }^{137} \mathrm{Cs}\right)$. Natural processes such as settling, stratification, and segregation of waste components further complicate ihe characterization of the waste. These waste management operations and natural processes make accurate estimates of inventory, volume, and distribution of waste in each tank extremely difficult.

In the early to mid-1980s, an effort to generate inventory estimates for SST wastes was conducted. A computer code called TRAC (Tracks Radioactive Components) was developed to estimate individual tank inventories based on nuciear fuels production models, reprocessing and waste management flowcharts, tank transfers, and radioactive decay calculations. In its completed form, the TRAC code estimates tank-by-tank inventories for 68 radionuclides and 36 nonradioactive components.

In 1985 and 1986, it was assumed that inventories generated by the TRAC code could be used to support final closure decisions. At that time, the characterization plan was designed to verify if TRAC provided reasonable estimates for radionuclide inventories for a select number of tanks. Once TRAC was verified, these inventory estimates would be used to make closure decisions for all SSTs.

Fifteen tanks were sampled in 1985 and 1986 using sampling equipment that was designed to retrieve a "core sample" by penetrating the dome of the tank through existing tank risers (access ports in the tanks). A core sample refers to the entire sample of waste taken from top to bottom of the tank and is made up of individual segments (Weiss 1986). Analyses can be run on core composites, cores, segments of cores, or visual strata within a segment. Using a preliminary list of six radionuclides considered to be of key interest for disposal decisions $\left({ }^{241} \mathrm{Am},{ }^{14} \mathrm{C},{ }^{129} \mathrm{I},{ }^{239} \mathrm{Pu},{ }^{240} \mathrm{Pu}\right.$ and $\left.{ }^{99} \mathrm{TC}\right)$, the data from the 15 sampled tanks were compared with TRAC data for this list of radionuclides. It was determined that, although TRAC may have predicted the relative abundance of individual constituents (Adams, Jensen, and Schulz 1986), it did not agree with actual sample results and thus could not be used to characterize SST wastes (Morgan et a1. 1988). As a result, the char-acterization program was reevaluated to account for inadequacies in the inventory estimates from the TRAC code. 


\subsection{DESCRIPTION OF SINGLE-SHELL TANK WASTE CHARACTERIZATION PLAN}

The Waste Characterization Plan (Winters et al. 1990) describes the first phase of a two-phase characterization program that will obtain information to assess and implement disposal options for the SSTs. The plan includes information on the waste to 1) ensure protection of human health and environment in handling of waste, 2) support regulatory requirements, 3) classify waste for disposal, and 4) obtain information on SST analytes to support developing technologies, supplemental environmental impact statements (SEIS), and closure plans.

An evaluation of SST closure options will be published for review and comment in an SEIS for the SSTS at the Hanford Site. This SEIS will then be used to determine the final closure options for the SSTs described in the Hanford Defense Waste Record of Decision report (53 FR 12449).

In 1987 and 1988, two important decisions were made that have influenced current characterization efforts. The first was DOE's decision that mixed radioactive waste is subject to regulation under the Resource Conservation and Recovery Act (RCRA 1976). The state of Washington was placed in a key position as a regulator of the management (storage and disposal) of SST waste, with authority over the chemical hazards in the tanks. The state agency with regulatory authority is the Washington State Department of Ecology (Ecology), which must be satisfied through a permit process before a closure plan can be implemented.

In 1988, a preliminary WCP was prepared for the SSTs at the Hanford Site (Winters et al. 1989). The plan acknowledged that sampling and analysis would be required for each of the 149 tanks to support tank-specific closure decisions. This plan was later revised; the current plan describes Phase I of a "multiple-sampling plan"(a) approach consisting of two phases (Winters et a1. 1990). Phase I characterization is designed to provide information for

(a) A multiple-sampling plan is a standard option considered by quality engineers in considering sample plans'which involve acceptance/rejection decisions. Where appropriate, multiple-sampling plans have the advantage of providing for higher confidence decisions, with lower resource requirements than associated with single-phase sampling plans. 
a preliminary classification of SSTs into three categories: retrieval candidates (retrieve), candidates for in-tank disposal (leave), and candidates for which no conclusions can be reached at this time. This preliminary sorting will focus the Phase II characterization on evaluating the onsite disposal and no-conclusion candidate tanks.

Parallel with developing the WCP, DOE, the U.S. Environmental Protection Agency (EPA), and Ecology negotiated and entered into an agreement on the institutional process and schedule for developing remediation systems for certain Hanford wastes. The single-shell-tank-associated milestones described in the joint Ecology, EPA, and DOE agreement (Ecology/EPA/DOE 1989), c.alled the Tri-Party Agreement, include interim milestones for characterization as well as milestones that relate to the development and demonstration of retrieval technology. The interim milestones associated with characterization are tied to the initiation of characterization activities within individual tanks.

To fulfill an interim characterization milestone, sampling on the two reference tanks (241-B-110 and 241-U-110) was initiated in August 1989. Fifteen cores had heen pulled by the end of December 1989, in accordance with the milestone. Virtually all analyses have been completed. However, due to significant, unanticipated difficulties in data management, only partial Phase IA data were available at the time the analyses in this report were generated. This consists of data for four cores from Tank 241-B-110.

A second important decision, one which sets expectations and certain protocol commitments for DOE, was the Record of Decision for the Hanford Defense Waste Environmental Impact Statement (53 FR 12449). In that decision, DOE concluded that characterization of the tank wastes, including consideration of chemical hazards, must occur before a closure option is selected, and that a separate SEIS would be prepared and issued for the SSTs.

Significant issues that were identified in developing a revised characterization program included the potential for errors in inventory estimates (and therefore in leave/retrieve decisions) associated with tank sampling, sample handling (including homogenization of samples and the creation of core composites), analytical techniques and horizontal variance within a tank (Jensen and Liebetrau 1988). 
The current WCP is based on requirements for a waste analysis plan for characterizing hazardous waste under RCRA and the Washington State Hazardous Waste Management Act, and on requirements under the Atomic Energy Act that address radioactivity. The plan contains requirements for parameter selection, sampling, and analytical methods to support closure decisions (synonymous with remediation decisions). Modifications to the pian will be made as new information is obtained from current analyses and testiiig.

Based on preliminary review meetings with a panel of the National Academy of Sciences (NAS), it was determined that the question of whether to analyze core composite or segment samples (vertical heterogeneity) wouid also be investigated. A research approach consisting of a cycle of testing, evaluating, and modifying $W_{C^{\prime}}$ procedures was suggested, prompting Phase $I$ to evolve into three elements:

- Phases IA and IB: Verify sampling and laboratory capability, provide for error estimates for the components of characterization, and generate other information pertinent to the design of the next element of Phase I using an initial group of tanks as a reference.

- Phase IC: Continue characterization within the remaining tanks. Data from Phase IA and IB would be used to determine, for Phase IC, 1) the number of cores to be sampled, 2) the need for segment analyses (rather than analyses on core composites), and 3) the appropriate use of duplicate aliquots in the overall sampling program. These three design items, while representing major control variables for the characterization effort, provide for the greatest influence in terms of impacts to the waste characterization program (i.e., radiological dose to characterization workers, costs, and schedules).

Phase IC uses all the information (especially the number of cores required to adequately characterize a tank) from Phases IA and IB to sample and analyze all of the SSTs. Phase IC consists of a Limited Phase IC, which is the next 1 to 2 years of characterization, and an Extended Phase IC, which completes the sampling of all SSTs. The Limited Phase IC allows for a transition in using and refining the procedures and techniques developed in the earlier part of Phase I. The Extended Phase IC will provide data for determining the closure decision of each SST that will be performed in Phase II. 


\subsection{REASONS FOR ISSUING THIS REPORT}

This report provides preliminary observations and recommendations for Phase IC characterization, based upon the partial data set available from Phase IA and IB. As previously noted, the currently incomplete data sets do not yet allow for some eva?uations that support completion of Phase IA and IB objectives.

The purpose of issuing this preliminary recommendations report is twofold. First, for some of the evaluations, such as radiological doses to workers and analyte priorities, the results do not depend upon additional data from Phase IA/IB. The proposed analyte priorities and DLGs that are documented here are intended to be used by WHC to support the WCP sampling and analysis of the next set of tanks to be sampled. This volume serves as a part of the technical basis for updating the WCP. Figure 1.3 shows the relationship between the Preliminary Recommendations Report and the different phases of the WCP.

A second reason for issuing preliminary material is to solicit comments on the methods currently in use. This is important because of the iterative nature of the WCP. Subsequent volumes of this report will describe the methodology used to evaluate issues such as the number of cores to be sampled per tank (Figure 1.4). Volume 1 will contain the comparative analysis and summary recommendations from the other volumes.

\subsection{VOLUME OUTLINE}

The outline for this volume is as follows: Chapter 1.0 has provided an overview of the history of SSTs at the Hanford Site, the Waste Characterization Plan, and the Tri-Party Agreement; Chapter 2.0 provides an overview of the approach used in this volume; Chapter 3.0 describes the process used to prioritize the SST analytes; Chapter 4.0 describes the concept of the concentration threshold and its applications; Chapter 5.0 summarizes the results, conclusions, and recommendations; and Appendixes $A$ through $F$ provide technical support to the work reported in this volume. 


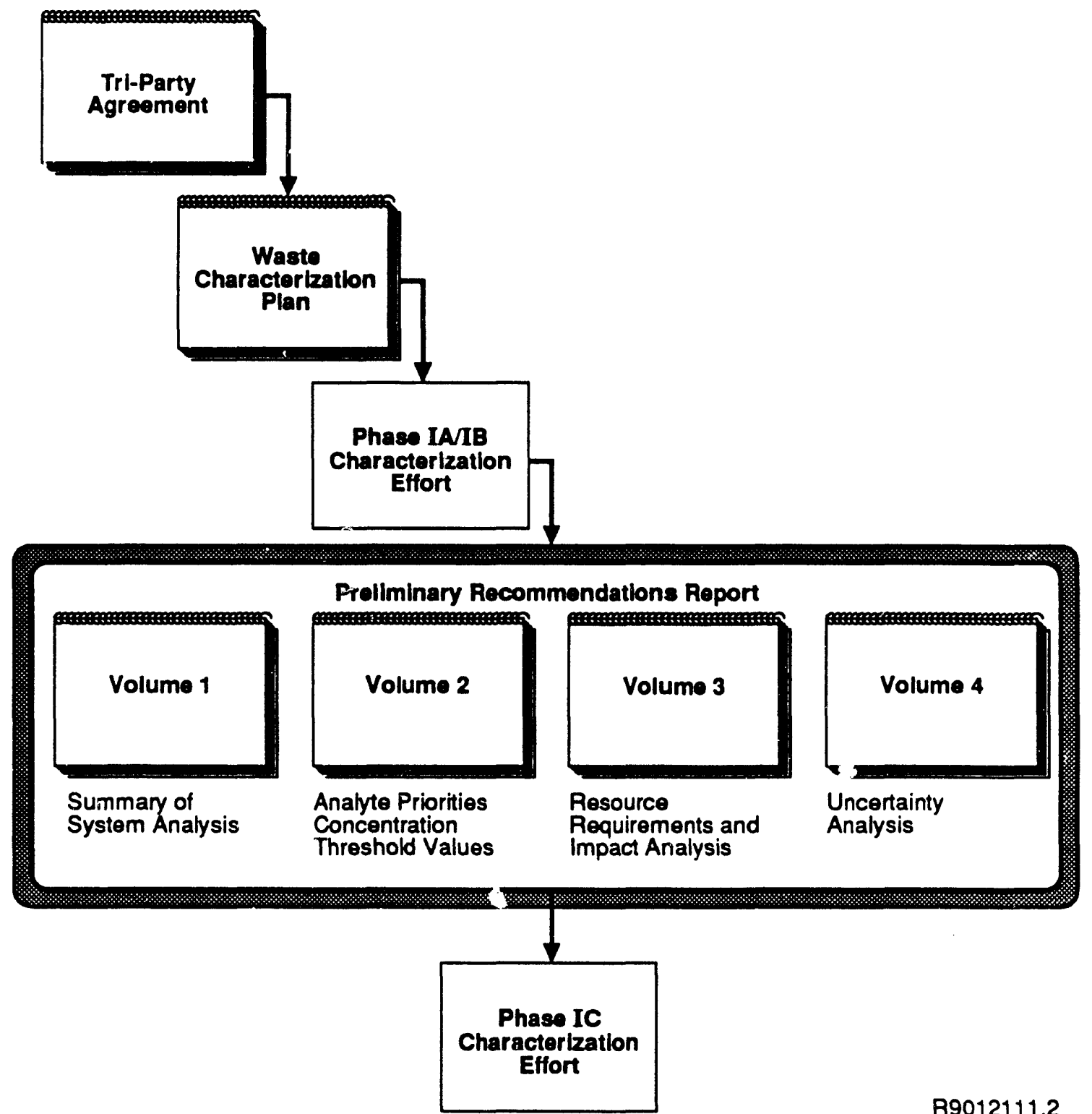

FIGIJRE 1.3. Relationship Between the Preliminary Recommendations Report and the Waste Characterization Plan 


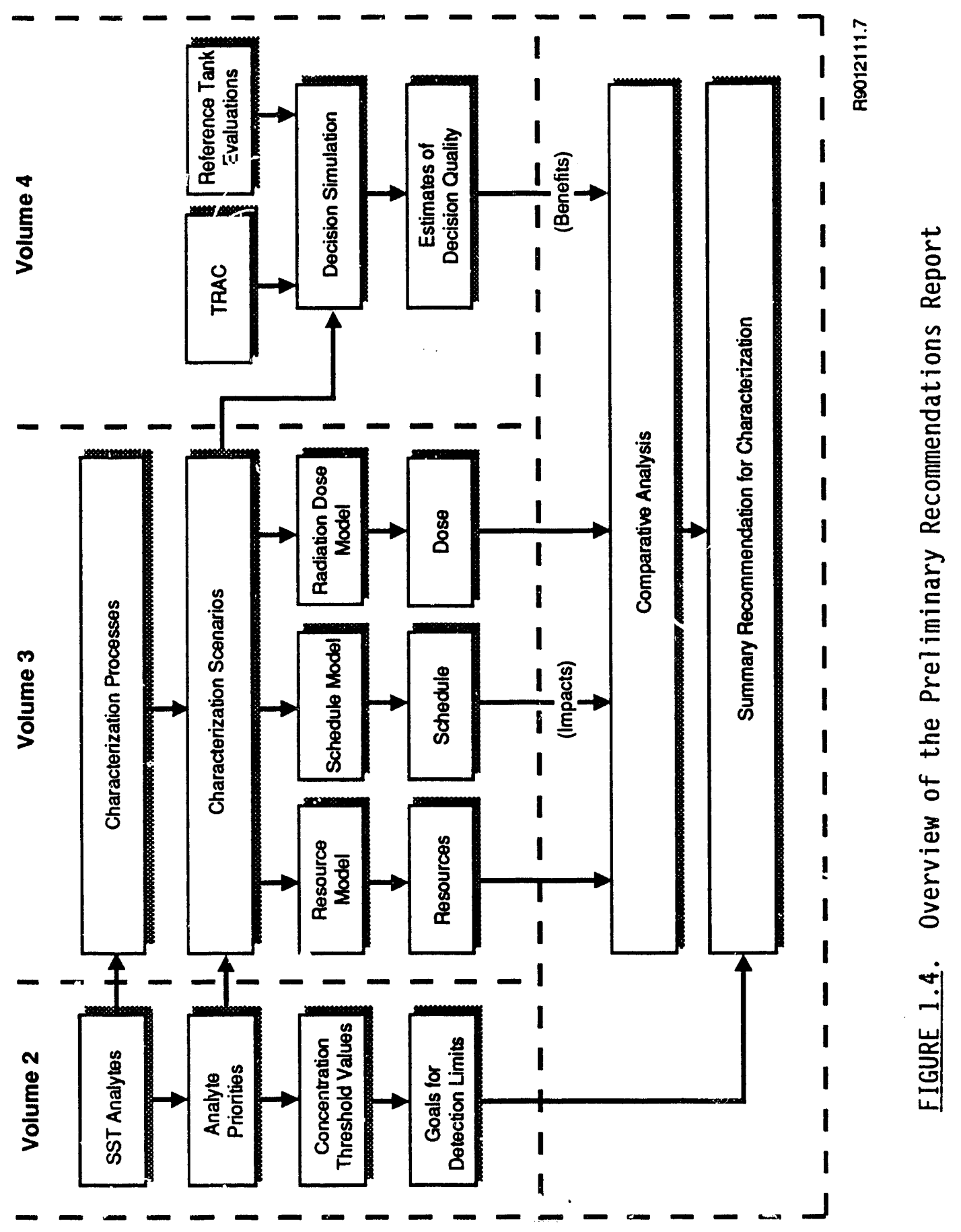




\subsection{OVERVIEW OF APPROACH}

The purpose of this analysis is to provide the SST Waste Characterization Plan (WCP) with a preliminary identification of significant analytes and detection limit goals (DLGs) based on public health impact calculations and regulatory guidelines. This analysis will assist in designing the test program for tanks in Phase IC characterization. These results are prelimiriary and are expected to change as new data are received; this entire process is iterative and will continue to evolve because of the testing, evaluating, and modifying design of the program. This chapter provides a brief description of the approach taken in this report.

\subsection{DIFFERENT METHODS OF RANKING ANALYTES}

The closure decisions (i.e., remediation decisions) for the SSTs at the Hanford Site are expected to be heavily based upon health risk assessments. This does not mean that the regulatory requirements that pertain to radionuclide and hazardous waste can be ignored. To accommodate both health risk assessment and regulatory concerns and to keep the amount of work within cost and schedule, the large number of SST analytes need to be ranked according to importance. This ranking of analytes allows the waste characterization process to concentrate on the most significant analytes while considering all analytes in general.

Three ranking methods were developed to assist in ranking the SST analytes by health risk and regulatory criteria. All three methods used SST analyte concentrations estimates from the TRAC code as input. Although the TRAC ccuie does not accurately estimate tank inventories well enough to characterize each SST for closure decisions, it was assumed that the TRAC information could be used as input for preliminary ranking of SST analytes. The SST analyte rankings are based on tank farm groups (described in Section 1.1) instead of individual tanks; therefore, they were not required to be as accurate as an estimate of an individual tank inventory would need to be.

The first ranking method, called the Long-Term Release Risk (LTRR) method, uses an integrated health risk model for ranking analytes based on 
maximum individual health risk to the public. The risk-based model used is the Multimedia Environmental Pollutant Assessment System (MEPAS). The MEPAS code is a physics-based system that inputs source term data and evaluates the potential health impact of analytes by simulating transport through the specified media and then computing human health exposures at the receptors. The MEPAS code is described in Whelan et al. (1987), Droppo et al. (1989a,b,c), Buck, Hoopes, and Friedrichs (1989), and Doctor, Miley, and Cowan (1990). Appendix A provides a brief description of the MEPAS code and its application for this analysis.

DOE conducted an environmental survey to identify problems at their facilities across the country (DOE 1988). PNL developed the Multimedia Environmental Pollutant Assessment System (MEPAS) code to rank the over 400 different environmental problems from 36 DOE facilities, and the results were used as input to a jucigmental phase for the final overall ranking for formulating corrective actions (Droppo et al. 1990). Testing the MEPAS code has been documented in Whelan et a1. (1989).

The LTRR ranking method modeled six tank farm groups as defined by six different geologic settings (as discussed in Section 1.1). It was assumed that there was one large tank, containing the whole tank farm group's inventory, that was breached in an unspecified way to allow water to leach all the inventory (over a certain time period) into the underlying unsaturated sediments. The release rate of the SST waste was solubility limited, and the transport through the unsaturated and saturated sediments was controlled by adsorption coefficients $\left(K_{d}\right)$. The exposure scenario assumed a farm with a hypothetical wel1 $50 \mathrm{~m}$ from the source of contamination and a family drinking the contaminated water from the well and consuming the food that is irrigated with contaminated water from the we11. For more details on the release, transport, and exposure scenarios used in the LTRR method, refer to Droppo et al. (1991). The analytes are ranked by comparing their maximum individual health risk with that of the others within the tank farm group. Carcinogen and noncarcinogen risks are ranked separately.

The second ranking method is the Short-Term Intruder Risk (STIR) method. This method uses three generic intruder scenarios developed by the U.S. 
Nuclear Regulatory Commission (NRC) to simulate potential contamination of individuals in the future if they inadvertently became exposed to SST waste. The three generic intruder scenarios are the intruder-construction, intruderdiscovery, and intruder-agriculture scenarios (NRC 1981a,b, 1982, 1986).

The first two intruder scenarios are dominated by inhalation and direct exposure to contaminated surface soil. The third scenario, the intruderagriculture scenario, is the most plausible case for SST waste. This scenario assumes that at some future time (assuming loss of institutional control), individuals could establish a home on SST-contaminated soil and begin farming. This scenario assumes that the concentration of analytes in the specific tank farm group has contaminated the surface soil. Ingestion, inhalation, and direct radiological exposure to contaminated surface soils are included in this scenario. This ranking method assumes direct exposure to the SST waste as opposed to the LTRR method that computes release, transport, and exposure to contamination through the groundwater.

A ranking of SST analytes is obtained from the STIR method by computing a toxicity index, which is the ratio of the analyte concentration for the tank farm group given by the TRAC code to a reference toxicity parameter. The reference toxicity parameter for each SST analyte depends on the exposure route (ingestion, inhalation, or direct radiological exposure) and constituent type (carcinogenic radionuclide, carcinogenic hazardous, or noncarcinogenic hazardous waste). More details on the reference toxicity parameter and indexes can be found in Section 3.2.1. The analyte toxicity indexes are converted to a percentage of the reference toxicity parameter and these percentages are used to rank the SST analytes.

The third ranking method used in this analysis is called the Waste Classification (WC) method. This method uses concentration guidelines for nearsurface disposal from NRC and Ecology for radioactive and hazardous waste, respectively, to generate a ranking of SST analytes. The NRC's guidelines are based on "Land Disposal of Low-level Radioactive Waste" (10 CFR 61); Ecology's guidelines are based on WAC 173-303-084 (Washington State 1987) and are primarily designed for determining whether a waste is "dangerous" or "extremely hazardous." 
The low-level radioactive waste classification from NRC gi idelines is divided into long- and short-lived radionuclides. Waste classification values presented in Table B.l of Appendix B are provided as guide?ines for classifying radioactive waste for specific waste disposal. The waste can be classified is either A, B, C, or greater than class C (GTCC) waste. The ranking of SST analytes is computed by comparing the percent ratio of TRAC concentration for a tank farm group with the WC value.

The Ecology WC guidelines use an equivalent concentration, which is computed for compounds in the waste using the National Institute of Occupational Safety and Health (NIOSH) toxicity data (NIOSH 1987). Unfortunately, the SST ranking needs to be for analytes (i.e., $\mathrm{CN}, \mathrm{Cl}, \mathrm{Na}, \mathrm{Fe}, \mathrm{NO}_{3}$ ) rather than compounds (i.e., $\mathrm{NaCl}, \mathrm{Fe}(\mathrm{CN})_{6}, \mathrm{NaNO}_{3}$ ), because the analytical analysis conducted for the WCP is based on analyte data, not compound data. An alternate NIOSH toxicity classification had to be developed to assign NIOSH toxicity data to analytes. A description of this alternate classification is provided in Appendix B. The ranking of SST analytes is computed using a form of the Toxicity Equivalency Concentration (TEC) relationship as described in WAC-173-303-084 (Washington State 1987).

\subsection{SELECTION OF ANALYTE PRIORITIES}

An important recommendation and preliminary $D Q O$ presented in this volume is the list of priority SST analytes that should be measured to provide information in support of closure decisions. The initial list of SST analytes to be considered is given in Table 2.1 (analytes that are underlined did not have tank inventories). This list was developed through a series of evaluations and considerations. Past characterization efforts for SSTs have emphasized radioactive wastes; 68 radionuclides were identified in the TRAC program. An evaluation of these isotopes based on regulatory and earlier assessments reduced the number of important radionuclides to 42 for this analysis. Several radionuclides were added because TRAC indicated they were in the tanks; therefore, 50 radionuclides were considered. In the process of tracking radionuclides, the TRAC program provided estimates of inventories for some nonradioactive compounds. A comprehensive 1 is $i$ of about 300 nonradioactive 


\section{TABLE 2.1. List of Analytes of Potential Concern}

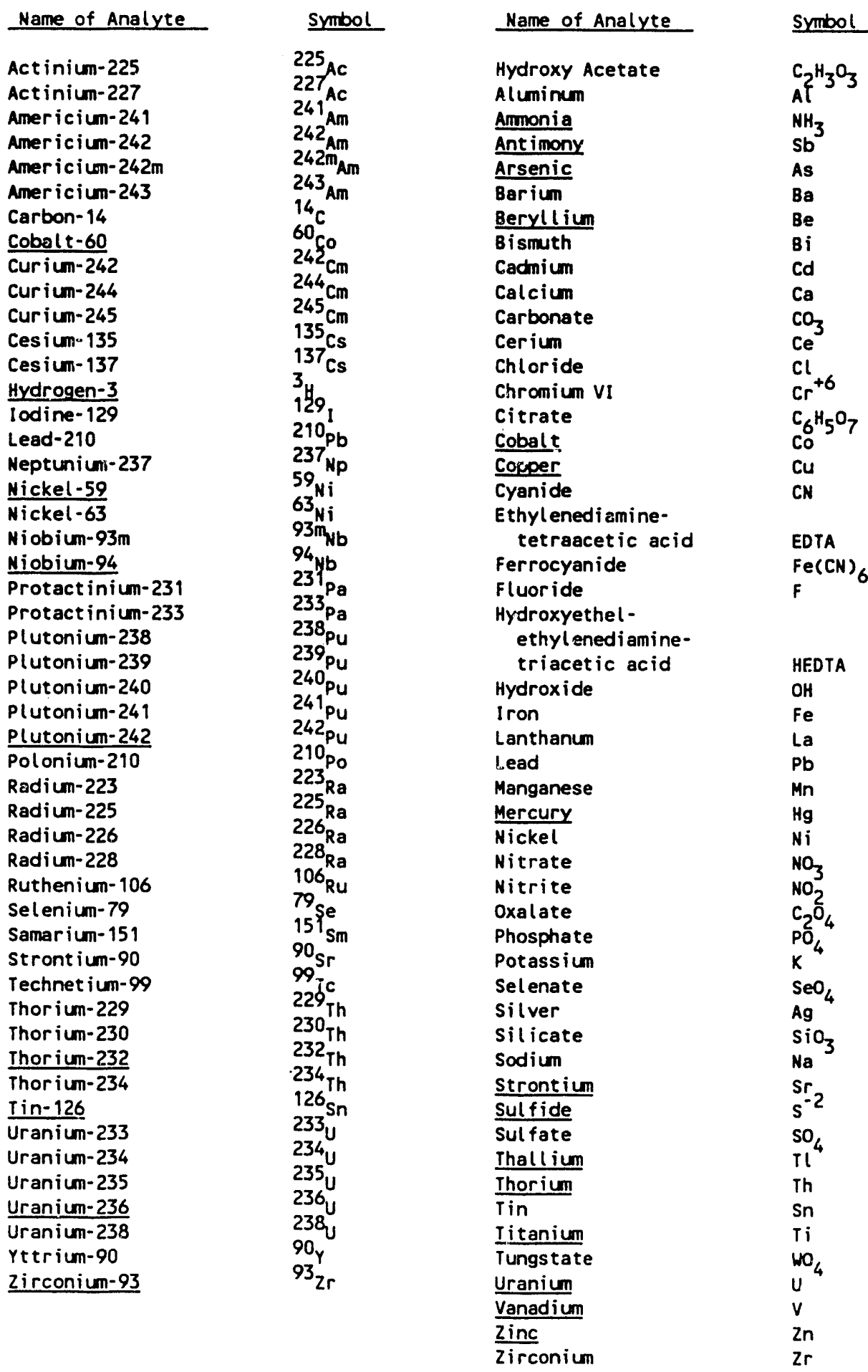

Underlined analytes do not have tank inventory estimates. 
compounds that may be in SSTs was identified by Klem (1988). This list is based on compounds that were used in Hanford production plants and support operations. A shorter 1 ist of 100 chemical compounds of regulatory importance is listed in Winters et al. (1989); it was developed from the Klem list using an approach developed by Keller et a1. (1989). A number of these compounds were not considered in this analysis because they were thought not to exist in that particular molecular structure in the high $\mathrm{pH}$ and high levels of radiation in the SSTs. The final list used for this analysis contains 50 analytes that can be combined to form the 100 chemical compounds of interest.

Of these 100 chemical and radionuclide analytes, 24 do not have tank inventory data available and therefore could not be ranked. These analytes are 1 isied in Table 2.2.

It is not expected that these analytes are in large quantities in the SSTs (especially the radionuclides) because they were not included in historical SST information such as TRAC output. For the analyte ranking and

TABLE 2.2. List of SST Anatytes Without Tank Inventories

\begin{tabular}{cc} 
Radionuclides & Chemicals \\
\hline${ }^{60} \mathrm{Co}$ & $\mathrm{As}$ \\
${ }^{3} \mathrm{H}$ & $\mathrm{Be}$ \\
${ }^{94} \mathrm{Nb}$ & $\mathrm{Co}$ \\
${ }^{59} \mathrm{Ni}$ & $\mathrm{Cu}$ \\
${ }^{242} \mathrm{Pu}^{(\mathrm{a})}$ & $\mathrm{Hg}$ \\
${ }^{126} \mathrm{Sn}$ & $\mathrm{NH}_{3}$ \\
${ }^{232} \mathrm{Th}$ & $\mathrm{S}^{-2}$ \\
${ }^{236} \mathrm{U}$ & $\mathrm{Sb}$ \\
${ }^{93} \mathrm{Zr}$ & $\mathrm{Sr}$ \\
& $\mathrm{Th}$ \\
& $\mathrm{Ti}$ \\
& $\mathrm{Tl}$ \\
& $\mathrm{U}^{(\mathrm{a})}$ \\
& $\mathrm{V}$ \\
& $\mathrm{Zn}$
\end{tabular}

(a) Could have been estimated from total $\mathrm{Pu}$ and $\mathrm{U}$, but were not. 
priority work, these analytes could not be evaluated because tank inventories are required for each analyte. They were $\mathrm{placed}$ in a separate group and identified for future analysis. For the concentration threshold (CT) and DLG calculations, these analytes were included if exposure data were available.

These 100 SST analytes were prioritized by using the three ranking methods described in Section 2.1 and were established by categorizing the ranked analytes into four types: Type I, Type II, Type III, ani Unranked. Types I and II, which are of most interest because of their high risk potential, were further subdivided into two categories each (Types IA and IB; Types IIA and IIB) to provide a more detailed picture. Type I analytes have the greatest potential for significant public health impacts and are estimated to provide at 7 east $99 \%$ of the cumulative health risk. Type II analytes are estimated to have little significant potential for public health impacts, having been estimated to contribute no more than $0.99 \%$ of the cumulative health risks.

Type I and Type II analytes, therefore, are estimated to contribute a combined total of at least $99.99 \%$ of the cumulative health risks. By comparison, the Type III analytes have no significant potential for public health impacts, as they are estimated to contribute less than $0.01 \%$ of cumulative health risk for a tank farm group. The Unranked analytes (1isted in Table 2.2) could not be ranked because of lack of tank inventory data. These analytes are not expected to contribute to the total risk of the tanks. Chapter 3.0 provides a detailed description of the process of prioritizing SST analytes.

\subsection{DETERMINATION OF CONCENTRATION THRESHOLD VALUES}

Another important concept this volume provides to the WCP is the CT that can be used to define the significance of SST analytes when analyzing for closure decisions based on health-impact criteria. Specifically, the CT value for an analyte is defined in this analysis to be the concentration at which the analyte would contribute $1 \%$ of the cumulative risk or waste class of the tank farm group. Significance of SST analytes is defined as whether an analyte contributes more than a "critical" level to the public health risk. 
This "critical" level for an analyte in this analysis is $1 \%$ of the cumulative risk or waste class of the tank farm group. That is, if an analyte contributes more than $1 \%$ of the cumulative risk or waste class of the tank farm group, it is considered significant.

The CT concept can be used to develop DLGs for each analyte (i.e., DQO) and these can be compared with current analytical detection limits ( $A D L S$ ). If the $A D L$ is greater than the DLG, the method is considered suspect and an improved procedure may be required.

The CT concept can be applied by using the three different ranking methods discussed in Section 2.1. For the LTRR method, CT values can be computed using the MEPAS model and are based on health risk. For the STIR and the WC methods, the CT values can be computed based on toxicity data and waste class criteria. Chapter 4.0 provides a detailed description of the CT computations and assumptions.

\subsection{APPLICATION OF THE CONCENTRATION THRESHOLD CONCEPT}

Analytical detection limits should be set for Phase IC Characterization such that 1) those analytes that provide a significant contribution to a closure decision are identified, and 2) the other analytes are confirmed to not be present in significant concentrations. The minimum CT values (most restrictive), based on the three different ranking methods, were used as the first estimate of significance for each analyte. In addition, these most restrictive CTs were used to define DLGs for the analytical effort of the WCP. The uncertainty associated with ADLs is estimated to be about a factor of 10 . Greater uncertainty may be associated with the LTTR CT values than with the STIR and WC CT values. Long-Term Release Risk CT values are currently judged to be accurate within approximately a factor of 10 based on opinions from the model developers and a sensitivity study conducted on the MEPAS model (Doctor, Miley, and Cowan 1990). This gave the LTRR method a factor of 100 uncertainty to defir: DLGs. The other two methods of computing CT values are based on toxicity.information and WC criteria and are used as if no uncertainty existed; therefore, their CT-to-DLG factor is 10 . 
Using the CT concept and the estimates of uncertainty of these CT values, DLGs can be estimated. The accuracy of inventory estimates for significant analytes must be greater than that for insignificant analytes (Type III analytes). Currently, a proposed DLG for an SST analyte using the LTRR method is defined as two orders-of-magnitude less than the most restrictive CT value. The proposed DLG for an SST analyte using STIR and WC methods is defined as one order-of-magnitude less than the most restrictive CT value.

In the future, DLGs should be rigorously determined using statistical methods to provide reasonable confidence that the true mean concentration value is below the $C T$. The new proposed DLGs could then be compared with the current $A D L$ values to assess if analytical methods were accurate enough and procedures precise enough. It is important to note that DLGs become important only if a decision cannot be made with existing ADLs. More detail on the determination of the DLGs and their comparison with ADLs and 241-B-110 TRAC and measured values is provided in Chapter 4.0. 


\subsection{SINGLE-SHELL TANK ANALYTE RANKING ANALYSIS}

One of the data quality objectives (CQOs) that can optimize the waste characterization is determining the most important analytes based on risk to public health. To accomplish this, analytes must be ranked or prioritized. The bases for ranking analytes in this analysis are site-specific chronic risk, intruder risk, and regulatory concerns. This chapter describes the methods used to prioritize the SST analytes [Long-Term Release Risk (LTRR), Short-Term Intruder Risk (STIR), and Waste Classification (WC)] and presents the resulting rankings.

\subsection{LONG-TERM RELEASE RISK RANKING METHOD}

Long-term risk concerns are based on potential health impacts to the public over a time period greater than an average single lifetime (70 years) using site- and waste-specific data. Long-term risks include health impacts on current and future generations. For the SST Waste Characterization PIan (WCP) effort, a time period of 10,000 years was used for the groundwater analysis because the arrival of contaminants in the soil at a particular receptor may be delayed due to solubility-controlled releases and sorption and desorption of analytes to the soil. The LTRR ranking method considers release, transport, and toxicity parameters in computing potential risk indexes that can be used to rank analytes according to their computed public health impacts.

\subsubsection{Long-Term Release Risk Ranking Scenario Definition}

As discussed in Chapter 2.0, the LTRR method is based on the MEPAS code. The mathematical formulations of the MEPAS code are documented in whelan et a1. (1987) and Droppo et a1. (1989a). Although the MEPAS code considers atmospheric, groundwater, surface water, and overland releases as well as all major exposure pathways, the LTRR scenario is based on a tank leaking into the groundwater. Therefore, only the groundwater transport and related exposure components were used for this analysis.

A risk-based analysis was performed with the MEPAS code to provide a relative ranking of analytes of concern in the SST waste at the Hanford Site 
based on tank farm groups (as defined in Section 1.1). A risk index was computed for each analyte and is based on the individual dose computed from the maximum lifetime (70 year) water concentration simulated over the modeling period. The risk index formulation varied depending on whether the analyte was a carcinogen or noncarcinogen. Appendix A provides the risk index formulations.

The source terms used to compute the risk indexes are based on a solubility-controlled release of tank farm group inventories obtained from a computer program called TRAC. The waste volume is assumed to be the accumulation of all the wastes associated with the SSTs in the tank farm group. For each tank farm group, the total waste volume is assumed to be contained in a large underground tank with completely permeable walls. If an analyte did not have tank inventory data available, it was not ranked and was placed in a separate group (Table 2.2).

The solubility-controlled release is based on infiltrating water contacting the waste form and carrying analytes away from the source at their maximum solution concentrations. Reliable solubility limits for radionuclides were not available, so they were based on a congruent release method. The congruent release method assumes that the release of all radionuclide analytes is controlled by a major, relatively soluble analyte. This method is a relatively standard approach to use when detailed information is not available on the solubility of many of the analytes. The major release analyte was assumed to be sodium nitrate $\left(\mathrm{NaNO}_{3}\right)$. Solubility limit values for chemicals were obtained from previous SST studies (Weiss 1986) and literature (Serne and Wood 1990; CRC 1988; Schultz 1978).

The transport of SST analytes was simulated with the groundwater component of the MEPAS code. The waste is assumed to migrate through partially saturated zones and a saturated zone to a hypothetical well $50 \mathrm{~m}$ downgradient of the tank farm group. Site-specific climatological data for the Hanford Site were used to determine the partially saturated zone recharge rates. A sensitivity analysis was done to test the effects of the recharge rate on the results (Droppo et a1. 1991). Recharge rates vary from 0.5 to $10.0 \mathrm{~cm} / \mathrm{yr}$ 
$(1.0 \mathrm{~cm} / \mathrm{yr}$ is the closest to a mean value at the Hanford Site). To be conservative (assuming some ground and gravel cover), $10 \mathrm{~cm} / \mathrm{yr}$ was used for SSTs. The specific transport media were defined by the geologic setting associated with the tank farm group as determined by Price and Fecht (1976a-d), Fecht and Price (1977a-1), and Tallman et al. (1979). The groundwater transport model used site-specific hydrologic information and contaminant-specific adsorption coefficients $\left(K_{d}\right)$ to quantify transport. The hydrologic and adsorption properties combine to determine the concentrations at the receptor well.

The exposure scenario used in this analysis assumed that a resident obtained all drinking and irrigation water from the well $50 \mathrm{~m}$ from the tank farm group. The exposure routes were ingestion, inhalation, and direct contact; doses were computed for 70-year increments over the 10,000-year modeling period for a $70-\mathrm{kg}$ person. The risk indexes were computed based on standard EPA guidance (EPA 1989a) for chemicals and on Buhl and Hansen (1984) and NAS (1990) for radionuclides. All the release, transport, and toxicity data used to compute these risk indexes were taken from Droppo et al. (1991).

The LTRR ranking process is made up of three major components, source term, transport, and exposure. The source term is the assumed release rate of analytes from the SST. It is based on the solubility limit of the analyte (radionuclide solubility limits were based on $\mathrm{NaNO}_{3}$ values [congruent release method]) and the TRAC inventory data. Transport is the interaction among geology, hydrology, and analyte movement through the groundwater system (partially saturated and saturated zones). Exposure is based on potential health effects from individual analytes and is associated with exposure scenarios. When these components are combined, the analytes can be ranked based on potential risk to public health. Figure 3.1 illustrates the ranking of SST analytes using the LTRR ranking method.

Risk indexes were computed for carcinogens and noncarcinogens separately because of their different health effects. Carcinogenic analytes are those that are known or suspected to cause or induce cancer and include radionuclides and hazardous chemicals. Noncarcinogenic analytes are known or suspected to cause some type of health effect (ranging from irritation of the 


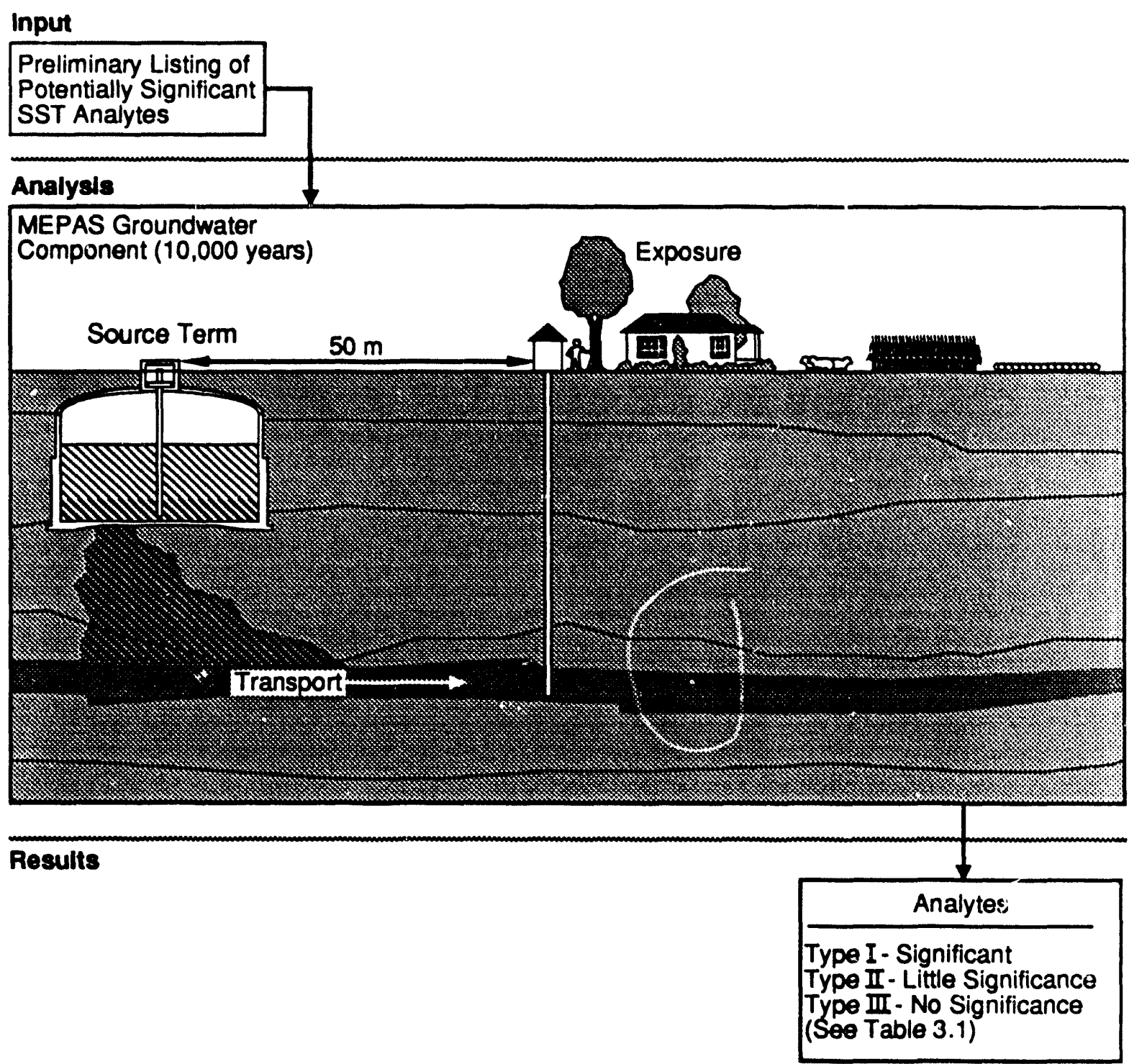

R9012111.8

FIGURE 3.1. The Single-Shel1 Tank Analyte Ranking Process Using the Long-Term Release Risk Ranking Method

eyes to destruction of organ tissue). All radionuclides in this analysis and arsenic (As) were assumed to be carcinogens for the exposure calculations. All nonradioactive chemicals in SST waste, except arsenic, were defired by $E P A^{\prime} s$ definition as noncarcinogens.

It is important not to use the risk indexes in this report as true estimates of the risk from the analytes within SSTs. Instead, these indexes are being used to provide a ranking of a large number of analytes in a consistent 
manner. It is also important not to compare carcinogen and noncarcincgen risk indexes because they are based on different health effects. In the future, comparisons of carcinogens and norcarcinogens may be required to make closure decisions on SSTS.

The risk indexes for each SST analyte were computed for a given tank farm group and were summed to create a cumulative risk index for carcinogens and noncarcinogens. This cumulative risk index was divided into each individual risk index and converted to a percentage as shown in Equation 3.1.

$$
\text { percent cumulative risk }=-\frac{\text { analyte risk index }}{\text { cumulative risk index }} * \text { ijo }
$$

These percintages represent the contribution of each analyte to the total risk of the tank farm group. The results of analyte rankings for each tank farm group are presented in Appendix A. Ethylenediaminetetraacetic acid (EDTA) ranked as the most important noncarcinogeiric analyte because of its large inventory as indicated by the TRAC code (EDTA has a relatively low toxicitiy value and is highly mobile. However, it is thought that EDTA is not in its original form because of the high $\mathrm{pH}$ and high radiation in the tanks. The uranium isotopes $\left({ }^{233} \mathrm{U},{ }^{234} \mathrm{U},{ }^{235} \mathrm{U}\right.$, and $\left.{ }^{238} \mathrm{U}\right)$ were ranked as some of the most important carcinogenic analytes because they were modeled as being quite mobile in the environment (assumed to be present as soluble uranyl carbonate species), resulting in conservative estimates of risk (i.e., higher risk than may actualiy be the case). The large uncertainties associated with the input data for EDTA and the uranium isotopes may have caused them to be ranked high, but these risk indexes were not included in the cumulative risk index, thereby allowing even more conservatism in selecting important analytes.

Twenty-four analytes were not ranked or included in the cumulative risk index calculation because tank inventories were not available (Table 2.2). However, because these analytes are of regulatory concern to the state of Washington, they were included in the list of SST analytes as a separate group of Unranked analytes. Based on expert judgment, these unranked analytes are not expected to be present in significant quantities in the SSTs and therefora 
would not influence the cumulative risk calculations for tanks or tank farm groups (Uranium metal may be the exception). Future efforts will be required to verify these assumptions.

\subsubsection{Long-Term Release Risk Ranking Scenario Results}

The ranking of analytes in the SST waste for all six tank farm groups for the LTRR ranking scenario is summarized in Table 3.1. This table 1ists the analytes in seven general gruups based on their relative contribution to the overall risk for all tank farm groups. The Type I and II analytes are subdivided into two groups (Type I-A and I-B and Type II-A and II-B) to provide more detail.

TABLE 3.1. Carcinogen Analyte Ranking Based on Long-Term Release Risk(a)

\begin{tabular}{|c|c|c|c|c|c|c|}
\hline Type I-A & Type I-B & Type II-A & Type II-B & \multicolumn{2}{|c|}{ Type III } & Unranked \\
\hline${ }^{238} \mathrm{U}$ & $235 \mathrm{U}$ & $93 \mathrm{~m}_{\mathrm{Nb}}$ & ${ }^{234} \mathrm{U}$ & ${ }^{225} \mathrm{AC}$ & ${ }^{233} \mathrm{~Pa}$ & As \\
\hline${ }^{99} \mathrm{Tc}$ & ${ }^{242 m} A \pi^{(b)}$ & ${ }^{238} \mathrm{Pu}^{(b)}$ & ${ }^{241} A \mathrm{~m}^{(b)}$ & ${ }^{227} \mathrm{AC}$ & ${ }^{223} \mathrm{Ra}$ & ${ }^{60} \mathrm{Co}$ \\
\hline${ }^{14} \mathrm{C}$ & ${ }^{240} \mathrm{Pu}{ }^{(b)}$ & ${ }^{239} \mathrm{Pu}^{(b)}$ & ${ }^{242} \mathrm{Cm}^{(b)}$ & ${ }^{242} \mathrm{Am}$ & ${ }^{225} \mathrm{Ra}$ & ${ }^{3} \mathrm{H}$ \\
\hline $129_{i}$ & & & ${ }^{237} \cdot N p^{(b)}$ & ${ }^{243} \mathrm{Am}$ & ${ }^{226} \mathrm{Ra}$ & ${ }^{94} \mathrm{Nb}$ \\
\hline & & & ${ }^{233} U$ & ${ }^{244} \mathrm{Cm}$ & ${ }^{228} \mathrm{Ra}$ & ${ }^{59} \mathrm{Ni}$ \\
\hline & & & & ${ }^{245} \mathrm{Cm}$ & ${ }^{166} \mathrm{Ru}$ & ${ }^{242} \mathrm{Pu}$ \\
\hline & & & & ${ }^{135} \mathrm{Cs}$ & ${ }^{79} \mathrm{Se}$ & ${ }^{126} \mathrm{Sn}$ \\
\hline & & & & ${ }^{137} \mathrm{Cs}$ & ${ }^{151} \mathrm{Sm}$ & ${ }^{232} \mathrm{Th}$ \\
\hline & & & & ${ }^{210} \mathrm{~Pb}$ & ${ }^{99} \mathrm{Sr}$ & ${ }^{236} U$ \\
\hline & & & & ${ }^{63} \mathrm{Ni}$ & ${ }^{229} \mathrm{Th}$ & ${ }^{93} 7 r$ \\
\hline & & & & ${ }^{241} p_{u}$ & ${ }^{230} \mathrm{Th}$ & \\
\hline & & & & ${ }^{210} \mathrm{p}_{0}$ & ${ }^{234} \mathrm{Th}$ & \\
\hline & & & & ${ }^{231} \mathrm{~Pa}$ & $96 y$ & \\
\hline
\end{tabular}

(a) Type I-A analytes include 0.00 to $90.00 \%$ of cumulative risk. Type I-B analytes include 90.00 to $99.00 \%$ of cumulative risk. Type II-A analytes include 99.00 to $99.90 \%$ of cumulative risk. Type II-B analytes include 99.90 to $99.99 \%$ of cumulative risk. Carcinogenic Type analytes in this list are based on percent risk excluding ${ }^{238} U,{ }^{235} U,{ }^{234} U$, and ${ }^{233} U$ in the cumulative risk.

(b) Indicates the analyte priority is because of daughter product risk. 
The analyte types were defined by dividing the cumulative risk index percentages into general groups. Type I-A analytes account for $90 \%$ of the cumulative risk index, Type I-B analytes account for the next $9 \%$ (90\% to $99 \%)$, Type II-A analytes account for the next $0.9 \%$ (99\% to $99.9 \%)$, Type II-B analytes account for the next $0.09 \%$ (99.9\% to $99.99 \%$ ), and Type III analytes account for less than $0.01 \%$ of the cumulative risk index. Each analyte was assigned a group based on its highest ranking for all of the tank farm groups (i.e., if an analyte is a Type I-B in one tank farm group and it is a Type III in the other five tank farm groups, it will be assigned to the Type I-B group). The percentages associated with the risk indexes for the analytes are provided in Tables A.1 through A.6 in Appendix A.

The 24 analytes in the unranked group in Tables 3.1 and 3.2 were not ranked because tank inventories were not available. For seven radionuclides, a11 of which are transuranics, the risk index is based on a decay product rather than on the parent analyte. The additional analysis used for decay products is described in detail in Appendix $C$.

As shown in Tables 3.1 and 3.2, only $8 \%$ ( 8 out of 100) of the SST analytes were classified as Type I-A based on the LTRR ranking scenario. Only $5 \%$ ( 5 out of 100) of the analytes that were Type I-B, $4 \%$ ( 4 out of 100 ) were Type II-A, and 10\% (10 out of 100) were Type II-B. This 1eaves $54 \%$ (54 out of 100 ) of the analytes that were ranked as Type III and $24 \%$ (24 out of 100) of the analytes that were unranked based on the LTRR ranking scenario. Most of the Type III analytes were ranked as insignificant risk contributors because of their lack of mobility in the groundwater system (high adsorption coefficient $\left[K_{d}\right]$ ) or their limited release rate (solubility limited).

\subsection{SHORT-TERM INTRUDER RISK RANKING SCENARIO}

The STIR ranking method was used to assist in determining an analyte's potential health impact when there is the possibility of contact with the hazardous or radioactive analytes. Unlike the LTRR method that considers risk out to 10,000 years, the STIR method considers chronic intruder risk for the waste in its current state. Contact with an analyte can occur through several 
TABLE 3.2. Noncarcinogen Analyte Ranking Based on Long-Term Release Risk(a)

\begin{tabular}{|c|c|c|c|c|c|c|}
\hline Type I-A & Type I-B & Type II-A & Type II-B & Type & & Unranked \\
\hline EDTA & $\mathrm{CN}$ & $\mathrm{Na}$ & $\mathrm{SO}_{4}$ & $\mathrm{C}_{2} \mathrm{H}_{3} \mathrm{O}_{3}$ & La & $\mathrm{Be}$ \\
\hline $\mathrm{NO}_{2}$ & $\mathrm{Cr}^{+6}$ & & & Al & $\mathrm{Pb}$ & Co \\
\hline $\mathrm{NO}_{3}$ & & & & $\mathrm{Ba}$ & Mn & $\mathrm{Cu}$ \\
\hline $\mathrm{F}$ & & & & $\mathrm{Bi}$ & $\mathrm{Ni}$ & $\mathrm{Hg}$ \\
\hline & & & & $\mathrm{Cd}$ & $\mathrm{C}_{2} \mathrm{O}_{4}$ & $\mathrm{NH}_{3}$ \\
\hline & & & & $\mathrm{Ca}$ & $\mathrm{PO}_{4}$ & $\mathrm{Sb}$ \\
\hline & & & & $\mathrm{CO}_{3}$ & K & $s r$ \\
\hline & & & & Ce & $\mathrm{SeO}_{4}$ & $\mathrm{~s}^{-2}$ \\
\hline & & & & C1 & $\mathrm{Ag}$ & Th \\
\hline & & & & $\mathrm{C}_{6} \mathrm{H}_{5} \mathrm{O}_{7}$ & $\mathrm{SiO}_{3}$ & T1 \\
\hline & & & & $\mathrm{Fe}$ & Sn & $\mathrm{Ti}$ \\
\hline & & & & $\mathrm{Fe}(\mathrm{CN})_{6}$ & $\mathrm{WO}_{4}$ & U \\
\hline & & & & HEDTA & $\mathrm{Zr}$ & V \\
\hline & & & & $\mathrm{OH}$ & & $\mathrm{Zn}$ \\
\hline
\end{tabular}

(a) Type I-A analytes include 0.00 to $90.00 \%$ of cumulative risk. Type I-B analytes include 90.00 to $99.00 \%$ of cumulative risk. Type II-A analytes include 99.00 to $99.90 \%$ of cumulative risk. Type II-B analytes include 99.90 to $99.99 \%$ of cumulative risk. Noncarcinogenic Type analytes in this list are based on percent risk excluding EDTA in the cumulative risk.

exposure pathways, each having a different level of toxicity. To evaluate SST analyte ranking, intruder scenarios were included along with the associated exposure pathways to determine which analytes were of greatest toxic concern. The main consideration of the STIR evaluations are the inventory and toxicity of the analyte.

\subsubsection{Short-Term Intruder Risk Ranking Scenario Definition}

In the future, if institutional controt is lost, individuals may inadvertently become exposed to hazardous and radioactive analytes that pose a threat to human health. Intruder scenarios are designed to simulate possible contamination received by an individual under such circumstances. The NRC outlined three generic intruder scenarios: the Intruder-Construction 
Scenario, the Intruder-Discovery Scenario, and the Intruder-Agriculture Scenario (NRC 1981a,b, 1982, 1986). The first two scenarios are dominated by two exposure routes, inhalation and direct radiological exposure. Direct radiological exposure is defined as health effects caused by direct contact or nearly direct association with radioactive sources.

The third scenario, Intruder-Agriculture, considers the possibility that at some future time, people will build homes or farms on the disposal site and operate farms on the surrounding contaminated region. For this analysis, the SST analytes are assumed to have contaminated the surface soil (through excavation or some other disturbance). The exposure routes of concern with the Intruder-Agriculture scenario are ingestion, inhalation, and direct exposure.

Instead of deciding which of the three exposure routes is most important and determining how to properly weight each to determine its toxicity index value, each of the exposure routes was evaluated separately. Analytes were grouped as radionuclides or chemicals. The chemical ranking was based on ingestion and inhalation exposure routes, while radionuclides included ingestion, inhalation, and ground exposure.

Toxicity parameters and TRAC-computed concentrations were used to compute the toxicity indexes that were used to rank SST analytes. These toxicity parameters varied depending on whether the analyte was a carcinogen or noncarcinogen and on its particular exposure route. Toxicity parameters were obtained from the MEPAS database unless otherwise stated.

For ranking the noncarcinogenic analytes, the reference doses (RfDs) were used when available. The RfD is defined as the estimate of the largest amount of a noncarcinogenic analyte to which a person can be exposed without adverse health effects. The majority of RfDs 1 isted by MEPAS were obtained using EPA's Integrated Risk Information System (IRIS) documented in EPA (1989b). When IRIS values were not available, other referenced sources were used to estimate an RfD. When MEPAS did not list RfDs for certain chemicals, $L_{50}$ values were converted to RfD values using the following empirical conversion factor, which is based on a study by Layton et al. (1987):

$$
R f D=L D_{50} \cdot 4.0 \times 10^{-5}
$$


$\mathrm{LD}_{58}$ values are defined as the mean lethal dose of a chemical expected to cause death in $50 \%$ of the test animals. RfDs expressed in Equation 3.2 have units of milligrams of chemical per kilogram of person per-day for both the ingestion and inhalation exposure routes. For three chemicals, $\mathrm{Cr}^{+6}, \mathrm{Ni}$, and $\mathrm{Cd}$, cancer potency factors were used to rank the inhalation exposure route (these chemicals are noncarcinogenic for ingestion only). The cancer potency factors are expressed in units of kilogram-days per milligram (inverse of RfD units). Based on the RfDs and cancer potency factors, a means of ranking the importance of each chemical analyte was created.

A parameter called the Toxicity Index was defined for each SST analyte to be ranked. The TRAC-estimated concentrations for each tank farm group of chemical noncarcinogens and carcinogens were converted to a dose (divided by the average person's weight of $70 \mathrm{~kg}$ and a 70 -year lifetime). This dose is then divided by the RfD for noncarcinogens and multiplied by the cancer potency factor for carcinogens to obtain the toxicity index (which is dimensioniess).

Radioaccive analytes were ranked for three exposure routes: inhalation, ingestion, and direct exposure. Radiological dosimetry factors and specific activity per mass $(\mathrm{pC} i / g)$ for each radionuclide and exposure route were used to determine toxicity index. The radiological dosimetry factor value for direct exposure is expressed as a dose rate (rem/hr) per ground concentration in the surface sediments $\left(\mathrm{pCi} / \mathrm{m}^{2}\right)$. Thus, for the direct exposure case, the radiological dosimetry factor value was multiplied by the specific activity per mass of the radionuclide and divided by the tank farm area $\left(\mathrm{m}^{2}\right)$ to determine the toxicity index. This toxicity index for direct exposure is expressed in units of $\mathrm{rem} / \mathrm{hr} / \mathrm{g}$.

The radiological dosimetry factor value for inhalation and ingestion is expressed in rem $/ \mathrm{pCi}$. Therefore, for the inhalation and ingestion toxicity index, the radiological dosimetry factor value was multiplied by the TRAC estimate of radionuclide total specific activity for the tank farm group. The resulting toxicity indexes were in units of rems per gram of waste for all three exposure routes. 


\subsubsection{Short-Term Intruder Risk Ranking Scenario Results}

The rankings of analytes in the SST waste for all tank farms using the STIR ranking scenario are summarized in Tables 3.3 and 3.4. These tables categorize the analytes into general risk-based groups as was done for the LTRR method in Tables 3.1 and 3.2. The scenario with the highest toxicity

TABLE 3.3. Carcinogen Analyte Ranking Based on Short-Term Intruder Risk ${ }^{(a)}$

\begin{tabular}{|c|c|c|c|c|c|c|}
\hline Type I - A & Type I-B & Type II-A & Type II-B & \multicolumn{2}{|c|}{ Type III } & Unranked \\
\hline${ }^{241} \mathrm{Am}$ & ${ }^{240} \mathrm{Pu}$ & ${ }^{242} \mathrm{Am}$ & ${ }^{243} \mathrm{Am}$ & ${ }^{225} \mathrm{AC}$ & ${ }^{223} \mathrm{Ra}$ & As \\
\hline${ }^{137} \mathrm{Cs}$ & & ${ }^{244} \mathrm{Cm}$ & & ${ }^{227} \mathrm{AC}$ & ${ }^{225} \mathrm{Ra}$ & ${ }^{60} \mathrm{Co}$ \\
\hline${ }^{239} \mathrm{Pu}$ & & ${ }^{237} \mathrm{~Np}$ & & ${ }^{242 m} \mathrm{Am}$ & ${ }^{226} \mathrm{Ra}$ & ${ }^{3} H$ \\
\hline${ }^{90} \mathrm{Sr}$ & & ${ }^{238} \mathrm{Pu}$ & & ${ }^{14} \mathrm{C}$ & ${ }^{228} \mathrm{Ra}$ & ${ }^{94} \mathrm{Nb}$ \\
\hline${ }^{96} Y$ & & ${ }^{241} \mathrm{Pu}$ & & ${ }^{242} \mathrm{Cm}$ & ${ }^{166} \mathrm{Ru}$ & ${ }^{59} \mathrm{Ni}$ \\
\hline & & ${ }^{238} \mathrm{U}$ & & ${ }^{245} \mathrm{Cm}$ & ${ }^{79} \mathrm{Se}$ & ${ }^{242} \mathrm{Pu}$ \\
\hline & & & & ${ }^{135} \mathrm{Cs}$ & ${ }^{151} \mathrm{Sm}$ & ${ }^{126} S n^{(b)}$ \\
\hline & & & & ${ }^{129} \mathrm{I}$ & ${ }^{99} \mathrm{Te}$ & ${ }^{232} \mathrm{Th}$ \\
\hline & & & & ${ }^{210} \mathrm{~Pb}$ & ${ }^{229} \mathrm{Th}$ & ${ }^{236} U$ \\
\hline & & & & ${ }^{63} \mathrm{Ni}$ & ${ }^{230} \mathrm{Th}$ & ${ }^{93} Z{ }^{(b)}$ \\
\hline & & & & ${ }^{93 \mathrm{~m}} \mathrm{Nb}$ & ${ }^{234} \mathrm{Th}$ & \\
\hline & & & & ${ }^{210} \mathrm{Po}_{\mathrm{O}}$ & ${ }^{233} u$ & \\
\hline & & & & ${ }^{231} \mathrm{~Pa}$ & ${ }^{234} U$ & \\
\hline & & & & ${ }^{233} \mathrm{~Pa}$ & ${ }^{235} U$ & \\
\hline
\end{tabular}

(a) I-A analytes include 0.00 to $90.00 \%$ of total toxicity. Type I-B analytes include 90.00 to $99.00 \%$ of total toxicity. Type II.-A analytes include 99.00 to $99.90 \%$ of total toxicity. Type II-B analytes include 99.90 to $99.99 \%$ of total toxicity. Type III analytes include 99.99 to $100.00 \%$ of total toxicity.

(b) Indicates analyte was accidentally omitted from analysis. 
TABLE 3.4. Noncarcinogen Analyte Ranking Based on Short-Term Intruder Risk(a)

\begin{tabular}{|c|c|c|c|c|c|}
\hline Type I-A & Type I-B & Type II-A & Type II-B & Type III & Unranked \\
\hline Al & $\mathrm{Ba}$ & $\mathrm{Fe}(\mathrm{CN})_{6}$ & $\mathrm{Ca}$ & $\mathrm{C}_{2} \mathrm{H}_{3} \mathrm{O}_{3}$ & $\mathrm{Be}$ \\
\hline $\mathrm{Cr}^{+6}$ & $\mathrm{Cd}$ & $\mathrm{SiO}_{3}$ & $\mathrm{Na}$ & $\mathrm{Bi}$ & Co \\
\hline EDTA & $\mathrm{CO}_{3}$ & & & $\mathrm{Ce}$ & $\mathrm{Cu}$ \\
\hline $\mathrm{Fe}$ & $F$ & & & $\mathrm{Cl}$ & $\mathrm{Hg}$ \\
\hline Mn & HEDTA & & & $\mathrm{C}_{6} \mathrm{H}_{5} \mathrm{O}_{7}$ & $\mathrm{NH}_{3}$ \\
\hline $\mathrm{Ni}$ & $\mathrm{NO}_{3}$ & & & $\mathrm{CN}$ & $\mathrm{Sb}$ \\
\hline $\mathrm{NO}_{2}$ & $\mathrm{~Pb}$ & & & La & $S r$ \\
\hline $\mathrm{OH}$ & $\mathrm{SO}_{4}$ & & & $\mathrm{C}_{2} \mathrm{O}_{4}$ & $\mathrm{~S}^{-2}$ \\
\hline \multirow[t]{6}{*}{$\mathrm{PO}_{4}$} & $\mathrm{Zr}$ & & & K & Th \\
\hline & & & & $\mathrm{SeO}_{4}$ & T1 \\
\hline & & & & $\mathrm{Ag}$ & $\mathrm{Ti}$ \\
\hline & & & & Sn & $U$ \\
\hline & & & & $\mathrm{WO}_{4}$ & $v$ \\
\hline & & & & & $\mathrm{Zn}$ \\
\hline
\end{tabular}

(a) Type I-A analytes include 0.00 to $90.00 \%$ of cumulative risk. Type I-B analytes include 90.00 to $99.00 \%$ of cumulative risk Type II-A analytes include 99.00 to $99.90 \%$ of cumulative risk Type II-B analytes include 99.90 to $99.99 \%$ of cumulative risk Noncarcinogenic Type analytes in this list are based on percent risk excluding EDTA in the cumulative risk.

index for an analyte was used to rank the analyte as presented in Tables 3.3 and 3.4, and a diagram of the ranking process using the STIR ranking method is provided in Figure 3.2 .

In Tables 3.3 and $3.4,14 \%$ of the SST analytes are Type I-A based on the STIR ranking method, $10 \%$ of the analytes are Type I-B, $8 \%$ are Type II-A, and $3 \%$ are Type II-B. This leaves $41 \%$ of the analytes that were ranked as Type III and $24 \%$ of the analytes unranked based on the STIR ranking method.

The analytes that were ranked as Type I and II analytes by the STIR method were ranked as such based primarily on the toxicity parameter (RfD, cancer potency factor, or radiological dosimetry factor) of the analytes. If an analyte is associated with $90 \%$ of the cumulative risk for the tank farm 


\section{Input}

\section{Preliminary Listing of Potentially Significant SST Analytes}

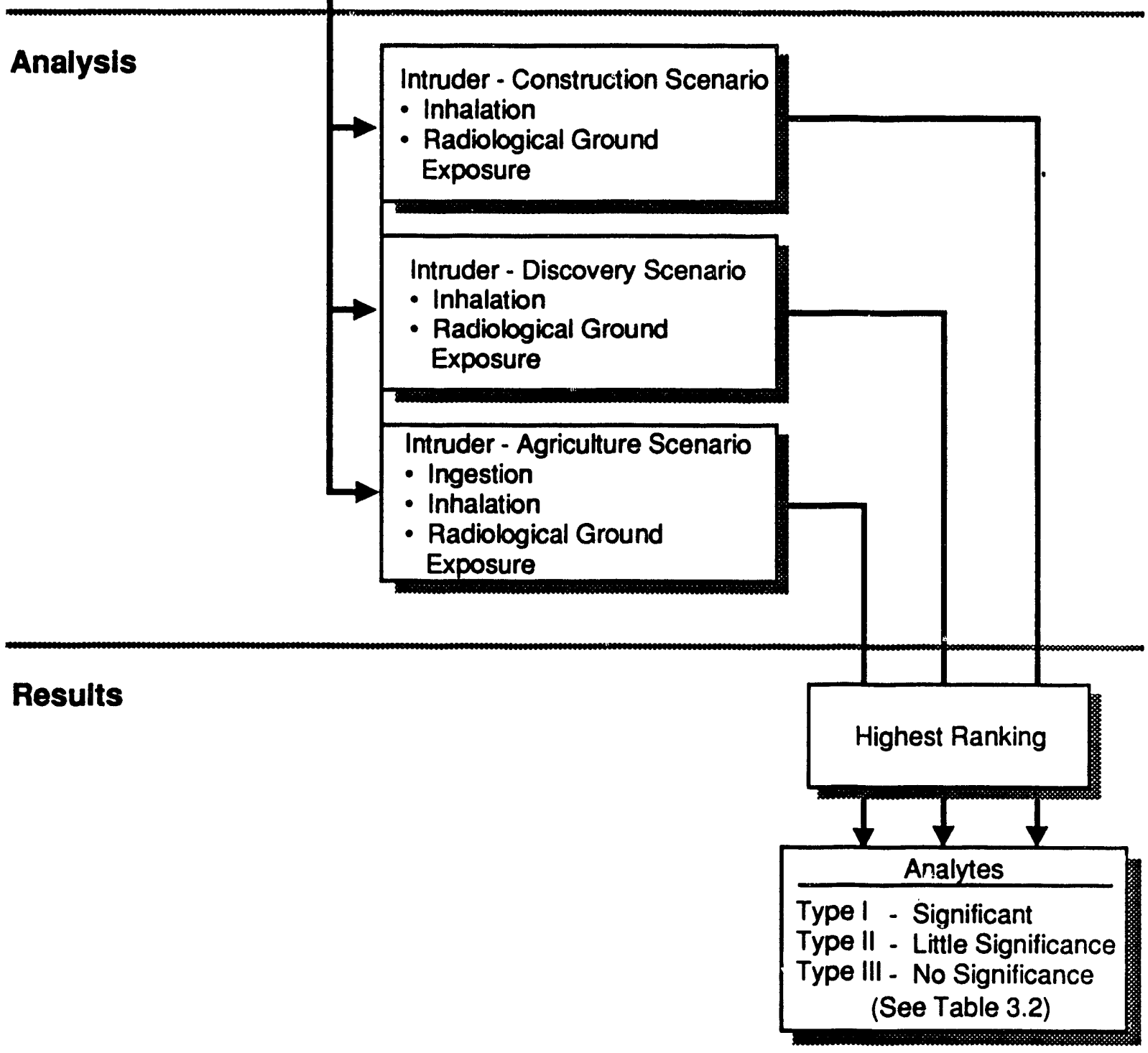

FIGURE 3.2. The Single-She1l Tank Analytes Ranking Process Using the Short-Term Release Risk Ranking Method 
group, it was ranked as a Type I-A analyte. Analytes such as ${ }^{241} \mathrm{Am},{ }^{137} \mathrm{Cs}$, ${ }^{239} \mathrm{Pu},{ }^{90} \mathrm{Sr},{ }^{96} \mathrm{Y}, \mathrm{Al}, \mathrm{Cr}^{+6}$, EDTA, $\mathrm{Fe}, \mathrm{OH}, \mathrm{Mn}, \mathrm{Ni}, \mathrm{NO}_{2}$, and $\mathrm{PO}_{4}$ are Type I-A analytes.

\subsection{WASTE CLASSIFICATION RANKING METHOD}

As a check on analyte priorities generated through the LTRR and STIR methods, an alternative ranking system was applied based on the Waste Classification (WC) systems of the NRC and the Washington State Department of Ecology (Ecology). These regulatory agencies, having responsibility for licensing/permitting the disposal of certain radioactive and chemically hazardous wastes (i.e., dangerous waste), have previously promulgated concentration guidelines for near-surface disposal. The criteria for disposal of commercially generated low-level radioactive waste are specified in the NRC's 10 CFR 61, "Land Disposal of Low-Level Radioactive Waste."

Ecology provides concentration-based guidelines in its Dangerous Waste Regulations (WAC 173-303-084). These regulations include a means of determining an equivalent concentration of toxic constituents (sum of the fractions) when a waste contains a mixture of toxic constituents (nonradioactive). This regulation includes classification of chemical waste as non-regulated, dangerous, or extremely hazardous waste (EHW).

\subsubsection{Dangerous Waste Classification Description}

The WAC 173-303-084 document is designed primarily for determining the equivalent concentration when toxic nonradioactive constituents remain as compounds in solution, and it is used as one method for assessing whether a waste is dangerous waste or EHW.

For analytes stored in the SSTs, most of the compounds dissolved in the aqueous phase ionize and remain in ionic forms. Any excess amount above their solubility limits will precipitate and form slurry or sludge in the bottom of the tanks. WAC 173-303-084 was not designed to apply to ionic species that constitute toxic analytes in the case of the SST waste. An alternate method of defining toxicity categories was developed to define a NIOSH toxicity parameter for each of the SST analytes considered in the ranking study. This 
alternate method was meant to be an estimate of the SST analyte toxicities by using reference compounds in the tanks that had toxicity data available. In the future, more accurate information on compounds associated with the SST chemical environment in the tanks will be evaluated for a more realistic approach. Values for these alternate toxicity parameters are provided in Table B.2 and a detailed description of this alternate toxicity classification is provided in Appendix $B$ of this report.

Once toxicity parameters were determined for each analyte based on the NIOSH toxicity data, a total WC index (similar to the equivalent classification concentration specified in the WAC 173-303-084) was computed for each SST farm group. The computation of the total WC index involved dividing all the analyte concentrations within a given NIOSH toxicity category by the appropriate factor provided by WAC 173-303-084 (X by $1, A$ by 10 , B by $100, C$ by 1000 , and $D$ by 10,000 ) and summing them for a given tank farm group. The total WC index is then divided into each individual analyte's concentration to determine its percent of the cumulative WC for the tank farm group. These percentages were then used to rank the analytes for the WC ranking method.

\subsubsection{Low-Level Radioactive Waste Classification Description}

The specification of the 10 CFR 61 document divides low-level radioactive waste into four classes: $A, B, C$, and greater-than-Class-C (GTCC) waste. The classification has two categories of waste: long-lived and shortlived radioactive waste. Examples of long-lived radionuclides are ${ }^{14} \mathrm{C},{ }^{99} \mathrm{Tc}$, ${ }^{129} \mathrm{I},{ }^{242} \mathrm{Cm},{ }^{241} \mathrm{Pu}$, and any alpha-emitting transuranic with a half-life greater than five years. Examples of short-lived radionuclides are ${ }^{3} \mathrm{H},{ }^{60} \mathrm{Co},{ }^{63} \mathrm{Ni}$, ${ }^{99} \mathrm{Sr},{ }^{13 i} \mathrm{Cs}$, and radionuclides with half-lives less than 5 years.

For this analysis, the class of waste in the SSTs is not important. The important aspect of the analysis is how the analyte concentrations in the SST farms groups compare using the Class $C$ calculation method for ranking analytes. Table B.1 in Appendix $B$ provides a reproduction of the long- and shortlived radionuclide tables from the 10 CFR 61 document in units appropriate for the SST analysis. The WC criteria have been converted to microcuries of analyte per gram of waste $(\mu \mathrm{C} / \mathrm{g})$ using an average bulk density of the SST sludge waste as $1.8 \mathrm{~g} / \mathrm{cm}^{3}$. 
The Class C criteria provided in Table B.l were used to compute the WC index by dividing each radionuclide concentration by the appropriate value in Table B.1. These indexes were then summed for each tank farm group to provide a total WC index for radionuclides. Each individual WC index was divided by the total WC index for the tank farm group and converted to a percentage. These percentages were used to rank the analytes.

\subsubsection{Waste Classification Ranking Method Results}

The rankings of analytes in the SST waste for all tank farms based on the WC ranking method are summarized in Tables 3.5 and 3.6 . These tables categorize the analytes into general groups for optimizing the SST characterization effort, as was done for LTRR and STIR ranking scenarios. The groups

IABLE 3.5. Carcinogen Analyte Ranking Based on Waste Classification (a)

\begin{tabular}{|c|c|c|c|c|c|c|}
\hline Type I-A & Type I-B & Iype II-A & Type II-B & \multicolumn{2}{|c|}{ Type III } & Unranked \\
\hline${ }^{241} \mathrm{Am}$ & ${ }^{238} \mathrm{Pu}$ & ${ }^{242 m} \mathrm{Am}$ & ${ }^{243} \mathrm{Am}$ & ${ }^{225} \mathrm{AC}$ & ${ }^{226} \mathrm{Ra}$ & As \\
\hline${ }^{137} \mathrm{Cs}$ & ${ }^{241} \mathrm{Pu}$ & ${ }^{244} \mathrm{Cm}$ & & ${ }^{227} \mathrm{AC}$ & ${ }^{228} \mathrm{Ra}$ & ${ }^{66} \mathrm{Co}_{0}$ \\
\hline${ }^{239} \mathrm{Pu}$ & ${ }^{14} \mathrm{C}$ & ${ }^{237} \mathrm{~Np}$ & & ${ }^{242} \mathrm{Am}$ & ${ }^{106} \mathrm{Ru}$ & ${ }^{3} \mathrm{H}$ \\
\hline${ }^{240} \mathrm{Pu}$ & ${ }^{129} \mathrm{I}$ & & & ${ }^{242} \mathrm{Cm}$ & ${ }^{79} \mathrm{Se}$ & ${ }^{94} \mathrm{Nb}$ \\
\hline${ }^{90} \mathrm{Sr}$ & ${ }^{63} \mathrm{Ni}$ & & & ${ }^{245} \mathrm{Cm}$ & ${ }^{151} \mathrm{Sm}$ & ${ }^{59} \mathrm{Ni}$ \\
\hline${ }^{99} \mathrm{Tc}$ & & & & ${ }^{135} \mathrm{Cs}$ & ${ }^{229} \mathrm{Th}$ & ${ }^{242} \mathrm{Pu}$ \\
\hline & & & & ${ }^{210} \mathrm{~Pb}$ & ${ }^{238} \mathrm{Th}$ & ${ }^{126} S n^{(b)}$ \\
\hline & & & & ${ }^{93 m_{\mathrm{mb}}}$ & ${ }^{234} \mathrm{Th}$ & ${ }^{232} \mathrm{Th}$ \\
\hline & & & & ${ }^{210} \mathrm{Po}$ & ${ }^{233} U$ & ${ }^{236} U$ \\
\hline & & & & ${ }^{231} \mathrm{~Pa}$ & ${ }^{234} U$ & ${ }^{93} \mathrm{Zr}(\mathrm{b})$ \\
\hline & & & & ${ }^{233} \mathrm{~Pa}$ & ${ }^{235} U$ & \\
\hline & & & & ${ }^{223} \mathrm{Ra}$ & ${ }^{238} U$ & \\
\hline & & & & ${ }^{225} \mathrm{Ra}$ & $90 y$ & \\
\hline
\end{tabular}

(a) Type I-A analytes include 0.00 to $90.00 \%$ of waste classification. Type I-B analytes include 90.00 to $99.00 \%$ of waste classification. Type II-A analytes include 99.00 to $99.90 \%$ of waste classification. Type II-B analytes include 99.90 to $99.99 \%$ of waste classification. Type III analytes include 99.99 to $100.00 \%$ of waste classification.

(b) Indicates analyte was accidentally omitted. 
TABLE 3.6. Noncarcinogen Analyte Ranking Based on Waste Classification(a)

\begin{tabular}{|c|c|c|c|c|c|}
\hline Type I-A & Type I-B & Type II-A & Type II -B & Type III & Unranked \\
\hline $\mathrm{Bi}$ & Al & $\mathrm{Fe}(\mathrm{CN})_{6}$ & $\mathrm{Ba}$ & $C d$ & $\mathrm{Be}$ \\
\hline $\mathrm{Cr}^{+6}$ & $\mathrm{C}_{6} \mathrm{H}_{5} \mathrm{O}_{7}$ & & $\mathrm{Ca}$ & $\mathrm{Ce}$ & Co \\
\hline $\mathrm{Fe}$ & $\mathrm{CO}_{3}$ & & $\mathrm{C}_{2} \mathrm{H}_{3} \mathrm{O}_{3}$ & $\mathrm{Cl}$ & $\mathrm{Cu}$ \\
\hline $\mathrm{OH}$ & EDTA & & K & $\mathrm{CN}$ & $\mathrm{Hg}$ \\
\hline $\mathrm{Na}$ & $F$ & & $M n$ & La & $\mathrm{NH}_{3}$ \\
\hline $\mathrm{NO}_{2}$ & HEDTA & & $\mathrm{Pb}$ & $\mathrm{C}_{2} \mathrm{O}_{4}$ & $\mathrm{Sb}$ \\
\hline \multirow[t]{8}{*}{$\mathrm{NO}_{3}$} & $\mathrm{Ni}$ & & & $\mathrm{SeO}_{4}$ & $S r$ \\
\hline & $\mathrm{PO}_{4}$ & & & $\mathrm{Ag}$ & $\mathrm{S}^{-2}$ \\
\hline & $\mathrm{SiO}_{3}$ & & & Sn & Th \\
\hline & $\mathrm{SO}_{4}$ & & & $\mathrm{WO}_{4}$ & TI \\
\hline & $\mathrm{Zr}$ & & & & $\mathrm{Ti}$ \\
\hline & & & & & $U$ \\
\hline & & & & & V \\
\hline & & & & & $\mathrm{Zn}$ \\
\hline
\end{tabular}

(a) Type I-A analytes include 0.00 to $90.00 \%$ of waste classification. Type I-B analytes include 90.00 to $99.00 \%$ of waste classification. Type II-A analytes include 99.00 to $99.90 \%$ of waste classification. Type II-B analytes include 99.90 to $99.99 \%$ of waste classification. Type III analytes include 99.99 to $100.00 \%$ of waste classification.

for this scenario are the same as were used in the other ranking scenarios so they can be compared. Figure 3.3 shows a diagram of the SST analyte ranking process using the WC ranking method.

In Tables 3.5 and 3.6 , only $13 \%$ of the SST analytes were ranked Type I-A based on the WC ranking method, $16 \%$ of the analytes are Type I-B, $4 \%$ are Type II-A, and $7 \%$ are Type II-B. This leaves $36 \%$ of the analytes that were ranked as Type III and $24 \%$ unranked based on the WC ranking method.

The analytes that were ranked other than Type III by the WC method were ranked as such based primarily on the toxicity parameter (RfD, cancer potency factor, or radiological dosimetry factor) of the analytes. Analytes such as ${ }^{241} \mathrm{Am},{ }^{239} \mathrm{Pu},{ }^{240} \mathrm{Pu},{ }^{99} \mathrm{TC}, \mathrm{NO}_{2}, \mathrm{NO}_{j}, \mathrm{Cr}^{+6}, \mathrm{Fe}, \mathrm{OH}, \mathrm{Na}$, and $\mathrm{Bi}$ are Type I-A 


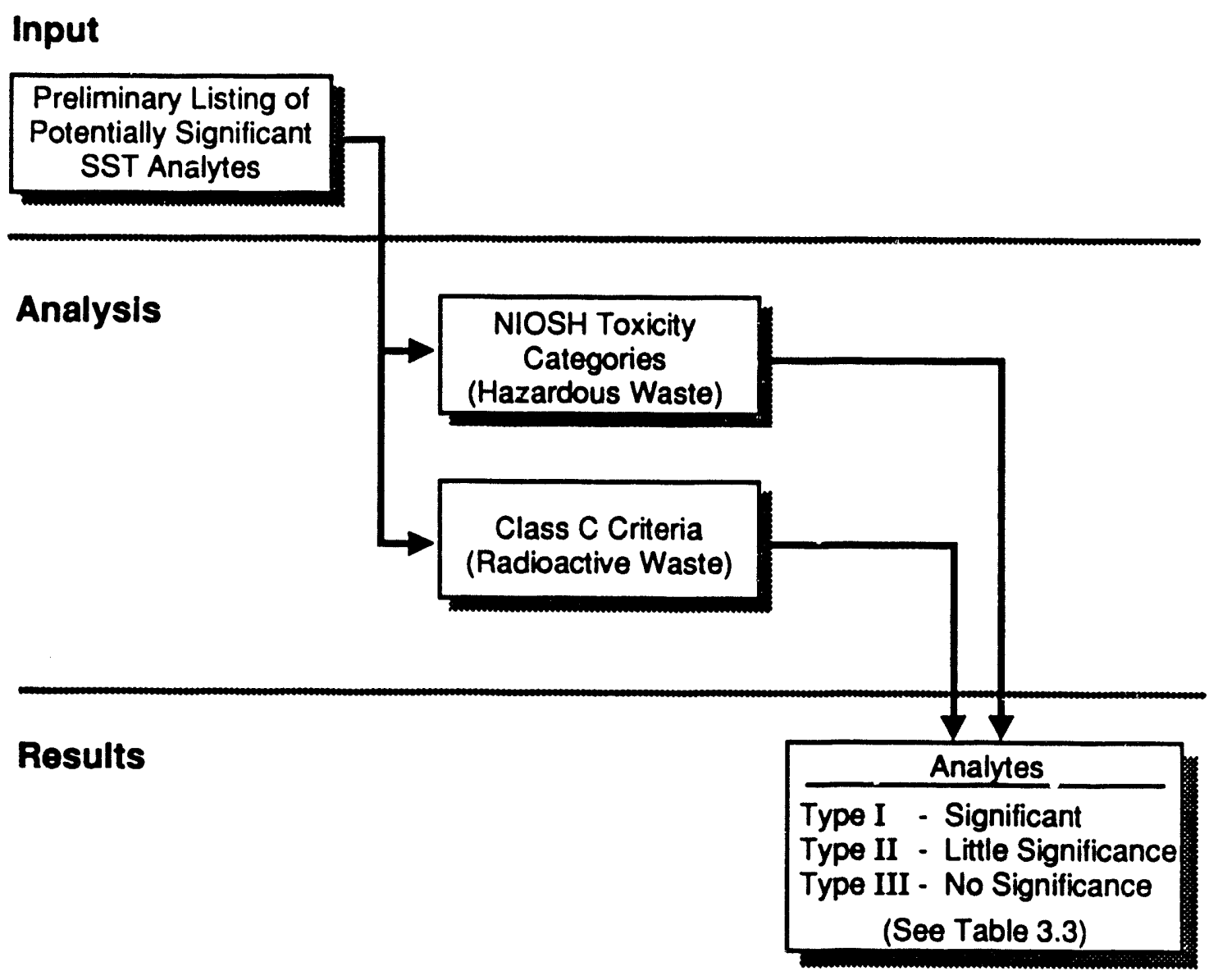

R9012111.4

FIGURE 3.3. The Single-Shell Tank Analyte Ranking Process Using the Waste Classification Ranking Method

analytes based on the WC method. The WC ranking method does not consider contaminant release rates or transport parameters as does the LTRR ranking method. 


\subsection{CONCENTRATION THRESHOLD VALUES FOR SINGLE-SHELL. TANK ANALYTES}

Another objective of this analysis in support of the SST Waste Characterization Plan is to estimate a concentration threshold (CT) value for each analyte. The CT values are expected to serve as an input in selecting suspect ADLs and to aid in evaluating remediation technologies.

The CT concept defines the concentration at which an analyte present in SSTs begins to make a significant contribution to a risk or waste class ranking. For this analysis, an analyte is declared to be a "significant contributor" if it provides at least $1 \%$ of the cumulative risk or waste class for a tank farm group. Conversely, an analyte is not considered a significant contributor if its contribution is less than $1 \%$ of the cumulative risk or waste class.

Concentration threshold values were estimated for each analyte based on results from the three ranking methods described in Chapter 3.0 and for each of the six tank farm groups. However, for certain analytes considered in the LTRR method, no CT value could be computed because of the nature of the solubility-controlled release (no matter how much the tank concentration was increased, the analyte could not contribute $1 \%$ of the total risk because the release rates are solubility-limited).

Finally, although $\mathrm{CT}$ values based upon a $1 \%$ contribution criterion provide a first approximation, an additional check on the adequacy of the CT values was performed. The estimated CT values for the LTRR method were compared to generally accepted standard reference levels. A detailed description of this comparison is provided in Appendix $D$.

The 24 SST analytes that were not rarked in Chapter 3.0 because of lack of tank inventories were evaluated using the CT concept if exposure data was available. These analytes could be evaluated because the $C_{i}$ concept is a hypothetical tank concentration based on a computed risk to the public; actual tank concentrations (inventories) are not required to compute the CT. Toxicity data were not available for $\mathrm{S}^{-2}$, Th, and $\mathrm{Ti}$, making the CT calcula $\mathrm{C}_{\text {ion }}$ impossible for these analytes. The other 21 unranked analytes did have CT values computed. 


\subsection{LONG-TERM RELEASE RISK CONCENTRATION THRESHOLD VALUES}

The CT values were computed for each analyte using the MEPAS groundwater and associated exposure pathway models. The SST concentration was adjusted iteratively and evaluated until the risk index for that analyte contributed $1 \%$ of the cumulative risk for that tank farm group. This $1 \%$ of the cumulative risk is referred to as the $\mathrm{Cr}$ for that analyte in that tank farm group.

There are four categories of analytes in this CT analysis for LTRR, analytes that 1) had to have their concentrations reduced below the TRAC estimate to reach the $C T, 2$ ) had to have their concentrations increased above the TRAC concentration to reach the $\mathrm{CT}, 3$ ) did not reach the $\mathrm{CT}$ by increasing the concentration because its solubility limit was low and the groundwater release was 1 imited, and 4 ) did not reach the CT because the analyte was not mobile enough to arrive at the receptor within the modeling time of 10,000years (combination of slow release rate and high $K_{d}$ associated with the transport velocity).

A few analytes had risk indexes greater than the $1 \%$ cumulative risk, and therefore their concentration needed to be reduced to reach the CT. Many of these analytes had very high inventories relative to the solubility release limit and thus the maximum predicted groundwater concentration at the well was insensitive to small changes in the inventory. Thus, the concentrations for these analytes had to be reduced by a large amount before their release rate decreased and the risk index began to decrease. Analytes of this type included $\mathrm{NO}_{2}, \mathrm{NO}_{3}$, EDTA, ${ }^{14} \mathrm{C},{ }^{129} \mathrm{I},{ }^{99} \mathrm{TC},{ }^{235} \mathrm{U}$, and ${ }^{238} \mathrm{U}$. These analytes had the highest risk indexes and were previously identified as Type I analytes (Table 3.1) based on the LTRR ranking method.

Analytes that had their concentrations increased to reach the $C T$ included $\mathrm{F}, \mathrm{CN}, \mathrm{Cl}$, and $\mathrm{Cr}^{+6}$. These analytes are generally Type I-A and I-B analytes.

Normally the risk index for an analyte would be proportional to its concentration if the release rate of the analyte remained constant, which is the case for this analysis. But if the anaiyte concentration in the groundwater is at its solubility limit, an increase or decrease in inventory will not change the risk. Analytes of this type were $\mathrm{Ag}, \mathrm{SO}_{4}, \mathrm{Ni}, \mathrm{Na},{ }^{93 \mathrm{~m}} \mathrm{Nb},{ }^{233} \mathrm{U}$, and ${ }^{234} \mathrm{U}$. These analytes are generally II-A and II-B analytes. 
Analytes such as $\mathrm{Al}, \mathrm{Ba}, \mathrm{Mn}, \mathrm{Zr}, \mathrm{Pb},{ }^{90} \mathrm{Sr},{ }^{137} \mathrm{Cs},{ }^{210} \mathrm{~Pb}$, and ${ }^{229} \mathrm{Th}$ did not reach the receptor within the 10,000-year time limit either because the ir estimated $K_{d} s$ are too high or, in the case of ${ }^{96} \mathrm{Sr}$ and ${ }^{137} \mathrm{Cs}$, the half-life is too short. Other analytes have lower $K_{d} s$ but did not reach the $1 \%$ of the cumulative risk because their peak water concentration that corresponded to the CT occurred too far in the future (much later than 10,000 years). A11 of these analytes are Type III analytes.

Concentration threshold values were computed for all the analytes that could reach the $1 \%$ cumulative risk level. Tables E.1 and E.2 in Appendix $E$ contain a summary of the CT values for the carcinogenic and noncarcinogenic analytes, respectively, in each of the six tank farm grrups.

\subsection{SHORT-TERM INTRUDER RISK CONCENTRATION THRESHOLD VALUES}

To establish a CT value based on the STIR method, $1 \%$ of the sum of the toxicity indexes was used. Individual analyte concentrations were calculated simply by reversing the method used to obtain their individual toxicity index. For example, CT values were determined by multiplying $1 \%$ of the total toxicity index by the chemical's RfD value to obtain a concentration $(\mu \mathrm{g} / \mathrm{g})$. Following the same guidelines, CT values were calculated for all analytes and for all the exposure routes considered.

Tables E.3 through E.7 in Appendix E are summaries of the CT values for the STIR analytes by tank farm group. Most of these CT values are higher (less restrictive) than the $C T$ values from the LTRR method.

\subsection{WASTE CLASSIFICATION CONCENTRATION THRESHOLD VALUES}

As with the LTRR and STIR methods, CT values for the WC method were calculated. Based on $1 \%$ of the total WC index for each tank farm group, CT values $(\mu \mathrm{g} / \mathrm{g})$ were back-calculated for the chemical analytes. Concentration threshold values were computed by taking the $1 \%$ of the total WC index and multiplying the appropriate factor based on the analyte's NIOSH toxicity value (Table B.2 in Appendix B).

Concentration threshold values for radionuclides were based on the WC values for short-lived and long-lived low-level radioactive waste. Based on 
specific activity per mass $(\mu \mathrm{C} / \mathrm{g})$ for radionuclides in NRC's 10 CFR 61 document (Table B.I in Appendix B), WC indexes were computed by taking the TRAC codes estimate of the specific activity $(\mu \mathrm{Ci} / \mathrm{g})$ data and dividing it by the 10 CFR 61 limit. Concentration threshold values were computed based on $1 \%$ of the cumulative WC index for each radionuclide and multiplying it by the appropriate 10 CFR 61 limit.

Summary tables were created to easily identify those analytes of greatest concern as well as their corresponding CTs. Tables E.8 and E.9 in Appendix E show the CT values for each tank farm group for chemical and radionuclide analytes respectively, based on the WC method. For chemicals, it is apparent that tine CT values for STIR and WC methods are very similar, because they are both based primarily on analyte toxicity (NIOSH toxicity values).

\subsection{APPLICATION OF THE CONCENTRATION THRESHOLD CONCEPT}

Because of the large number of SST analytes that must be characterized, it is not realistic in cost, schedule, and worker impacts to analyze all possible SST analytes with the same amount of detail. The CT concept was developed to provide a means of identifying SST analytes that are judged to be significant or insignificant contributors to potential public health impacts and therefore to closure decisions. A CT value was computed for each SST analyte using the LTRR, STIR, and WC ranking methods.

The CT concept was used to relate other parameters to potential health impacts from SST waste. One of these parameters is the ADL. If ADLs for analytes are not sensitive enough, there is a potential for an analyte at concentrations below the ADL to pose significant health impacts. Therefore, the CT concept was used to define health impact DLGs that can be used to set criteria for the $A D L$.

The uncertainty of the LTRR CT calculation, based on input data, models, scenario definitions, and risk factors, is qualitatively estimated, based on expert judgment, to be a minimum of one order-of-magnitude. It is also observed that there is often some variability in the ADL for a given analyte from sample to sample by a factor of 10 (one order-of-magnitude). 
With the use of the CT concept and these preliminary estimates of uncertainty in model and analytical methods, DLGs can be determined. For LTRR CT values, the DLGs are proposed to be two orders-of-magnitude less than the computed CT value. For example, if the computed CT value is $1.0 \times 10^{-4} \mu \mathrm{Ci} / \mathrm{g}$ for an analyte, the DLG is $1.0 \times 10^{-6} \mu \mathrm{Ci} / \mathrm{g}$. In the future, statistical methods should be used to rigorously calculate DLGs that provide a reasonable amount of confidence that the actual analyte concentration in a tank is less than the CT.

In determining proposed DLGs for CT values based on STIR and WC, a value of one order-of-magnitude less than the computed CT values was considered reasonable. Unlike the LTRR method, the STIR and WC methods are based on generic site information and are used as standards; therefore, they are assumed not to have any uncertainty associated with them. This leaves only the uncertainties associated with the method of determining ADLs. For STIR and WC CT values, corresponding DLGs are proposed to be set at one order-ofmagnitude less than the computed CT value. For example, if the computed CT value is $1.0 \times 10^{-4} \mu \mathrm{Ci} / \mathrm{g}$ for an analyte, the proposed $\mathrm{DLG}$ is $1.0 \times 10^{-5} \mu \mathrm{Ci} / \mathrm{g}$.

Using these definitions, goals for ADLs can be based on health risk. Tables F.1 through F.4 in Appendix F present the proposed health impact DLGs for the most restrictive CT values for different types of analyte by tank farm group and the associated ADLs. TRAC and measured results from 241-B-110 are included in the tables in Appendix $F$ to provide a comparison with the ADLs and DLGs. These DLGs are preliminary and are expected to change as more data on the waste and better statistical techniques can be developed to assist in defining improved goals. 


\subsection{RESULTS AND CONCLUSIONS}

The objective of this volume is to determine preliminary DQOS for the SST Characterization Program. The approach consists of deriving a preliminary ranking of SST analytes based on risk and closure-related guidelines (type of data needed) and detection limit goals (DLGs) for analytes based on the concentration threshold (CT) concept (quality of data required). The preliminary ranking of SST waste analytes and the DLGs will be used in design of the sampling and analysis plan used in Phase IC characterization. These recommended DQOS are only preliminary and are expected to change as new data from other tanks are analyzed. The entire characterization process is iterative and will continue to evolve as new sample data are obtained and analyzed.

Closure-related analyte priorities were established (using the LTRR, STIR, and WC methods) by categorizing analytes into three types: I, II, and III. Type I analytes are estimated to contribute most of the public health impacts because they provide at least $99 \%$ of the cumulative health risk for a tank farm group. Type II analytes are estimated to contribute no more than $0.99 \%$ of the cumulative health risks for a tank farm group. Types I and II analytes are estimated to contribute a combined total of at least $99.99 \%$ of the cumulative risk. By comparison, the Type III analytes are estimated to contribute no significant public health impacts, as they are estimated to contribute less than $0.01 \%$ of cumulative risk for a tank farm group.

Closure-related decisions for SST wastes are expected to be based heavily upon results from risk assessments. Therefore, the analyte ranking and CT evaluations included considerations of methods for LTRR and STIR. Carcinogens and noncarcinogens were considered separately because of their different health effects. As a check, analyte priorities and CT values were developed using WC criteria. The analyte priorities and CT values were calculated separately for six different tank farm groups, based upon geologic settings.

The CT value for each SST analyte is defined to be that concentration at which its contribution to a risk- or waste-class-calculation is judged to become significant. For the purposes of this report, significant is defined as constituting $1 \%$ of the cumulative risk or waste class index (based on LTRR, 
STIR, and WC) for each tank farm group. The computed CT values were then used to define DLGs based on health risk and waste class. Analyte priorities, DLGs, and other tank data can be used to identify current analytical methods that may need improvement.

Type I analytes are expected to play the greatest role in closure decisions. However, because there are a number of uncertainties associated with the tank inventories and transport parameters for the LTRR calculations, nearterm (Limited Phase IC Characterization over the next 1-2 years) characterization efforts should continue to include Type II and III analytes. Recommendations in this report are designated by the volume they come from and numerical order in that volume (i.e., Recommendation 2-3 is the third recommendation from Volume 2). There are four key recommendations within this volume:

- Recommendation 2-1: For the Limited Phase IC Characterization program, a sampling and analysis objective related to closure decisions should be to generate inventory estimates for the Type I and II analytes. These analytes should additionally receive the greatest attention in terms of accuracy requirements.

- Recommendation 2-2: The Limited Phase IC Characterization program should include tests which provide for reducing the uncertainties associated with closure-related analyte priorities. This includes empirical solubility limits (i.e., source-term data) and adsorption coefficients (i.e., $K_{d}$ values) in support of Long-Term Release Risk assessments (i.e., performance assessments). This information should be generated over a diverse set of waste types.

- Recommendation 2-3: To the extent feasible, analyses conducted under the Limited Phase IC Characterization program should be designed such that analytical detection limits are one order-ofmagnitude below computed STIR and WC CT and two orders-of-magnitude below computed LTRR CT values.

- Recommendation 2-4: The Extended Phase IC Characterization program should be designed so that when detection limits are not exceeded there is sufficient confidence that the true concentration does not exceed the computed CT value. 


\subsection{SELECTION OF ANALYTE PRIORITTES}

Phase IC Characterization data will be used for determining which analytes make the greatest contribution to public health impacts and confirming that other analytes are insignificant to public health impacts. The combined rankings of SST analytes based on all three ranking scenarios are provided in Table 5.1 (identified as Priority Case 1) and a schematic of this process is shown in Figure 5.1. An analyte is assigned to a particular type based upon its highest rank in the three scenarios. Thus, if an analyte scores Type I-A, Type II-A, and Type II-A, the combined ranking is the most conservative, I-A. If the scores are Type II-B, II-A, II-B, the score is II-A. Analytes that are not Type I-A, I-B, II-A, or II-B for any of the ranking scenarios are categorized as Type III analytes.

Of the 100 analytes studied, 50 were Type I or Type II analytes. Table 5.1 indicates that together these analytes contribute at least $99.99 \%$ of the cumulative risk for a tank farm group. Thirty-eight of the 100 SST analytes were Type I, 11 were Type II, 27 were Type III, and 24 were unranked (lack of tank inventory). The analyte selection criteria are identified at the bottom of Table 5.1. As additional information is gathered through the characterization of the tank wastes, it will be possible to reduce conservatism in this analysis; a likely outcome will be the "de-ranking" of some analytes.

To illustrate the use of the analyte priorities, an alternate set of priorities was developed for comparison purposes (identified as Priority Case 2 in Table 5.2). Priority Case 2 gives more emphasis to the LTRR ranking scenario by shifting all the STIR and WC ranking analytes down one category; for example, from Type I-A to I-B. Otherwise, the process for determining the combined ranking score was the same as in Priority Case 1 . This report recommends Priority Case 1 as the list of analyte priorities to be used in Phase IC characterization efforts.

\subsection{DETERMINATION OF CONCENTRATION THRESHOLD VALUES}

The most restrictive $C T$ values computed for all three ranking methods are provided in Tables 5.3 and 5.4 for carcinogen and noncarcinogen analytes, 
TABLE 5.1. Combined SST Analyte Ranking (Priority Case 1) (a) $^{(a)}$ Carcinogen

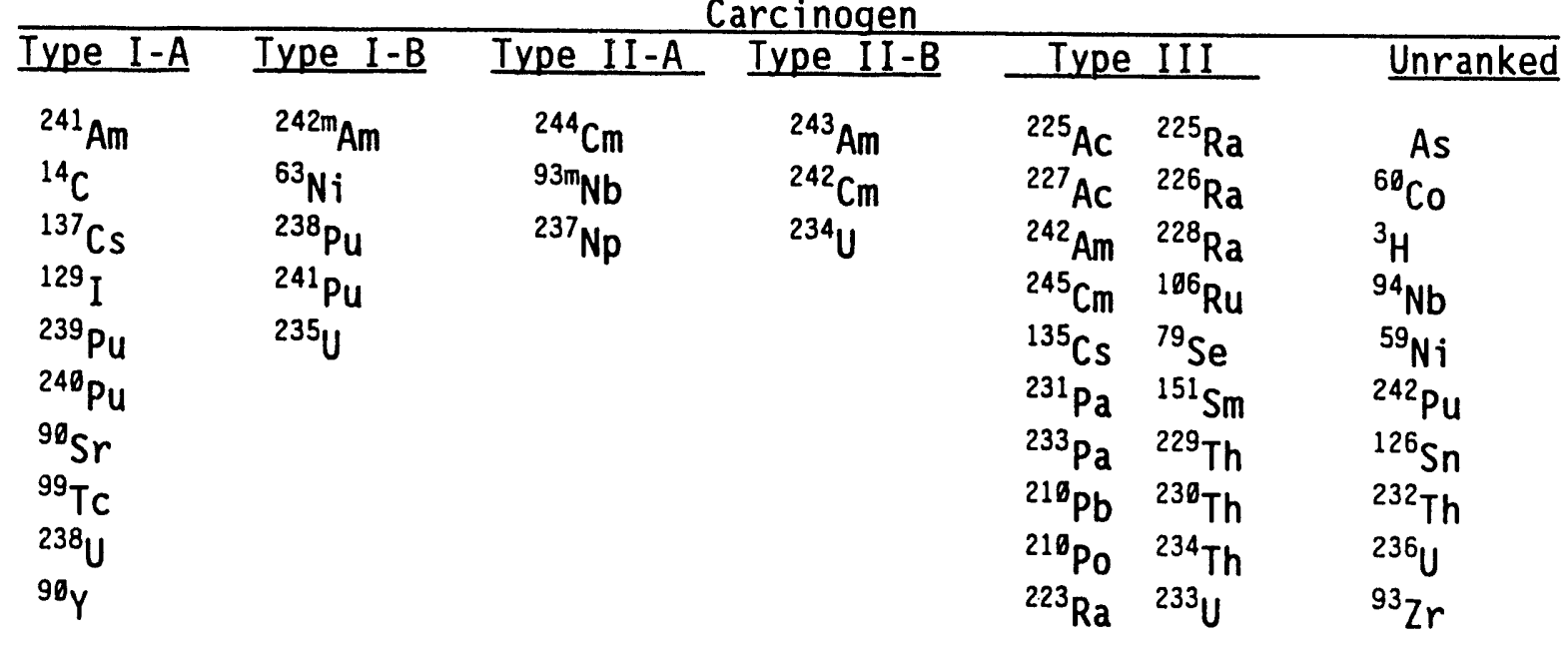

Noncarcinogen

Iype I-A Iype I-B Type II-A Iype II-B Type III Unranked

$\begin{array}{llllll}\mathrm{Al} & \mathrm{Ba} & \mathrm{Ag} & \mathrm{C}_{2} \mathrm{H}_{3} \mathrm{O}_{3} & \mathrm{C}_{2} \mathrm{O}_{4} & \mathrm{Be} \\ \mathrm{Bi} & \mathrm{C}_{6} \mathrm{H}_{5} \mathrm{O}_{7} & \mathrm{Fe}(\mathrm{CN})_{6} & \mathrm{Ca} & \mathrm{Ce} & \mathrm{Co} \\ \mathrm{Cr}+6 & \mathrm{Cd} & & \mathrm{K} & \mathrm{Cl} & \mathrm{Cu} \\ \mathrm{EDTA} & \mathrm{CN} & & & \mathrm{La} & \mathrm{Hg} \\ \mathrm{F} & \mathrm{CO}_{3} & & & \mathrm{SeO}_{4} & \mathrm{NH}_{3} \\ \mathrm{Fe} & \mathrm{HEDTA} & & & \mathrm{Sn} & \mathrm{Sb} \\ \mathrm{Mn} & \mathrm{Pb} & & & \mathrm{WO}_{4} & \mathrm{Sr} \\ \mathrm{Na} & \mathrm{SiO}_{3} & & & \mathrm{~S} \\ \mathrm{Ni} & \mathrm{SO}_{4} & & & \mathrm{Th} \\ \mathrm{NO}_{2} & \mathrm{Zr} & & & \mathrm{Tl} \\ \mathrm{NO}_{3} & & & & \mathrm{Ti} \\ \mathrm{OH}^{+2} & & & & \mathrm{U} \\ \mathrm{PO}_{4} & & & & \mathrm{~V} \\ & & & & \mathrm{Zn}\end{array}$

(a) Type I-A analytes include 0.00 to $90.00 \%$ of cumulative ranking index. Type I-B analytes include 90.00 to $99.00 \%$ of cumulative ranking index. Type II-A analytes include 99.00 to $99.90 \%$ of cumulative ranking index. Type II - B analytes include 99.90 to $99.99 \%$ of cumulative ranking index. Type III analytes $<99.99 \%$ of cumulative ranking index. 


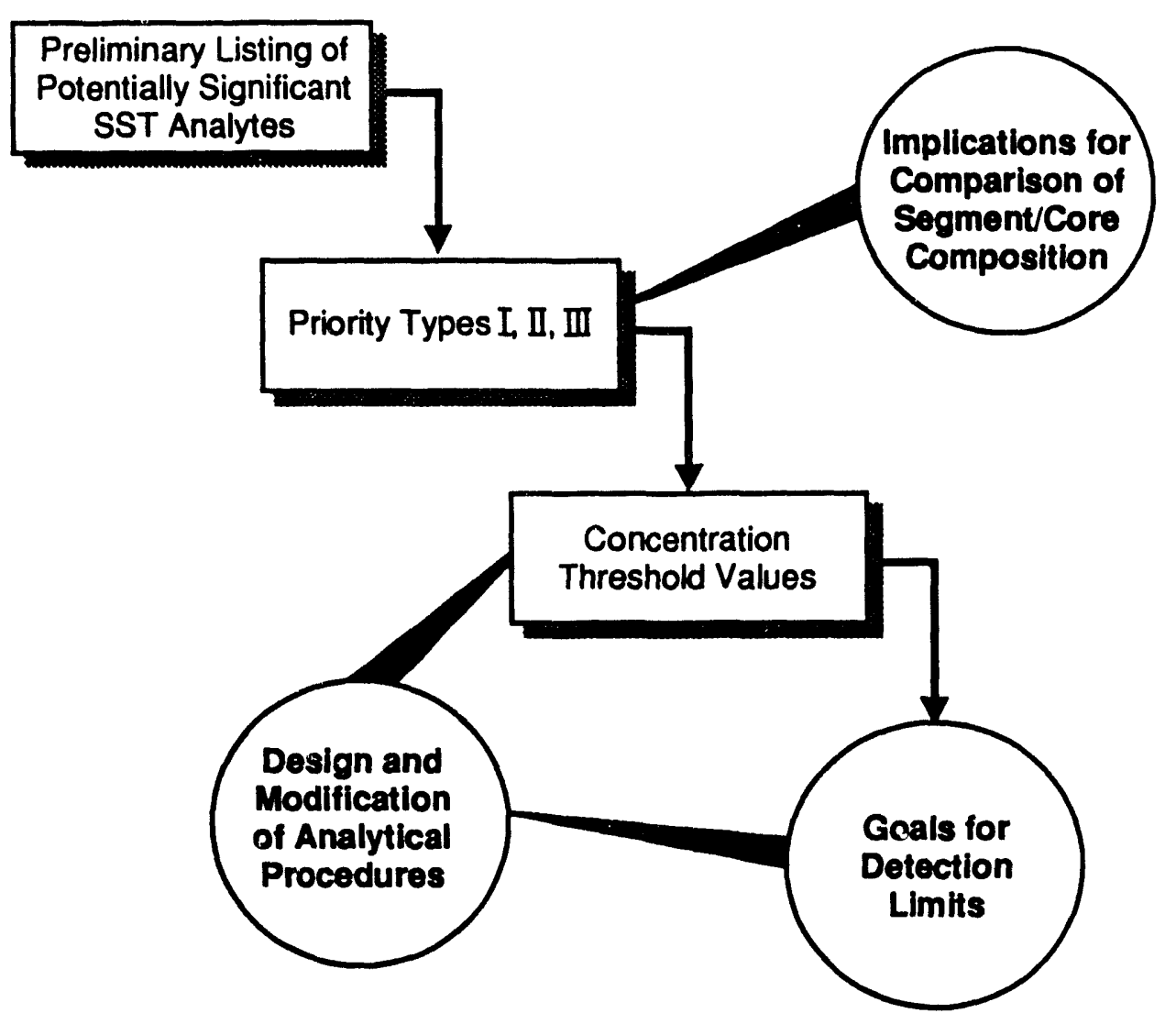

R9012111.10a

FIGURE 5.1. Diagram of the Single-Shell Tank Analyte Ranking Process Using All Three Ranking Methods

respectively and a diagram of the process in shown in Figure 5.2. In general, the LTRR CT values are the most restrictive except for certain transuranics $\left({ }^{241} \mathrm{Am},{ }^{244} \mathrm{Cm},{ }^{238} \mathrm{Pu},{ }^{239} \mathrm{Pu},{ }^{240} \mathrm{Pu}\right.$, and ${ }^{241} \mathrm{Pu}$ radionuclides $)$; these radionuclides' risk indexes result from decay products rather than the parent constituent itself.

It is unclear why the risk indexes for transuranics are different from the other ranking-based CTs; it may be that the institutional limit for transuranics, set at $100 \mathrm{nCi} / \mathrm{g}$, is more restrictive (on a public health basis) than for other radionuclides. Alternately, it may be that the congruent release method used in the multimedia environmental pollutant system (MEPAS) for 
TABLE 5.2. Alternate Combined SST Analyte Ranking (Priority Case 2)(a)

\begin{tabular}{|c|c|c|c|c|c|c|}
\hline \multicolumn{7}{|c|}{ cinogen } \\
\hline${ }^{14} \mathrm{C}$ & ${ }^{241} \mathrm{Am}$ & ${ }^{93} \mathrm{~m}_{\mathrm{Nh}}$ & ${ }^{242} \mathrm{~cm}$ & & & \\
\hline${ }^{129} \mathrm{I}$ & $242 \mathrm{~m}_{\mathrm{Am}}$ & ${ }^{63} \mathrm{Ni}$ & ${ }^{244} \mathrm{~cm}$ & ${ }^{227} \mathrm{AC}$ & $225 \mathrm{R}_{2}$ & $\begin{array}{l}\text { AS } \\
6 \theta_{r}\end{array}$ \\
\hline${ }^{99} \mathrm{Tc}$ & ${ }^{137} \mathrm{Cs}$ & ${ }^{238} \mathrm{Pu}$ & ${ }^{237} \mathrm{~Np}$ & ${ }^{242} \mathrm{Am}$ & ${ }^{226} \mathrm{Ra}$ & ${ }_{3} \mathrm{H}$ \\
\hline${ }^{238} \mathrm{U}$ & ${ }^{239} \mathrm{Pu}$ & ${ }^{241} \mathrm{Pu}$ & ${ }^{234} \mathrm{U}$ & ${ }^{243} \mathrm{Am}$ & ${ }^{228} \mathrm{Ra}$ & ${ }^{94} \mathrm{Nb}$ \\
\hline & ${ }^{246} \mathrm{Pu}$ & & & ${ }^{245} \mathrm{Cm}$ & ${ }^{106} \mathrm{Ru}$ & ${ }^{59} \mathrm{Ni}$ \\
\hline & ${ }^{98} \mathrm{Sr}$ & & & ${ }^{135} \mathrm{Cs}$ & ${ }^{79} \mathrm{Se}$ & ${ }^{242} \mathrm{Pu}$ \\
\hline & ${ }^{235} U$ & & & ${ }^{231} \mathrm{~Pa}$ & ${ }^{151} \mathrm{Sm}$ & ${ }^{126} \mathrm{Sn}$ \\
\hline & ${ }^{90} Y$ & & & ${ }^{233} \mathrm{~Pa}$ & ${ }^{229} \mathrm{Th}$ & ${ }^{232} \mathrm{Th}$ \\
\hline & & & & ${ }^{218} \mathrm{~Pb}$ & ${ }^{238} \mathrm{Th}$ & ${ }^{236} \mathrm{U}$ \\
\hline & & & & ${ }^{21 \theta} \mathrm{Po}_{0}$ & $\begin{array}{l}{ }^{234} \mathrm{Th} \\
{ }^{233} \mathrm{i}\end{array}$ & ${ }^{93} \mathrm{Zr}$ \\
\hline
\end{tabular}

Noncarcinogen

Iype I-A Type I-B Iype II-A Type II-B Type III Unranked

$\begin{array}{lll}\text { EDTA } & \mathrm{Al} & \mathrm{Ba} \\ \mathrm{F} & \mathrm{Bi} & \mathrm{C}_{6} \mathrm{H}_{5} \mathrm{O}_{7} \\ \mathrm{NO}_{2} & \mathrm{CN} & \mathrm{Cd} \\ \mathrm{NO}_{3} & \mathrm{Cr}+6 & \mathrm{CO} \\ & \mathrm{Fe} & \mathrm{HEDTT} \\ & \mathrm{Mn} & \mathrm{Pb} \\ & \mathrm{Na} & \mathrm{SO}^{+6} \\ & \mathrm{Ni} & \mathrm{Si}_{3} \\ & \mathrm{OH} & \mathrm{Zr} \\ & \mathrm{PO}_{4} & \end{array}$

$\begin{array}{ll}\mathrm{Ag} & \mathrm{C}_{2} \mathrm{H}_{3} \mathrm{O}_{3} \\ \mathrm{Fe}(\mathrm{CN})_{6} & \mathrm{C}_{2} \mathrm{O}_{4} \\ & \mathrm{Ca}^{2} \\ & \mathrm{Ce} \\ & \mathrm{Cl} \\ & \mathrm{K} \\ & \mathrm{La} \\ & \mathrm{SeO}_{4} \\ & \mathrm{Sn} \\ & \mathrm{WO}_{4}\end{array}$

$\mathrm{Be}$
$\mathrm{Co}$
$\mathrm{Cu}$
$\mathrm{Hg}$
$\mathrm{NH}^{3}$
$\mathrm{Sb}^{3}$
$\mathrm{Sr}$
$\mathrm{S}^{-2}$
$\mathrm{Th}$
$\mathrm{T}$
$\mathrm{Ti}$
$\mathrm{U}$
$\mathrm{V}$
$\mathrm{Zn}$

(a) Type I-A Analytes, 0 to $90 \%$ from LTRR rankings only. Type I-B Analytes, 90 to $99 \%$ from LTRR and 0 to $90 \%$ from STIR and WC rankings.

Type II-A Analytes, 99 to $99.9 \%$ from LTRR and 90 to $99 \%$ from STIR and WC. Type II-B Analytes, 99.9 to $99.99 \%$ from LTRR and 99 to $99.9 \%$ from STIR and $W C$.

Type III Analytes, $<99.99 \%$ from LTRR and $<=99.9 \%$ from STIR and WC rankings. 
TABLE 5.3. Concentration Threshold Values for Carcinogen
Analytes (Most Limiting Tank Farm)

\begin{tabular}{|c|}
\hline $\begin{array}{l}\text { Carcinogen } \\
\text { Const ituent } \\
225 \mathrm{Ac} \\
227_{\mathrm{Ac}} \\
241_{\mathrm{Am}} \\
242_{\mathrm{Am}} \\
242 \mathrm{~m} \\
243_{\mathrm{Am}} \\
{ }_{\mathrm{Am}} \\
242_{\mathrm{enic}}(\mathrm{b}) \\
244_{\mathrm{Cm}} \\
245 \mathrm{Cm} \\
135 \mathrm{Cs} \\
137_{\mathrm{Cs}} \\
14 \mathrm{C} \\
60 \mathrm{Co} \\
3_{\mathrm{H}} \\
129\end{array}$ \\
\hline
\end{tabular}

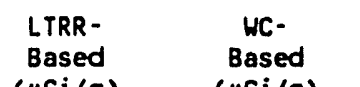

$(\mu \mathrm{Ci} / \mathrm{g})$

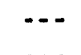

$8 \mathrm{E}+01$

4. $1 \mathrm{E}-04$

.TE-01

2.2E-02

6. $1 E+01$

..-

$\cdots$

6.3E-04

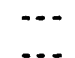

...

2. 1E-06

$\cdots$

$\cdots$

-..-

...

3.7E-03

-..

...

-..

8.4E-02

$1.1 E+00$

1.6E-01

$5.9 E+02$

...

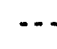

-..

-..

$\cdots$

$\ldots$

....

$\cdots$

....

1. $4 E-04$

...

...

...

...

$\ldots$

4. $4 E-06$

$2.6 E-06$

$6.8 E-06$

..-
Based
( $\mu \mathrm{Ci} / \mathrm{g})$

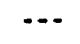

-..

3. $0 E-04$

...

3. $0 E-04$

3. $0 E-04$

$9 E-02$

3. OE-04

3. 0E-04

-

3.8E-01

5.8E-02

3.3E-03

1. $3 E-04$

3.3E-04

3.6E-01

5.8E-02

3. $0 E-04$

-..

…

$\cdots$

3. OE-04

3. $0 E-04$

3. $0 \mathrm{E}-04$

1. OE-02

...

...

...

-..$$
\cdots
$$$$
\text { -.. }
$$$$
\text { -.. }
$$

5.8E-01

4. $9 E-03$

...

-..

...

-..

-..

...

$\cdots$

$\cdots$

-..

$\cdots$

$\cdots$

Inhalation Ingestion

(ucision

( $\mathrm{M}$ (i/g)

4. 1E-02

8. $6 E-04$

$7.5 E+00$

8.8E-04

8.6E-04

…

$1.6 E-03$

8.2E-04

...

4. $9 E+01$

2.1E+02

2. $0 E+00$

$7.1 E+03$

2. $6 E+00$

$1 \mathrm{C}+\mathrm{C}^{-.}$

$1.7 E+02$

7.1E+01

9. $0 E-04$

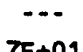

4. $7 E+01$

8E-02

9. $8 \mathrm{E}-04$

8.6E-04

8.6E-04

4.5E-02

$1.1 E-03$

5.8E-02

5.8E-02

-..

1. $0 E+00$

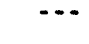

2. $3 E+01$

3.5E-01

5. $4 E+01$

$1.4 E-03$

2.8E-04

$1.3 E+01$

3.5E-03

3. $5 E-03$

3. $7 \mathrm{E}-03$

3.5E-03

3.7E-03

5.3E+01

1. $4 E+00$
( $\mu \mathrm{Ci} / \mathrm{g})$

3. 0E-01

- $\cdots$

2. $5 E+01$

1. $6 E-02$

7.3E-03

4. $7 \mathrm{E}-01$

2.7E-02

1.4E-02

...

2.7E+01

$1.6 \mathrm{E}+01$

$1.2 \mathrm{E}+00$

$5.2 E+02$

1.2E-01

$\cdots$
$\cdots E+00$

$4.6 E+00$
$1.6 E+02$

5. $6 E+01$

8.2E-04

-..

9. $1 E+00$

...

1.7E-02

8.6E-03

7.6E-03

7.6E-03

3. $8 \mathrm{E}-01$

9.7E-03

5. OE-02

8.6E-02

...

$1.2 E+00$

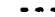

1. $3 E+00$

1. $3 E+00$

2. $2 E+01$

5.9E-02

1.2E- 02

$2.3 E+00$

1. $1 E-01$

1.2E-01

1.2E-01

1.2E-01

1.3E-01

$3.0 E+00$

$1.9 E+01$
Ground Exposure

$(\mu \mathrm{Ci} / \mathrm{g})$

$3.6 E+00$

$9 E+00$

2. $5 E+00$

2. $0 E+01$

9.0E-01

- $\bar{E}+01$

$6.8 E+01$

6.9E-01

4.0E-01

-..-

$2.6 E-02$

...

3.7E-02

$1.4 \mathrm{E}+02$

-..

1. $8 E+00$

-..

2.5E-0

$6.8 E+03$

$6.2 \mathrm{E}+01$

1. $5 \mathrm{E}+02$

$6.8 E+01$

$1.8 E+03$

$8.8 E+01$

3. $8 \mathrm{E}-01$

$3.8 E+00$

-..

$.6 E-01$

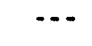

9.6E-01

$1.0 E+01$

$9.5 E+04$

-..

$6.2 E+01$

$8.4 E+01$

$5.7 E+00$

1. $1 E+02$

6. $9 E+01$

3. $4 E-01$

$7.5 E+01$

8.5E+01

5.7E-01

...
Proposed Goal for Detection Limit $(\mu \mathrm{C} i / g)$

4.1E-03

3. $0 \mathrm{E}-05$

2.5E-01

3. $0 \mathrm{E}-05$

3.0E-05

1.7E-03

2.2E- 04

3.0E-05

3. OE-05

3. $8 \mathrm{E}-02$

6.3E-06

2.6E-03

3.3E-04

2.1E-08 NMA $(C)$

3.3E-05

3.6E-02

$5.8 \mathrm{E}-03$

3. OE-05

$2.5 E-02$

1.7E-03

$3.0 E-05$

3. $0 E-05$

3. OE-OS

1. $0 E-03$

1.1E-04

5. OE-03

5. $8 \mathrm{E}-03$

-..

1.6E-02

-..

9.6E-02

2.3E-02

$1.4 E-06$

$1.4 E-04$

2.8E-05

2.3E- 01

$3.5 E-04$

$3.5 E-04$

$4.4 E-08$

$2.6 E-08$

$6.8 E-08$

$5.7 \mathrm{E}-02$

$1.4 E-01$

(a) -.. Indicates that was not computed or available.

(b) Concentrations in $\mathrm{g} / \mathrm{g}$ for As (arsenic).

(c) NMA $=$ No method available. 
TABLE 5.4. Concentration Threshold Values for Noncarcinogen Analytes (Most Limiting Tank Farm) ${ }^{(a)}$

\begin{tabular}{|c|c|c|}
\hline $\begin{array}{c}\text { Non- } \\
\text { carcinogen } \\
\text { Constituent }\end{array}$ & $\begin{array}{l}\text { LTRR- } \\
\text { Based } \\
\text { ( } \mu g / g)\end{array}$ & $\begin{array}{c}\text { WC- } \\
\text { Based } \\
\text { (ug/g) }\end{array}$ \\
\hline Ag & $\cdots$ & $4.4 E+02$ \\
\hline Al & $\cdots$ & $4.4 E+03$ \\
\hline $\mathrm{Ba}$ & $\ldots$ & $4.4 E+02$ \\
\hline Be & 3.3E-01 & $\ldots$ \\
\hline$B \mathbf{i}$ & $\ldots$ & $4.4 E+01$ \\
\hline $\mathrm{C}_{2} \mathrm{H}_{3} \mathrm{O}_{3}$ & $\cdots$ & $4.4 E+03$ \\
\hline $\mathrm{C}_{2} \mathrm{O}_{4}$ & $\cdots$ & $4.4 E+02$ \\
\hline $\mathrm{C}_{6} \mathrm{H}_{5}^{4} \mathrm{O}_{7}$ & $\cdots$ & $4.4 E+03$ \\
\hline $\mathbf{c a}^{2}$ & $\ldots$ & $6.4 E+03$ \\
\hline $\mathrm{Ce}$ & $\ldots$ & $4.4 E+03$ \\
\hline Cd & $\ldots$ & $4.4 E+02$ \\
\hline $\mathrm{Cl}$ & 1. $1 E+02$ & $4.4 E+03$ \\
\hline CN & $3.8 E-01$ & $\ldots$ \\
\hline Co & -. & $4.4 E+02$ \\
\hline $\mathrm{CO}_{3}$ & $\cdots$ & $4.4 E+03$ \\
\hline $\mathrm{Cr}^{76}$ & $4.1 E+02$ & $4.4 E+02$ \\
\hline $\mathrm{Cu}(b)$ & $\ldots$ & $\ldots$ \\
\hline EDTA & $8.8 E-02$ & $4.4 E+03$ \\
\hline $\mathbf{F}$ & $1.1 E+02$ & $4.4 E+03$ \\
\hline $\mathrm{Fe}$ & $\ldots$ & $4.4 E+02$ \\
\hline $\mathrm{Fe}(\mathrm{CN})_{6}$ & $\cdots$ & $4.4 E+03$ \\
\hline HEDTA & $\ldots$ & $4.4 E+02$ \\
\hline $\mathrm{Hg}$ & $7.8 E-01$ & $4.4 E+01$ \\
\hline K & $\ldots$ & $4.4 E+03$ \\
\hline La & $\ldots$ & $4.4 E+03$ \\
\hline Mn & $\ldots$ & $4.4 E+03$ \\
\hline $\mathrm{Na}$ & $\ldots$ & $4.4 E+03$ \\
\hline $\mathrm{NH}_{3}$ & $\ldots$ & $4.4 E+01$ \\
\hline $\mathrm{Ni}^{3}$ & $\ldots$ & $4.4 E+02$ \\
\hline $\mathrm{NO}_{2}$ & $4.3 E+00$ & $4.4 E+03$ \\
\hline $\mathrm{NO}_{3}^{\mathrm{L}}$ & $9.4 E+01$ & 4. $4 E+03$ \\
\hline $\mathrm{OH}^{2}$ & $\ldots$ & $4.4 E+02$ \\
\hline $\mathrm{Pb}$ & $\ldots$ & $4.4 E+03$ \\
\hline $\mathrm{PO}_{4}$ & $\cdots$ & $4.4 E+03$ \\
\hline$s^{-2}$ & $\ldots$ & $\cdots$ \\
\hline Sb & 9.0 E-01 & $\ldots$ \\
\hline $\mathrm{SeO}_{4}$ & $\ldots$ & $4.4 E+00$ \\
\hline $\mathrm{SiO}_{3}^{4}$ & $\cdots$ & $4.4 E+03$ \\
\hline $\mathrm{Sn}^{2}$ & $\cdots$ & $4.4 E+03$ \\
\hline $\mathrm{SO}_{4}$ & $\ldots$ & $4.4 E+03$ \\
\hline $\mathrm{Sr}^{4}$ & $\ldots$ & $4.4 E+03$ \\
\hline$T h^{(b)}$ & $\cdots$ & $\ldots$ \\
\hline$T i^{(b)}$ & $\ldots$ & $\ldots$ \\
\hline Tl & $\ldots$ & 4. $4 E+00$ \\
\hline$v$ & $4.9 E+01$ & $\ldots$ \\
\hline $\mathrm{NO}_{4}$ & $\ldots$ & $4.4 E+03$ \\
\hline$u^{4}$ & $\ldots$ & $4.4 E+02$ \\
\hline $2 n$ & $\ldots$ & $4.4 E+02$ \\
\hline $2 r$ & $\ldots$ & $4.4 E+03$ \\
\hline
\end{tabular}

\begin{tabular}{cc}
\multicolumn{2}{c}{ STIR } \\
$\begin{array}{c}\text { Inhalation } \\
(\mu g / g)\end{array}$ & $\begin{array}{c}\text { Ingestion } \\
(\mu g / g)\end{array}$ \\
&
\end{tabular}

Proposed Goal for Detection Limit

$1.9 E+01$

8.7E+01 6.3E+01 $6.3 E+00$

$8.7 E+00 \quad 2.3 E+03 \quad 8.7 E-01$

$3.3 E-03$

$3.9 E+00$

$5.5 E+01 \quad 3.9 E+01$

$4.4 E+02$

4.5E+02 $\quad 3.2 E+02$

$2.5 E+03$

$5.2 E+03$

$1.8 E+03$

$5.3 E+00$

$2.2 E+02$

$3.8 E+03$

$2.3 E+01$

$1.6 E+02$

$3.6 E+02$

4. $.6 E+03$

2.2E+01

7.9E-01

$3.3 E+03$

$2.2 E+02$

$3.2 E+01$

$4.4 E+02$

$1.8 E+02$

$3.8 E+02$

5.3E-01

$1.1 E+00$

$3.8 \mathrm{E}-03$

2. $2 \mathrm{E}+00$

$3.3 E+02$

$7.9 E-02$

8. $0 E+01$

$5.8 E+01$

3.7E+03 2. $T E+03$

$5.3 E+02$

$2.7 E+03$
$5.8 E+04$

$1.2 E+03$

$8.9 E+02$

$8.3 E+02$

$3.2 E+00$

$3.2 E+07$

$1.0 E+04$

$1.9 E+01$

$1.9 E+07$

$5.8 E+03$

$3.9 E+01$

2. $1 E+02$

$6.2 E+04$

9. $0 E+02$

2.7E+01

4. $3 E+02$

$6.0 E+02$

$8.9 E+01$

2.3E+07

$7.5 E+03$

9. $8 \mathrm{E}+03$

$1.3 E+07$

8. $1 E+03$

$8.9 E+02$

$1.5 E+02$

$4.5 E+04$

$6.5 E+02$

6.3E+01

2. $1 E+04$

8. $8 E-04$

$1.1 E+00$

4. $4 E+01$

$8.9 E+01$

$4.4 E+01$

7.8E-03

$4.4 E+02$

$4.4 E+02$

$1.9 E+00$

$4.8 E+02$

$4.4 E+00$

$3.9 E+00$

4.3E-02

9.4E-01

4. $4 E+01$

2. $7 E+00$

4. $3 E+01$

-..

4. $0 E+00$

$1.2 E+04$

8.7E+02

$4.3 E+03$

8.5E+03

-..

$2.9 E+00$

$1.3 E+02$

$4.5 E+02$

$3.2 E+06$

$1.1 E+04$

...

1. $8 E+01$

$\cdots$

$1.0 E+02$

9.0E-03

2. $9 E-01$

1. $3 E+01$

4. $5 E+01$

4. $3 E+02$

$4.4 E+02$

-..

4. $4 E-01$

4. $9 E-01$

$7.4 E+03$

-..

2. $1 E+02$

6.3E+01

2. $1 E+03$

$4.9 E+04$

8. $\mathrm{TE}+01$

$6.3 E+00$

4. $4 E+01$

4. $1 E+02$

(a) -... Indicates that was not computed or available.

(b) No toxicity data available. 


\section{Input}

\section{Preliminary Listing of Potentially Significant SST Analytes}

Analysis

Long-Term Release

Risk Method

\section{Short-Term Intruder}

Risk Method

\section{Results}

\section{Waste Classificaticin} Method

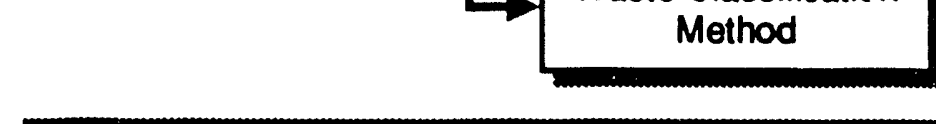

R9012111.5

EIGURE 5.2. Diagram of the Single-Shell Tank Analyte Correntration Threshold Values Using the Most Restrictive Values

radionuclides is not representative. Empirical tests on solubility limits and adsorption coefficients will assist in resolving this issue.

In the case of the noncarcinogen analytes (Table 5.4), the LTRR CT is always the most restrictive when a value can be computed (only $28 \%$ of the 
analytes have a CT for the LTRR case because they are solubility-limited or because they do not reach the receptor within the 10,000-year time limit of the modeling time). The WC and STIR CT values for noncarcinogens are very similar because they are both based mainly on the toxicity of the constituent. The LTRR CT values tend to be different because they depend on release, transport, and toxicity parameters.

\subsection{DETECTION LIMIT GOAL S BASED ON HEALTH RISK}

For Phase IC Characterization efforts, those analytes that provide a significant contribution to a closure decision for SSTs based on public health impacts are identified. The other analytes (Type III) should be confirmed not to be present in significant concentrations. The unranked analytes need to be addressed in this work to confirm that they are not significant contributors to risk.

The most restrictive CT value estimated for each analyte provides a measure of significant contribution based on public health risk. Using these CT values, DLGs can be defined to provide DQOs for analytical efforts. For this volume, two orders-of-magnitude below computed CT based on the LTRR method and one order-of-magnitude below computed CT based on STIR and WC methods were used. These DLGs provide sufficient confidence that if an analyte's mean tank concentration is found to be at or below the detection limit vaiue (based on health risk), it will not cause significant risk to the pubiic should the analyte get released.

Waste characterization efforts should have as a goi improving detection limits in which there can be confidence that the true analyte mean concentration in the tank can be quantified at levels below the corresponding CT value. To achieve this, the CT calculations need to be improved (more accuracy and greater confidence) by incorporating empirical solubility and adsorption values from laboratory tests on reference tank and new tank core samples. Modifications to analytical techniques and procedures to lower the detection 
limits or development of a new analytical technique that lowers detection limits would also improve confidence that detection limits are below CT values.

Again, it should be stated that the current computed CT values and DLGS are but a first estimate and should be used with caution. There is a great deal of uncertainty in the TRAC inventories and many assumptions had to be made to complete the risk calculations. Goals for the Limited Phase IC Characterization effort should include the collection of data which will support less conservative analyte priorities and LTRR CT values. Subsequent reassessments may also result in modified requirements for ADLs. In short, as more information is obtained on the characteristics of the waste and the nature of release/transport of analytes in the SSTs, better estimates of the analyte priorities, LTRR CT values, and DLGs can be made. Figure 5.3 shows a diagram of the relationship between the SST analyte ranking, CT values, and proposed DLGs using all three methods.

It is important to have DQOs that guide the sampling and analysis programs. The preliminary DLGs developed in this report will be used by the Waste Characterization Project as an initial check of ADLs. If an analyte's $A D L$ is greater than the computed DLG, that ADL is identified as suspect and will require further evaluation. The process of evaluating and modifying an analyte's ADL can be time-consuming and expensive. To expedite this process, the list of SST analytes with suspect ADLs needs to be prioritized.

One way of prioritizing work on suspect ADLs is determining whether the analyte is expected to be in the tank at quantities greater than the current $A D L$ value. A preliminary determination can be made using TRAC and measured 241-B-110 concentration data. Analytes with estimated concentrations near the current ADL values are of higher priority than those analytes estimated to be in quantities above their ADL. Once the list of analytes with suspect ADLs is prioritized by comparison with estimated quantities in the SSTs, the Type I, II, and III categories can be used in the effort to further prioritize the ADLs.

Tables 5.5 to 5.7 summarize the data on DLGs, ADLs, and 241-B-110 tank concentrations for 40 SST analytes with suspect ADLs (the other 60 analytes 


\section{Input}

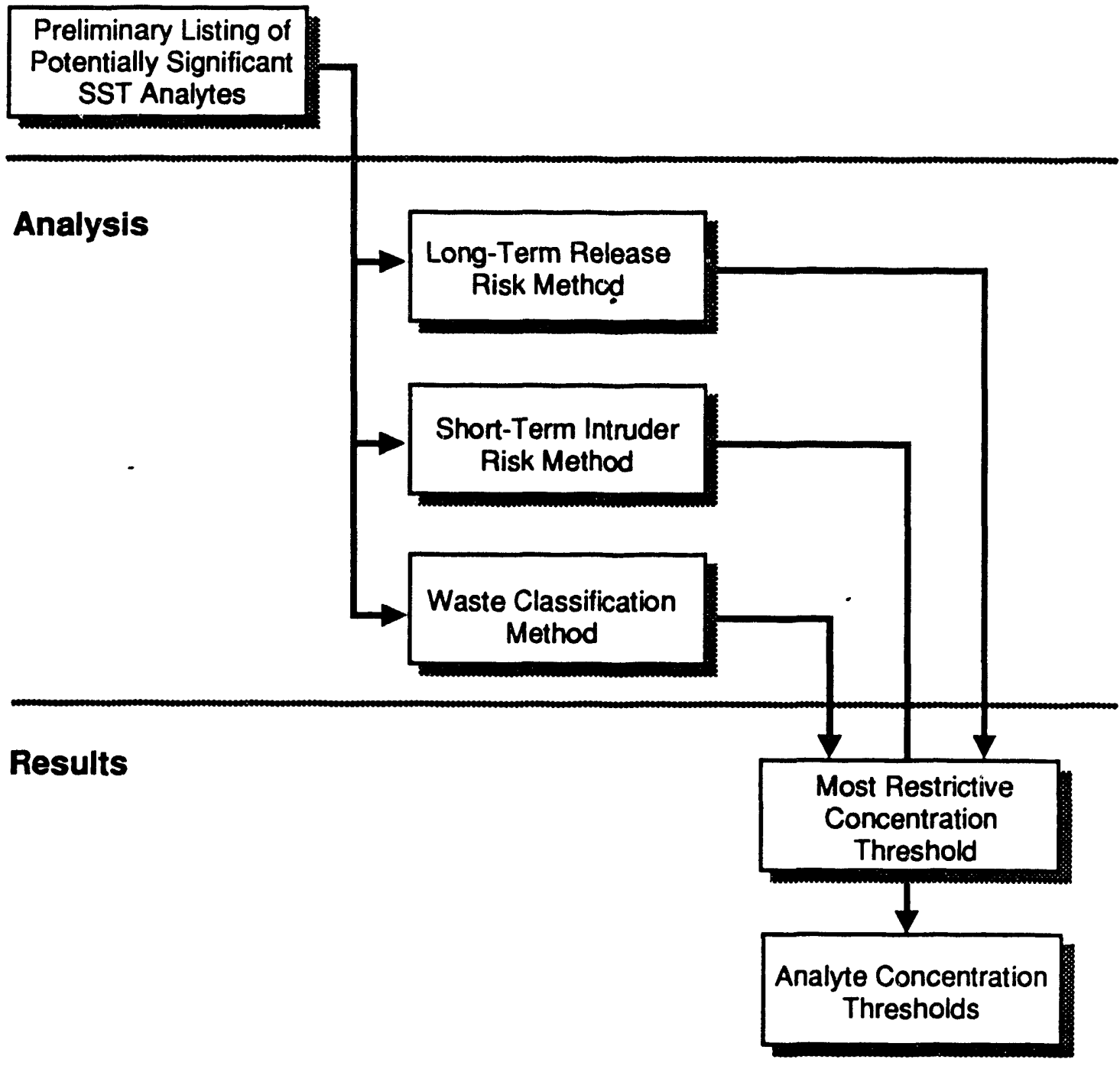

R9012111.3

FIGURE 5.3. Diagram of the Relationship Between the Single-Shell Tank Analyte Ranking, Concentration Threshold Values, and Proposed Detection Limit Goals Using All Three Methods

have adequate $A D(S)$. The mor? detailed information on the DLGs by analyte priority type is provided in Appendix F. Table 5.5 contains detection limit and tank concentration data for suspect analytes that are in large (with respect to the $A D L)$ quantities in reference tank $241-B-110$ and TRAC inventory estimates. Although 211 of these analytes are Type $I$, they are estimated to 
IABLE 5.5. Single-Shell Tank Analytes with Suspect Analytical Detection Limits that Appear to be in Large Quantities

\begin{tabular}{|c|c|c|c|c|c|}
\hline Analyte & $\begin{array}{c}\text { Priority } \\
\text { Type }\end{array}$ & $\begin{array}{l}\text { Detection } \\
\text { Limit Goal } \\
(\mu \mathrm{Ci} / \mathrm{g} \text { or } \\
\mu \mathrm{g} / \mathrm{g}) \\
\end{array}$ & $\begin{array}{c}\text { Analytical } \\
\text { Detection } \\
\text { Limit } \\
(\mu \mathrm{Ci} / \mathrm{g} \text { or } \\
\mu \mathrm{g} / \mathrm{g}) \\
\end{array}$ & $\begin{array}{c}\text { Measured } \\
241-\mathrm{B}-110 \\
\text { Concentration }(\mathrm{b}) \\
(\mu \mathrm{Ci} / \mathrm{g} \text { or } \mu \mathrm{g} / \mathrm{g})\end{array}$ & $\begin{array}{c}\text { TRAC } \\
241-\mathrm{B}-110 \\
\text { Concentration } \\
(\mu \mathrm{C} / \mathrm{g} \text { or } \mu \mathrm{g} / \mathrm{g})\end{array}$ \\
\hline $\begin{array}{l}{ }^{241} \mathrm{Am} \\
{ }^{238} \mathrm{Pu} \\
{ }^{239} \mathrm{Pu} \\
{ }^{246} \mathrm{Pu} \\
{ }^{99} \mathrm{TC} \\
{ }^{238} \mathrm{U} \\
{ }^{\mathrm{Al}} \\
\mathrm{Cr}+6 \\
\text { EDTA } \\
\mathrm{HEDTA} \\
\mathrm{F} \\
\mathrm{Ni} \\
\mathrm{NO}_{2} \\
\mathrm{NO}_{3} \\
\mathrm{SiO}_{3}\end{array}$ & $\begin{array}{l}I \\
I \\
I \\
I \\
I \\
I \\
I \\
I \\
I \\
I \\
I \\
I \\
I \\
I \\
I\end{array}$ & $\begin{array}{l}3.0 \mathrm{E}-05 \\
3.0 \mathrm{E}-05 \\
3.0 \mathrm{E}-05 \\
3.0 \mathrm{E}-05 \\
1.4 \mathrm{E}-06 \\
6.8 \mathrm{E}-08 \\
6.3 \mathrm{E}+00 \\
7.9 \mathrm{E}-02 \\
8.8 \mathrm{E}-04 \\
4.4 \mathrm{E}+01 \\
1.1 \mathrm{E}+00 \\
3.9 \mathrm{E}+00 \\
4.3 \mathrm{E}-02 \\
9.4 \mathrm{E}-01 \\
1.3 \mathrm{E}+01\end{array}$ & $\begin{array}{l}4.0 \mathrm{E}-04 \\
7.0 \mathrm{E}-05 \\
7.0 \mathrm{E}-05 \\
7.0 \mathrm{E}-05 \\
9.0 \mathrm{E}-04 \\
2.0 \mathrm{E}-07 \\
1.3 \mathrm{E}+01 \\
5.7 \mathrm{E}+00 \\
5.0 \mathrm{E}+01(\mathrm{e}) \\
5.0 \mathrm{E}+011^{(e)} \\
2.0 \mathrm{E}+01(\mathrm{e}) \\
5.0 \mathrm{E}+00 \\
4.0 \mathrm{E}+01^{(e)} \\
4.0 \mathrm{E}+01^{(e)} \\
1.5 \mathrm{E}+01\end{array}$ & $\begin{array}{l}7.3 \mathrm{E}-02 \\
2.9 \mathrm{E}-03^{(c)} \\
1.1 \mathrm{E}-01^{(c)} \\
1.3 \mathrm{E}-02^{(c)(d)} \\
1.8 \mathrm{E}-02^{(c)} \\
7.2 \mathrm{c}-05^{(c)} \\
2.7 \mathrm{c}+03 \\
2.3 \mathrm{E}+03 \\
9.5 \mathrm{E}+02^{(f)} \\
\mathrm{NA}^{(\mathrm{g})} \\
1.9 \mathrm{E}+03^{(c)} \\
1.2 \mathrm{c}+04 \\
1.0 \mathrm{E}+04^{(c)} \\
1.9 \mathrm{c}+05^{(c)} \\
6.0 \mathrm{C}+04\end{array}$ & $\begin{array}{l}3.6 \mathrm{E}-01 \\
3.5 \mathrm{E}-03 \\
6.8 \mathrm{E}-02 \\
1.7 \mathrm{E}-02 \\
1.0 \mathrm{E}-01 \\
2.3 \mathrm{E}-03 \\
2.7 \mathrm{E}+03 \\
5.3 \mathrm{E}+02 \\
0.0 \mathrm{E}+00 \\
0.0 \mathrm{E}+00 \\
5.8 \mathrm{E}+00 \\
1.5 \mathrm{E}+02 \\
0.0 \mathrm{E}+00 \\
1.1 \mathrm{E}+05 \\
5.2 \mathrm{E}+00\end{array}$ \\
\hline
\end{tabular}

(a) ADLs based on acid leach for chemical and fusion for radionuclides unless noted otherwise.

(b) All measurements are based on dry weight data unless noted otherwise.

(c) Measurement based on wet weight data.

(d) Calculated from ${ }^{248} \mathrm{Pu} /{ }^{239} \mathrm{Pu}$ mass ratio and assumes that the specific activity of the mass ratio is the same as ${ }^{239} \mathrm{Pu}$.

(e) ADL is based on water leach method.

(f) $A D L$ is based on water leach method for total organic content (TOC).

(g) NA indicates data or method is not available.

be in quantities in SSTs well above detection limits and, therefore, are low priority for ADL modification compared with analytes in Tables 5.6 and 5.7. Table 5.6 shows suspect SST analytes that are estimated to be in small quantities based on measured 241-B-110 and TRAC data. These analytes are the top priority for ADL modification because tank concentrations are estimated to be near the ADL. For the analytes in Table 5.6, the Type I analytes should be evaluated and their analytical measurement techniques modified first, then the Type II and III analytes can be done. Table 5.7 shows nine Type I and II analytes that do not have ADLs adequately defined (noted as TBD). These analytes should be evaluated after the analytes in Table 5.6 but before the 
TABLE 5.6. Single-Shell Tank Analytes with Suspect Analytical Detection Limits that Appear to be in Small Quantities $(a)$

\begin{tabular}{|c|c|c|c|c|c|}
\hline Analyte & $\begin{array}{c}\text { Priority } \\
\text { Type }\end{array}$ & $\begin{array}{l}\text { Detection } \\
\text { Limit Goal } \\
(\mu \mathrm{Ci} / \mathrm{g} \text { or } \\
\mu \mathrm{g} / \mathrm{g}) \\
\end{array}$ & $\begin{array}{c}\text { Analytical } \\
\text { Detection } \\
\text { Limit } \\
(\mu \mathrm{Ci} / \mathrm{g} \text { or } \\
\mu \mathrm{g} / \mathrm{g}) \\
\end{array}$ & $\begin{array}{c}\text { Measured } \\
241-\mathrm{B}-110 \\
\text { Concentration }^{(b)} \\
(\mu \mathrm{Ci} / \mathrm{g} \text { or } \mu \mathrm{g} / \mathrm{g})\end{array}$ & $\begin{array}{c}\text { TRAC } \\
241-\mathrm{B}-110 \\
\text { Concentration } \\
(\mu \mathrm{Ci} / \mathrm{g} \text { or } \mu \mathrm{g} / \mathrm{g})\end{array}$ \\
\hline $\begin{array}{l}{ }^{242 \mathrm{~m}} \mathrm{Am} \\
{ }^{14} \mathrm{C} \\
{ }^{129} \mathrm{I} \\
\mathrm{Ba} \\
\mathrm{Cd}^{243} \mathrm{Am} \\
{ }^{244} \mathrm{Cm} \\
{ }^{237} \mathrm{~Np} \\
{ }_{27} \\
{ }^{245} \mathrm{Cm} \\
\mathrm{SeO}_{4} \\
\mathrm{As} \\
\mathrm{V}\end{array}$ & $\begin{array}{l}\text { I } \\
\text { I } \\
\text { I } \\
\text { I } \\
\text { I } \\
\text { I I } \\
\text { I I } \\
\text { I I } \\
\text { II I } \\
\text { II I } \\
\text { II I } \\
U_{U^{(f)}} \\
U^{(f)}\end{array}$ & $\begin{array}{l}3.0 \mathrm{E}-05 \\
6.4 \mathrm{E}-06 \\
2.1 \mathrm{E}-08 \\
8.7 \mathrm{E}-01 \\
5.3 \mathrm{E}-01 \\
3.0 \mathrm{E}-05 \\
3.0 \mathrm{E}-05 \\
-3.0 \mathrm{E}-05 \\
1.1 \mathrm{E}+00 \\
3.0 \mathrm{E}-05 \\
2.9 \mathrm{E}-01 \\
1.7 \mathrm{E}-03 \\
4.9 \mathrm{E}-01\end{array}$ & $\begin{array}{l}1.0 E-04 \\
5.0 E-05^{(d)} \\
7.0 E-06^{(d)} \\
9.2 E-01 \\
1.6 E+00 \\
7.0 E-03 \\
4.0 E-04 \\
4.8 E-05^{(d)(g)} \\
2.0 E+011^{(d)} \\
2.0 E-01 \\
5.0 E-01 \\
7.0 E-03 \\
2.7 E+00\end{array}$ & $\begin{array}{l}N^{(c)} \\
4.0 \mathrm{E}-04^{(e)} \\
3.0 \mathrm{E}-05^{(e)} \\
9.7 \mathrm{E}+00 \\
4.1 \mathrm{E}+\mathrm{Q}{ }^{1} \\
\mathrm{NA}(\mathrm{c}) \\
8.6 \mathrm{E}-04^{(e)} \\
1.2 \mathrm{E}-04(\mathrm{e}) \\
1.3 \mathrm{E}+03^{(e)} \\
\mathrm{NA}(\mathrm{c}) \\
1.8 \mathrm{E}+02 \\
5.6 \mathrm{E}+01 \\
3.5 \mathrm{E}+02\end{array}$ & $\begin{array}{l}1.4 \mathrm{E}-03 \\
3.4 \mathrm{E}-02 \\
1.7 \mathrm{E}-04 \\
4.7 \mathrm{E}+00 \\
0.0 \mathrm{E}+00 \\
6.8 \mathrm{E}-04 \\
3.4 \mathrm{E}-03 \\
1.0 \mathrm{E}-05 \\
0.0 \mathrm{E}+00 \\
3.4 \mathrm{E}-07 \\
0.0 \mathrm{E}+00 \\
N A \text { (c) } \\
N A^{(c)}\end{array}$ \\
\hline
\end{tabular}

(a) ADLs based on acid leach for chemical and fusion for radionuclides unless noted otherwise.

(b) All measurements are based on dry weight data unless noted otherwise.

(c) NA indicates data or method is not available.

(d) ADL is based on water leach method.

(e) Measurement based on wet weight data.

(f) $U$ indicates analyte unranked because of lack of inventory data.

(g) ${ }^{237} \mathrm{~Np}$ detection limit is based on the percent of error on Tank B-110 measurements. 
TABLE 5.7. Important Analytes that Need Analytical Detection Limits to be Determined ${ }^{(a)}$

\begin{tabular}{|c|c|c|c|c|c|}
\hline Analyte & $\begin{array}{c}\text { Priority } \\
\text { Type }\end{array}$ & $\begin{array}{l}\text { Detection } \\
\text { Limit Goal } \\
(\mu \mathrm{C} / \mathrm{g} \text { or } \\
\mu \mathrm{g} / \mathrm{g}) \\
\end{array}$ & $\begin{array}{l}\text { Analytical } \\
\text { Detection } \\
\text { Limit } \\
(\mu \mathrm{C} / \mathrm{g} \text { or } \\
\mu \mathrm{g} / \mathrm{g}) \\
\end{array}$ & $\begin{array}{c}\text { Measured } \\
241-\mathrm{B}-110 \\
\text { Concentration (b) } \\
(\mu \mathrm{C} i / \mathrm{g} \text { or } \mu \mathrm{g} / \mathrm{g})\end{array}$ & $\begin{array}{c}\text { TRAC } \\
241-B-110 \\
\text { Concentration } \\
(\mu \mathrm{Ci} / \mathrm{g} \text { or } \mu \mathrm{g} / \mathrm{g})\end{array}$ \\
\hline${ }^{63} \mathrm{Ni}$ & I & $5.8 E-03$ & $\mathrm{TBD}^{(\mathrm{c})}$ & $N A^{(d)}$ & 7.0E-01 \\
\hline${ }^{96} Y$ & I & $5.7 E-02$ & $\mathrm{TBD}^{(\mathrm{c})}$ & $N A^{(d)}$ & $2.2 E-01$ \\
\hline $\mathrm{C}_{6} \mathrm{H}_{5} \mathrm{O}_{7}$ & I & $4.4 E+02$ & $\mathrm{TBD}^{(\mathrm{c})}$ & $N A^{(d)}$ & $3.2 E+04$ \\
\hline $\mathrm{CN}$ & I & $3.8 E-03$ & $\mathrm{TBD}^{(\mathrm{c})}$ & $N A^{(d)}$ & $0.0 E+00$ \\
\hline $\begin{array}{l}\mathrm{CO}_{3} \\
\mathrm{Cu}\end{array}$ & $\begin{array}{l}I \\
U^{(e)}\end{array}$ & $\begin{array}{r}\text { 3. } 3 E+02 \\
T B D^{(c)}\end{array}$ & $\begin{array}{r}\mathrm{TBD}^{(\mathrm{c})} \\
\text { 4. } 1 \mathrm{E}+00\end{array}$ & $\begin{array}{c}N A^{(d)} \\
4.6 E+02\end{array}$ & $\begin{array}{c}0.0 E+00 \\
N A^{(d)}\end{array}$ \\
\hline $\mathrm{OH}$ & $I$ & $4.4 E+01$ & $\mathrm{TBD}^{(\mathrm{c})}$ & $N A^{(d)}$ & $5.8 E+03$ \\
\hline${ }^{93} \mathrm{Nb}$ & I I & $\mathrm{TBD}^{(c)}$ & $\mathrm{TBD}^{(\mathrm{c})}$ & $N A^{(d)}$ & $1.4 \mathrm{E}-02$ \\
\hline $\mathrm{C}_{2} \mathrm{H}_{3} \mathrm{O}_{3}$ & I I & $4.4 E+02$ & $T B D^{(c)}$ & $N A^{(d)}$ & $0.0 E+00$ \\
\hline $\mathrm{Fe}(\mathrm{CN})_{6}$ & $\mathrm{II}_{\mathrm{U}^{(e)}}$ & $\begin{array}{r}8.9 E+01 \\
T^{(c)}\end{array}$ & $\begin{array}{l}\mathrm{TBD}^{(\mathrm{c})} \\
2 \mathrm{~F}+00\end{array}$ & $\begin{array}{c}N A^{(d)} \\
58 F+02\end{array}$ & $\begin{array}{c}0.0 E+00 \\
N A(d)\end{array}$ \\
\hline & & IBD & $1.2 E+00$ & $5.8 E+02$ & $N A^{(0)}$ \\
\hline
\end{tabular}

(a) ADLs based on acid leach for chemical and fusion for radionuclides unless noted otherwise.

(b) All measurements are based on dry weight data unless noted otherwise.

(c) TBD indicates the value is to be determined.

(d) NA indicates data or method is not available.

(e) $U$ indicates analyte unranked because of lack of inventory data.

analytes in Table 5.5. This information is preliminary and is to be used until more data are obtained from the next set of tanks to be sampled. 


\subsection{REFERENCES}

10 CFR 61. 1982. U.S. Nuclear Regulatory Commission, "Land Disposal of Radioactive Waste." U.S. Code of Federal Regulations.

53 FR 12449. Apri1 14, 1988. U.S. Department of Energy (DOE), "Record of Decision for the Environmental Impact Statement for the Disposal of Hanford High-Level Transuranic Wastes." Federal Register.

Adams, M. R., L. Jensen, and W. W. Schulz. 1986. Preliminary Assessment of the TRAC Model as a Predictor of Key Radionuclide Inventories. RHO-RE-EV-89 P, Rockwell Hanford Operations, Richland, Washington.

Buck, J. W., B. L. Hoopes, and D. R. Friedrichs. 1989. Multimedia Environmental Pollutant Assessment System (MEPAS): Getting Started with MEPAS. PNL-7126, Pacific Northwest Laboratory, Richland, Washington.

Buh1, T. E., and W. R. Hansen. 1984. Estimating the Risks of Cancer Mortality and Genetic Defects Resulting from Exposures to Low Levels of Ionizing Radiation. LA-9893-MS, Los Alamos National Laboratory, Los Alamos, New Mexico.

CRC. 1988. CRC Handbook of Chemistry and Physics. CRC Press, Inc., West Palm Beach, Florida.

Doctor, P. G., T. M. Miley, and C. E. Cowan. 1990. Multimedia Environmental Pollutant Assessment System (MEPAS) Sensitivity Analysis of Computer Codes. PNL-7296, Pacific Northwest Laboratory, Richland, Washington.

Droppo, J. G., G. Whelan, J. W. Buck, D. L. Strenge, B. L. Hoopes, M. B. Walter, R. L. Knight, and S. M. Brown. 1989a. Supplemental Mathematical Formulations: The Multimedia Environmental Pollutant Assessment System (MEPAS). PNL-7201, Pacific Northwest Laboratory, Richland, Washington.

Droppo, J. G., D. L. Strenge, J. W. Buck, B. L. Hoopes, R. D. Brockhaus, M. B. Walter, and G. Whelan. 1989b. Multimedia Environmental Pollutant Assessment System (MEPAS) Application Guidance (Volume 1). PNL-7216 Vol. 1, Pacific Northwest Laboratory, Richland, Washington.

Droppo, J. G., D. L. Strenge, J. W. Buck, B. L. Hoopes, R. D. Brockhaus, M. B. Walter, and G. Whelan. 1989c. Multimedia Environmental Pollutant Assessment System (MEPAS) Application Guidance (Volume 2). PNL-7216 Vol. 2, Pacific Northwest Laboratory, Richland, Washington.

Droppo, J. G., J.W. Buck, D. L. Strenge, and M. R. Siegel. 1990. Analysis of Health Impact Inputs to the U.S. Department of Energy's Risk Information System. PNL-7432, Pacific Northwest Laboratory, Richland, Washington. 
Droppo, J. G., J. W. Buck, J. S. Wilbur, D. L. Strenge, and M. D. Freshley. 1991. Single-Shell Tank Constituent Rankings for Use in Preparing Waste Characterization Plans. PNL-7572, Pacific Northwest Laboratory, Richland, Washington.

Ecology/EPA/DOE. 1989. Hanford Federal Facility Agreement and Consent Order. State of Washington Department of Ecology, No. 89-54, U.S. Environmental Protection Agency Docket No. 1089-03-04-120.

Fecht, K. R., and W. H. Price. 1977a. Granulometric Data 241-A Tank Farm . Monitoring Well Sediments. RHO-LD-11, Rockwe11 Hanford Operations, Richland, Washington.

Fecht, K. R., and W. H. Price. 1977b. Granulometric Data 241-AX Tank Farm Monitoring Well Sediments. RHO-LD-12, Rockwell Hanford Operations, Richland, Washington.

Fecht, K. R., and W. H. Price. 1977c. Granulometric Data 241-B Tank Farm Monitoring Well Sediments. RHO-LD-13, Rockwell Hanford Operations, Richland, Washington.

Fecht, K. R., and W. H. Price. 1977d. Granulometric Data 241-BX Tank Farm Monitoring Well Sediments. RHO-LD-14, Rockwell Hanford Operations, Richland, Washington.

Fecht, K. R., and W. H. Price. 1977e. Granulometric Data 241-BY Tank Farm Monitoring Well Sediments. RHO-LD-15, Rockwell Hanford Operations, Richland, Washington.

Fecht, K. R., and W. H. Price. 1977f. Granulometric Data 241-C Tank Farm Monitoring Well Sediments. RHO-LD-16, Rockwell Hanford Operations, Richland, Washington.

Fecht, K. R., and W. H. Price. 1977g. Granulometric Data 241-S Tank Farm Monitoring Well Sediments. RHO-LD-17, Rockwe11 Hanford Operations, Richland, Washington.

Fecht, K. R., and W. H. Price. 1977h. Granulometric Data 241-SX Tank Farm Monitoring Well Sediments. RHO-LD-18, Rockwell Hanford Operations, Richland, Washington.

Fecht, K. R., and W. H. Price. 1977i. Granulometric Data 241-T Tank Farm Monitoring Well Sediments. RHO-LD-19, Rockwell Hanford Operations, Richland, Washington.

Fecht, K. R., and W. H. Price. 1977j. Granulometric Data 241-TX Tank Farm Monitoring Well Sediments. RHO-LD-20, Rockwell Hanford Operations, Richland, Washington. 
Fecht, K. R., and W. H. Price. 1977k. Granulometric Data 241-TY Tank Farm Monitoring Well Sediments. RHO-LD-21, Rockwell Hanford Operations, Richland, Washington.

Fecht, K. R., and W. H. Price. 19771. Granulometric Data 241-U Tank Farm Monitoring Well Sediments. RHO-LD-22, Rockwe11 Hanford Operations, Richland, Washington.

Jensen, L., and A. Liebetrau. 1988. Statistical Techniques for Characterizing Single-Shell Tank Wastes. WHC-SA-0348-FP, West inghouse Hanford Company, Richland, Washington.

Keller, J. F., M. G. Woodruff, A. J. Schmidt, P. L. Hendrickson, and K. B. Selby. 1989. Regulatory Requirements Important to Hanford Single-She 11 Tank Disposal Decisions. PNL-6821, Pacific Northwest Laboratory, Richland, Washington.

Klem, M. J. 1988. Inventories of Chemicals Used at Hanford Production Plants and Support Operations (1944-1980). WHC-EP-0172, Westinghouse Hanford Company, Richland, Washington.

Layton, D. W., B. J. Mallon, D. H. Rosenblatt, and M. J. Small. 1987. "Deriving Allowable Daily Intakes for System Toxicants Lacking Chronic Toxicity Data." Regulatory Toxicity and Pharmacology 7(1):96-112.

Morgan, L. G., W. W. Schulz, M. R. Adams, and K. W. Owens. 1988. Summary of Single-Shel1 Tank Waste Characterization: 1985-1987. WHC-EP-0075, Westinghouse Hanford Company, Richland, Washington.

National Academy of Science (NAS). 1990. Health Effects of Exposure to Low Levels of Ionizing Radiation: BEIR $V$. Committee on the Effects of Ionizing Radiations, National Research Counci1, Washington, D.C.

National Institute of Occupational Safety and Health (NIOSH). 1987. Registry of Toxic Effects of Chemical Substances: 1985-86 Edition, D. V. Sweet, ed. DHHS (NIOSH) Publication No. 87-114, NIOSH, U.S. Department of Health and Human Services, Washington, D.C.

Price, W. H., and K. R. Fecht. 1976a. Geology of the 241-A Tank Farm. ARHLD-127, Atlantic Richfield Hanford Company, Richland, Washington.

Price, W. H., and K. R. Fecht. 1976b. Geology of the 24l-AX Tank Farm. ARHLD-128, Atlantic Richfield Hanford Company, Richland, Washington.

Price, W. H., and K. R. Fecht. 1976c. Geology of the 241-B Tank Farm. ARHLD-129, Atlantic Richfield Hanford Company, Richland, Washington.

Price, W. H., and K. R. Fecht. 1976d. Geology of the 241-BX Tank Farm. ARHLD-130, Atlantic Richfield Hanford Company, Richland, Washington. 
Resource Conservation and Recovery Act (RCRA) of 1976. 42 USC 6901 et seq., as amended.

Schulz, W. W. 1978. Removal of Radionuclides from Hanford Defense Waste Solutions. RHO-SA-51, Rockwell Hanford Operations, Richland, Washington.

Serne, R. J., and M. I. Wood. 1990. Hanford Waste-Form Release and Sediment Interaction. PNL-7297, Pacific Northwest Laboratory, Richland, Washington.

Tallman, A. M., K. R. Fecht, M. C. Marratt, and G. V. Last. 1979. Geology of the Separation Areas, Hanford Site, South-Central Washington. RHO-ST-23, Rockwell Hanford Operations, Richland, Washington.

U.S. Department of Energy (DOE). 1987. Final Environmental Statement for Disposal of Hanford Defense, High-Level Transuranic and Tank Wastes.

DOE/EIS-0113, U.S. Department of Energy, Richland, Washington.

U.S. Department of Energy (DOE). 1988. Environmental Survey Prel iminary Summary Report of the Defense Production Facilities. DOE/EH-0072, U.S. Department of Energy, Office of Environment, Safety, and Health, Washington, D.C.

U.S. Environmental Protection Agency (EPA). 1989a. Risk Assessment Guidance for Superfund, Volume 1. Human Health Evaluation Manual (Part A). EPA/540/189/002, Official Emergency and Remedial Response, U.S. Environmental

Protection Agency, Washington D.C.

U.S. Environmental Protection Agency (EPA). 1989b. Reference Dose (Rfd): Description and Use in Health Risk Assessments. Appendix A to the Integrated Risk Information System (IRIS). U.S. EPA, Washington, D.C.

U.S. Nuclear Regulatory Commission (NRC). 1981a. Data Base for Radioactive Waste Management. NUREG/CR-1759, Washington, D.C.

U.S. Nuclear Regulatory Commission (NRC). 1981b. Draft Environmental Impact Statement on 10 CFR 61 , Licensing Requirements for Land Disposal of Radioactive Waste. NUREG-0782, Washington, D.C.

U.S. Nuclear Regulatory Commission (NRC). 1982. Final Environmental Impact Statement on 10 CFR 61 , Licensing Requirements for Land Disposal of Radioactive Waste. NUREG-0945, Washington, D.C.

U.S. Nuclear Regulatory Commission (NRC). 1986. Update of Part 61 Impacts Analys is Methodology. NUREG/CR-4370, Washington, D.C.

Washington State. 1987. Washington State Dangerous Waste Regulations. WAC-173-303-084, 01ympia, Washington.

Weiss, R. L. 1986. TY Tank Farm Waste Characterization Data. RHO-WM-TI-1P, Rockwell Hanford Operations, Richland, Washington. 
Whelan, G., D. L. Strenge, J. G. Droppo Jr., B. L. Steelman, and J. W. Buck. 1987. The Remedial Action Priority System (RAPS): Mathematical Formulations. PNL-6200, Pacific Northwest Laboratory, Richland, Washington.

Whelan, G., J. G. Droppo Jr., D. L. Strenge, M. B. Walter, and J. W. Buck. 1989. A Demonstration of the Applicability of Implementing the Enhanced Remedial Action Priority System (RAPS) for Environmental Releases. PNL-7102, Pacific Northwest Laboratory, Richland, Washington.

Winters, W. I., L. Jensen, L. M. Sasaki, R. L. Weiss, A. R. Keller, A. J. Schmidt, and M. G. Woodruff. 1989. Waste Characterization Plan for the Hanford Site Single-She11 Tanks. WHC-EP-0210 Rev. 0, Westinghouse Hanford Company, Richland, Washington.

Winters, W. I., L. Jensen, L. M. Sasaki, R. L. Weiss, J. F. Keller, A. J. Schmidt, and M. G. Woodruff. 1990. Waste Characterization Plan for the Hanford Site Single-She11 Tanks. WHC-EP-0210 Rev. 1, Westinghouse Hanford Company, Richland, Washington. 
-

APPENDIX A

DESCRIPTION OF LONG -TERM RELEASE RISK ANALYSE METHOD BY TANK FARM GROUP 
APPENDIX A

\section{DESCRIPTION OF LONG-TERM RELEASE RISK ANALYTE METHOD BY TANK FARM GROUP}

The Long-Term Release Risk (LTRR) scenario is based on estimates of potential public health impacts from groundwater usage at a hypothetical location. Initial characterization of the SST inventories, analyte release rates, environmental transport, and exposure scenarios were used as input to the Multimedia Environmental Pollutant Assessment System (MEPAS) (Whelan et a1. 1987; Droppo et al. 1989). For this assessment, the list of possible SST analytes includes those of potential health and regulatory concerns. A base list of analytes predicted with a TRAC computer simulation of SSTs inventories was supplemented with additional analytes that may (or are suspected to) be present in the SST wastes. Thus, the analytes in the SST wastes evaluated in this study include those that are known to be present, some that are suspected to be present, and some whose presence or absence needs to be defined as part of the characterization program. The characterization of SST wastes will be an iterative process; as characterization proceeds, future assessments will be more refined.

Based on information from past studies at the Hanford Site, it was determined that there are six geologic settings associated with the 12 SST farms. These six geologic settings represent different geologic and hydrologic conditions present beneath the SST farms. The 12 SST farms at Hanford were combined and considered as six tank farm groups designated as Tank Farm Groups $A$ ( $A$ and AX SST farms), B (B, BX, and BY SST farms), C (C SST farm), S ( $S$ and SX SST farms), $T$ ( $T$, TX, and TY SST farms), and $U$ (U SST farm). The 12 SST tank farms have been reorganized into six operable units (OUs) since this work was started. This requires modifications to inventories and as well as possible changes to geologic and hydrologic settings.

Three of the OUs contain the same SSTs as three of the tank farm groups (200-BP-7 = Tank Farm Group B, 200-RO-4 = Tank Farm Group S, and 200-UP-3 = 
Tank Farm Group U). In the future, SSTs waste characteristics will be analyzed based on OUs but for this current volume, the tank farm group categories will be used.

The release of the inventories for each tank farm group is based on a simplified waste form. All wastes from each tank farm group are assumed to be aggregated in a large underground tank with completely permeable walls. Wastes are then released to the environment though solubility-controlled releases, which assumes that infiltrating water contacts the waste form and carries analytes away from the source at their maximum solution concentration.

The transport of SST wastes in Hanford soils and groundwater was simulated with the groundwater component of MEPAS. Transport was predicted through the unsaturated and saturated zones to a hypothetical usage location represented by a well $50 \mathrm{~m}$ downgradient from each tank farm. Because the potential receptor population in the Hanford region actually occurs considerably farther downgradient, this approach is merely a convenient method of computing impacts with minimum dispersion for comparative purposes. Potential human haalth impacts were computed at the hypothetical usage location for each tank farm group out to 10,000 years in the future.

A standard Hanford "farm exposure scenario" (patterned after the Hanford Grout Performance Assessment documented in Sewart et a1. [1987]) involving direct human and agricultural usage (vegetable, meat, and milk) of well water was selected as a scenario that included all major exposure routes. This farm exposure scenario provides a means of computing potential health impacts for comparative purposes based on Hanford-area information.

The total health impact rankings from the farm exposure scenario for radioactive carcinogens, chemical carcinogens, and chemical noncarcinogens were reprrted in terms of a ranking index. The ranking index formulations for radioactive constituents $\left(R I_{R}\right)$, for carcinogenic constituents $\left(R I_{C}\right)$, and for noncarcinogenic constituents $\left(R I_{N}\right)$ are presented below. The dose computed for each constituent is based on the maximum water concentration for the modeling period. The ranking indexes are reported separately to reflect the different nature of impacts (i.e., carcinogens versus noncarcinogens) and fossible uncertainty in the equivalence of carcinogenic effects. 
For radionuclides, the ranking index is evaluated following EPA's general guidance for carcinogenic risk levels (EPA 1989) using an effective dose equivalent (EDE) for an individual exposed for a 70-year lifetime in a farming scenario. The health effects conversion factor $\left(H_{E}\right)$, expressed as risk per unit dose, was the value derived by Buhl and Hansen (1984) from NAS (1980).

$$
R I_{R}=(E D E) * H_{E}
$$

where $R I_{R}=$ ranking index for a radionuclide

$E D E$ = maximum effective dose equivalent for lifetime exposure for an individual, rem

$H_{E}=$ health effect conversion factor, $2.7 \times 10^{-4}$ health effects per rem lifetime exposure

For carcinogenic chemicals, the ranking index is evaluated consistent with EPA's guidance for carcinogenic risk levels (EPA 1989) using a chemicalpecific cancer potency factor.

$$
R I_{C}=D \times C P F
$$

where $R I_{C}=$ ranking index for a carcinogenic chemical

$D=$ maximum lifetime intake rate of a chemical $(\mathrm{mg} / \mathrm{kg} / \mathrm{d})$

$C F F=$ cancer potency factor for the chemical $(\mathrm{mg} / \mathrm{kg} / \mathrm{d})^{-1}$

The ranking indexes for radionuclides and carcinogenic chemicals are approximately comparable because both are based on estimates of latent cancer fatalities. The ranking index for noncarcinogenic chemicals, on the other hand, is not related to any specific fatal effect.

The noncarcinogen ranking index is evaluated following EPA's guidance for noncarcinogenic hazard quotients (EPA 1989):

$$
R I_{N}=D / R f D
$$


where $R I_{v}=$ ranking index for a noncarcinogenic chemical

$D=$ maximum iffetine average rate of a chemical, $\mathrm{mg} / \mathrm{kg} / \mathrm{d}$

$R f D=$ reference dose for the chemical, $\mathrm{mg} / \mathrm{kg} / \mathrm{d}$

The reference dose is an intake level that represents a safe level of intake for continuous exposure over the lifetime of an individual.

Indexes for both radioactive and chemical carcinogens are based on similar risk-based considerations. On these scales, the EPA often uses a value of $10^{-5}$ as an acceptable level of protection.

The impacts of noncarcinogens are normally assumed to occur only at concentrations greater than some threshold value. The scale for the noncarcinogenic ranking index is such that a value equal to or less than 1.0 indicates the comited levels for the hypothetical exposure scenario are below those at which effects are expected.

A combined rankin: index was computed for parent radionuclides and tine ir decay products. The decay products were evaluated separately to account for individual transport properties, and these doses were combined with the parent to provide a complete ranking index for the parent radionuclide and its decay products. The ranking indexes computed at 10,000 years were approximated by scaling this result with decay-chain-predicted inventories for the next 10,000 years. This procedure allowed simulation of relatively fast-moving decay products that are produced by relatively slow-moving parents.

Tables A.1 through A.6 provide the analyte and cumulative risk indexes from the LTRR assessment. These indexes were used to rank analytes and to compute concentration threshold values based on chronic health impacts. Ethylenediaminetetraaceti: acid (EDTA) ranked as the most important noncarcinogenic analyte because of its large inventory as indicated by the TRAC code (EDTA has a relatively low toxicity value). It is thought that EDTA is not in its original form; the high temperatures in the tanks neutralize it and it forms strong metallic complexes. The high ranking of uranium isotopes $\left({ }^{233} U,{ }^{234} U,{ }^{235} U\right.$, and $\left.{ }^{238} U\right)$ as important carcinogenic analytes results mainly from the assumption that uranium is present in the uranyl carbonate form. This assumption makes them very mobile, resulting in conservative estimates of 
TABLE A.1. Long-Term Release Risk Method Risk Indexes for Noncarcinogen and Carcinogens in Tank Farm Group $A$

Non-Carcinogenic Analytes

\begin{tabular}{|c|c|c|c|}
\hline $\begin{array}{c}\text { Const ituent } \\
\text { Name }\end{array}$ & $\begin{array}{r}\text { Risk } \\
\text { Index } \\
\end{array}$ & $\begin{array}{c}\% \text { Total } \\
\text { Risk } \\
\end{array}$ & $\begin{array}{c}\text { Cumulative } \\
\% \text { Risk }\end{array}$ \\
\hline $\begin{array}{l}\text { Nitrite } \\
\text { Nitrate } \\
\text { Cyanide Ion } \\
\text { Fluoride } \\
\text { Sodium Ion } \\
\text { Sulfate } \\
\text { Chromium VI } \\
\text { Nickel } \\
\text { Silver } \\
\text { Chloride } \\
\text { Iron } \\
\text { Cumulative Risk }\end{array}$ & $\begin{array}{l}1.00 E+04 \\
3.90 E+02 \\
1.70 E+01 \\
1.40 E+01 \\
5.40 E+00 \\
3.00 E+00 \\
3.20 E-01 \\
1.00 E-04 \\
1.20 E-06 \\
3.40 E-08 \\
1.60 E-08 \\
1.04 E+04\end{array}$ & $\begin{array}{l}95.880 \\
3.739 \\
1.63 \mathrm{E}-01 \\
1.34 \mathrm{E}-01 \\
5.18 \mathrm{E}-22 \\
2.88 \mathrm{E}-0 \mathrm{C} \\
3.07 \mathrm{E}-03 \\
9.59 \mathrm{E}-07 \\
1.15 \mathrm{E}-08 \\
3.26 \mathrm{E}-10 \\
1.53 \mathrm{E}-10 \\
100.00\end{array}$ & $\begin{array}{r}95.88 \\
99.62 \\
99.78 \\
99.92 \\
99.97 \\
100.00 \\
100.00 \\
100.00 \\
100.00 \\
100.00 \\
100.00\end{array}$ \\
\hline EDTA & $1.40 E+04$ & included & umulative $r$ \\
\hline
\end{tabular}

Carcinogenic Analytes

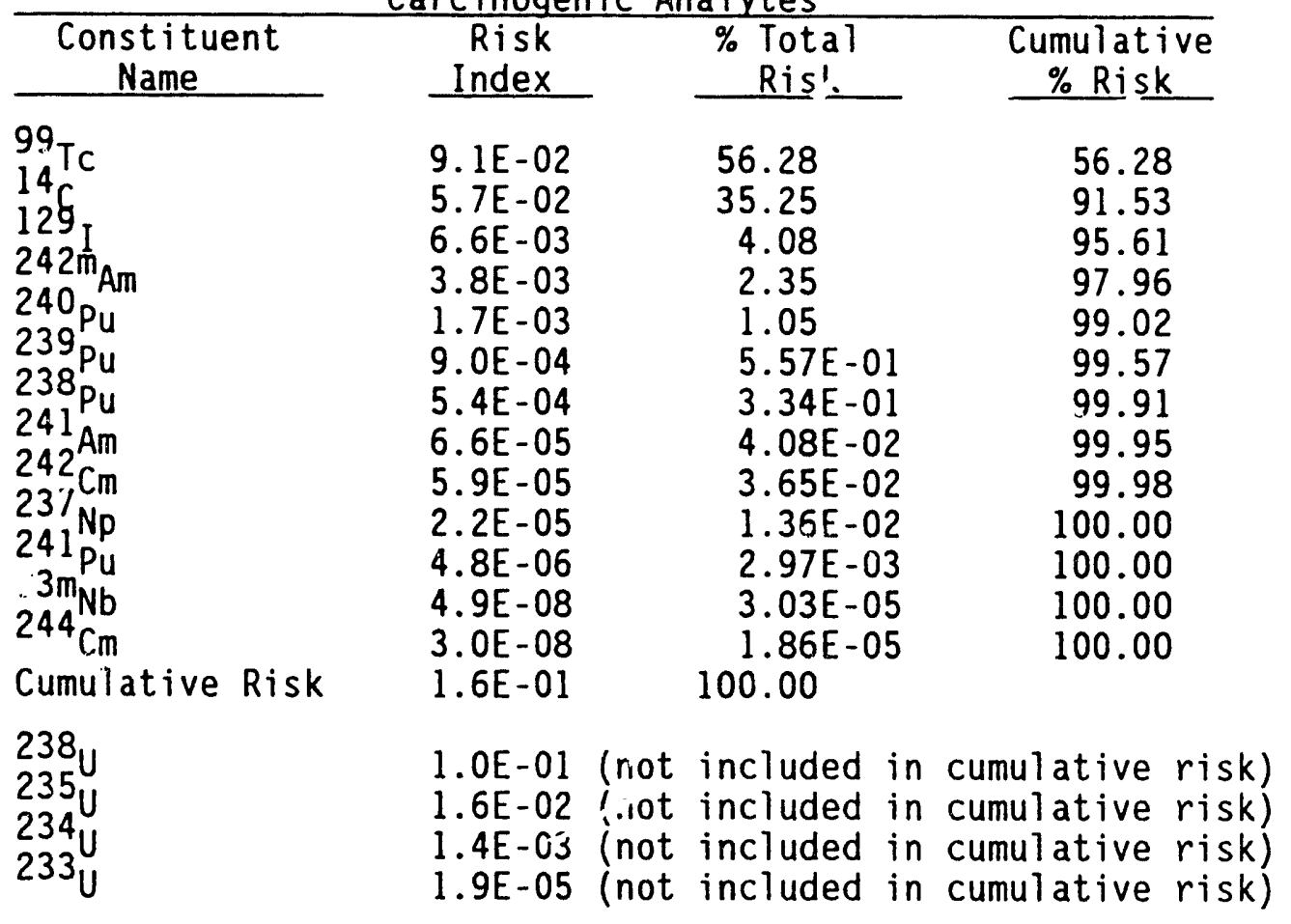


TABLE A.2. Long-Term Release Risk Method Risk Indexes for Noncarcinogen and Carcinogens in Tank Farm Group B

Non-Carcinogenic Analytes

\begin{tabular}{|c|c|c|c|}
\hline $\begin{array}{c}\text { Constituent } \\
\text { Name }\end{array}$ & $\begin{array}{r}\text { Risk } \\
\text { Index } \\
\end{array}$ & $\begin{array}{c}\% \text { Total } \\
\text { Risk } \\
\end{array}$ & $\begin{array}{c}\text { Cumulative } \\
\% \text { Risk }\end{array}$ \\
\hline $\begin{array}{l}\text { Nitrite } \\
\text { Fluoride } \\
\text { Nitrate } \\
\text { Cyanide Ion } \\
\text { Sodium Ion } \\
\text { Chromium VI } \\
\text { Sulfate } \\
\text { Nickel } \\
\text { Silver } \\
\text { Chloride } \\
\text { Iron } \\
\text { Cumulative Risk }\end{array}$ & $\begin{array}{l}1.40 \mathrm{E}+05 \\
2.30 \mathrm{E}+03 \\
4.90 \mathrm{E}+02 \\
1.50 \mathrm{E}+02 \\
5.50 \mathrm{E}+01 \\
3.90 \mathrm{E}+00 \\
1.60 \mathrm{E}+00 \\
8.80 \mathrm{E}-03 \\
5.80 \mathrm{E}-05 \\
5.00 \mathrm{E}-07 \\
4.40 \mathrm{E}-07 \\
1.43 \mathrm{E}+05\end{array}$ & $\begin{array}{c}97.90 \\
1.61 \\
3.43 \mathrm{E}-01 \\
1.05 \mathrm{E}-01 \\
3.85 \mathrm{E}-02 \\
2.73 \mathrm{E}-03 \\
1.12 \mathrm{E}-03 \\
6.15 \mathrm{E}-06 \\
4.06 \mathrm{E}-08 \\
3.50 \mathrm{E}-10 \\
3.08 \mathrm{E}-10 \\
100.00\end{array}$ & $\begin{array}{r}97.90 \\
99.51 \\
99.85 \\
99.96 \\
100.00 \\
100.00 \\
100.00 \\
100.00 \\
100.00 \\
100.00 \\
100.00\end{array}$ \\
\hline EDTA & $1.60 E+04$ & included & umulative $r$ \\
\hline
\end{tabular}

Carcinogenic Analytes

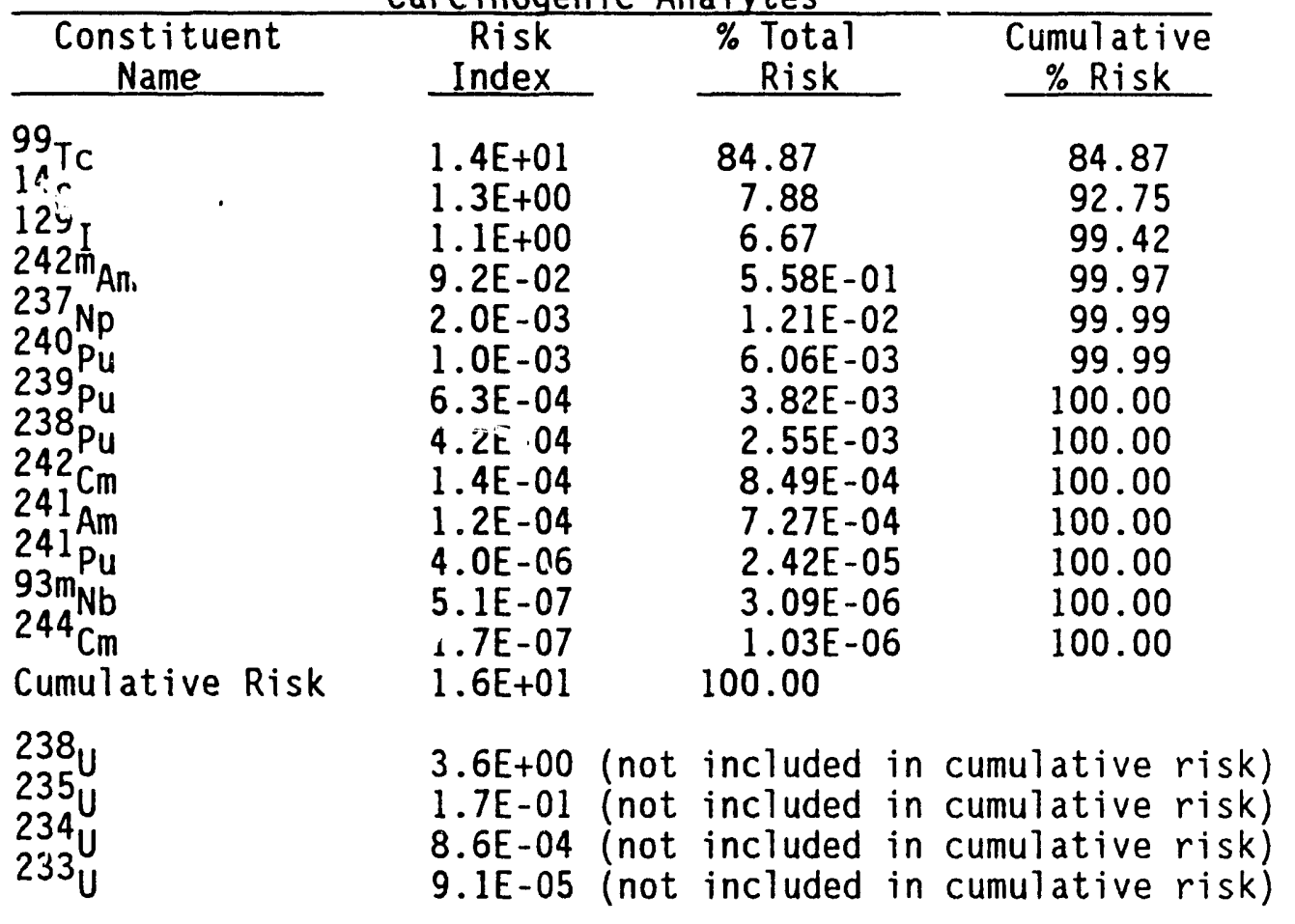


TABLE A.3. Long-Term Release Risk Method Risk Indexes for Noncarcinogen and Carcinogens in Tank Farm Group C

Non-Carcinogenic Analytes

\begin{tabular}{|c|c|c|c|}
\hline $\begin{array}{c}\text { Constituent } \\
\text { Name }\end{array}$ & $\begin{array}{r}\text { Risk } \\
\text { Index } \\
\end{array}$ & $\begin{array}{c}\% \text { Total } \\
\text { Risk } \\
\end{array}$ & $\begin{array}{c}\text { Cumulative } \\
\% \text { Risk } \\
\end{array}$ \\
\hline $\begin{array}{l}\text { Fluoride } \\
\text { Nitrite } \\
\text { Nitrate } \\
\text { Cyanide Ion } \\
\text { Sodium Ion } \\
\text { Sulfate } \\
\text { Chromium VI } \\
\text { Nickel } \\
\text { Silver } \\
\text { Iron } \\
\text { Chloride } \\
\text { Cumulative Risk }\end{array}$ & $\begin{array}{l}1.60 E+03 \\
5.00 E+02 \\
4.90 E+02 \\
1.50 E+02 \\
9.70 E+00 \\
3.10 E-01 \\
1.10 E-01 \\
1.50 E-04 \\
3.00 E-06 \\
6.60 E-09 \\
1.90 E-09 \\
2.75 E+03\end{array}$ & $\begin{array}{l}58.18 \\
18.18 \\
17.82 \\
5.45 \\
3.53 \mathrm{E}-01 \\
1.13 \mathrm{E}-02 \\
4.00 \mathrm{E}-03 \\
5.45 \mathrm{E}-06 \\
1.09 \mathrm{E}-07 \\
2.40 \mathrm{E}-10 \\
6.91 \mathrm{E}-11 \\
100.00\end{array}$ & $\begin{array}{r}58.18 \\
76.36 \\
94.18 \\
99.63 \\
99.98 \\
100.00 \\
100.00 \\
100.00 \\
100.00 \\
100.00 \\
100.00\end{array}$ \\
\hline EDTA & $3.30 E+03$ & included & umulative \\
\hline
\end{tabular}

Carcinogenic Analytes

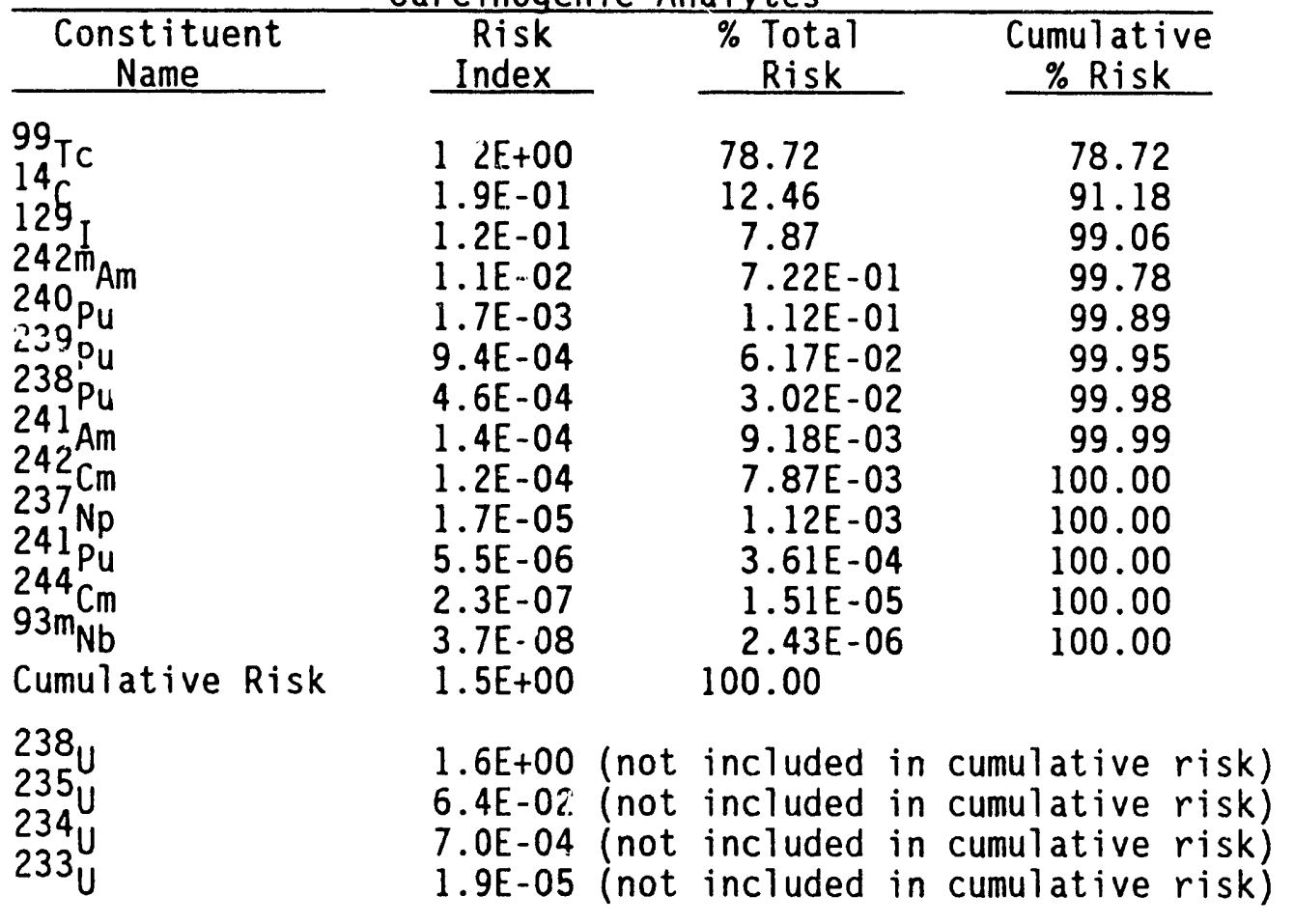


IABLE A.4. Long-Term Release Risk Method Risk Indexes for Noncarcinogen and Carcinogens in Tank Farm Group $S$

Non-Carcinogenic Analytes

\begin{tabular}{|c|c|c|c|}
\hline $\begin{array}{c}\text { Constituent } \\
\text { Name }\end{array}$ & $\begin{array}{r}\text { Risk } \\
\text { Index } \\
\end{array}$ & $\begin{array}{c}\% \text { Total } \\
\text { Risk } \\
\end{array}$ & $\begin{array}{c}\text { Cumulative } \\
\% \text { Risk }\end{array}$ \\
\hline $\begin{array}{l}\text { Nitrite } \\
\text { Chromium VI } \\
\text { Fluoride } \\
\text { Nitrate } \\
\text { Cyanide Ion } \\
\text { Sodium Ion } \\
\text { Nickel } \\
\text { Iron } \\
\text { Sulfate } \\
\text { Silver } \\
\text { Chloride } \\
\text { Cumulative Risk }\end{array}$ & $\begin{array}{l}3.20 E+05 \\
1.20 E+04 \\
1.80 E+03 \\
4.90 E+02 \\
1.50 E+02 \\
5.50 E+01 \\
1.00 E+01 \\
6.30 E+00 \\
4.30 E+00 \\
8.70 E-05 \\
1.70 E-56 \\
3.35 E+05\end{array}$ & $\begin{array}{c}95.66 \\
3.59 \\
5.38 \mathrm{E}-01 \\
1.46 \mathrm{E}-01 \\
4.48 \mathrm{E}-02 \\
1.64 \mathrm{E}-02 \\
2.99 \mathrm{E}-03 \\
1.88 \mathrm{E}-03 \\
1.29 \mathrm{E}-03 \\
2.60 \mathrm{E}-08 \\
5.08 \mathrm{E}-10 \\
100.00\end{array}$ & $\begin{array}{r}95.66 \\
99.25 \\
99.79 \\
99.93 \\
99.98 \\
99.99 \\
100.00 \\
100.00 \\
100.00 \\
100.00 \\
100.00\end{array}$ \\
\hline EDTA & $3.80 E+04$ & included & umulative $r$ \\
\hline
\end{tabular}

Carcinogenic Analytes

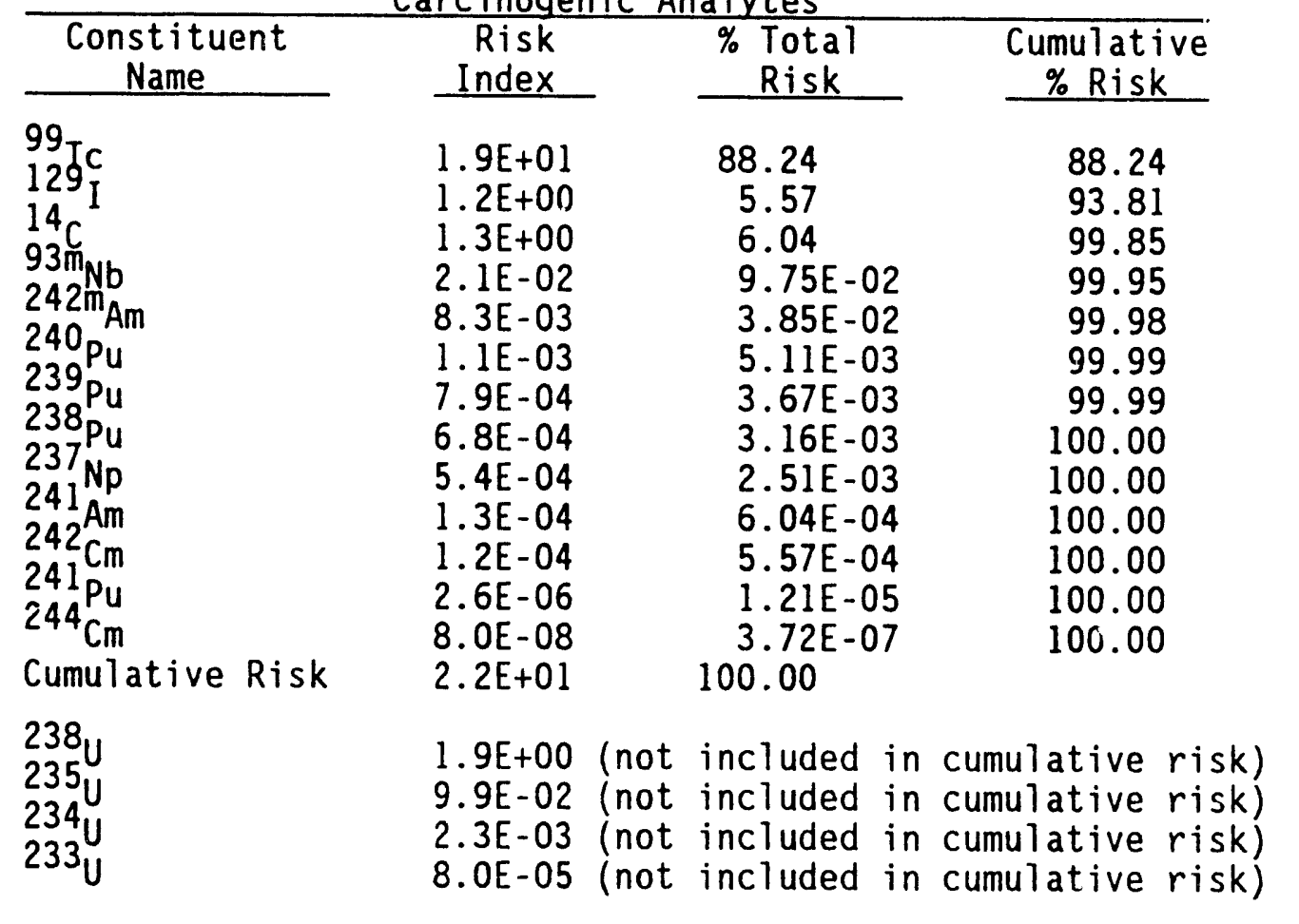


TABLE A.5. Long-Term Release Risk Method Risk Indexes for Noncarcinogen and Carcinogens in Tank Farm Group $T$

Non-Carcinogenic Analytes

\begin{tabular}{|c|c|c|c|}
\hline $\begin{array}{c}\text { Constituent } \\
\text { Name }\end{array}$ & $\begin{array}{r}\text { Risk } \\
\text { Index } \\
\end{array}$ & $\begin{array}{c}\% \text { Total } \\
\text { Risk }\end{array}$ & $\begin{array}{c}\text { Cumulative } \\
\% \text { Risk }\end{array}$ \\
\hline $\begin{array}{l}\text { Nitrite } \\
\text { Fluoride } \\
\text { Nitrate } \\
\text { Chromium VI } \\
\text { Cyanide Ion } \\
\text { Sodium Ion } \\
\text { Nickel } \\
\text { Sulfate } \\
\text { Iron } \\
\text { Silver } \\
\text { Chloride } \\
\text { Cumulative Risk }\end{array}$ & $\begin{array}{l}3.50 E+05 \\
3.80 E+03 \\
4.90 E+02 \\
2.90 E+02 \\
1.50 E+02 \\
5.50 E+01 \\
7.00 E+00 \\
4.30 E+00 \\
5.90 E-01 \\
3.80 E-05 \\
5.10 E-06 \\
3.55 E+05\end{array}$ & $\begin{array}{c}98.65 \\
1.07 \\
1.38 \mathrm{E}-01 \\
8.17 \mathrm{E}-02 \\
4.23 \mathrm{E}-02 \\
1.55 \mathrm{E}-02 \\
1.97 \mathrm{E}-03 \\
1.21 \mathrm{E}-03 \\
1.66 \mathrm{E}-04 \\
1.07 \mathrm{E}-08 \\
1.44 \mathrm{E}-09 \\
100.00\end{array}$ & $\begin{array}{r}98.65 \\
99.72 \\
99.86 \\
99.94 \\
99.98 \\
100.00 \\
100.00 \\
100.00 \\
100.00 \\
100.00 \\
100.00\end{array}$ \\
\hline EDTA & $3.80 E+04$ & included & umulative $r$ \\
\hline
\end{tabular}

\section{Carcinogenic Analytes}

\begin{tabular}{|c|c|c|c|}
\hline $\begin{array}{l}\text { Constituent } \\
\text { Name }\end{array}$ & $\begin{array}{r}\text { Risk } \\
\text { Index } \\
\end{array}$ & $\begin{array}{c}\% \text { Total } \\
\text { Risk }\end{array}$ & $\begin{array}{c}\text { Cumulative } \\
\% \text { Risk }\end{array}$ \\
\hline $\begin{array}{l}99 \\
14 \mathrm{Tc} \\
129 \mathrm{I} \\
242 \mathrm{~m}_{\mathrm{Am}} \\
93 \mathrm{~m}_{\mathrm{Nb}} \\
240 \mathrm{Pu} \\
239 \mathrm{Pu} \\
238 \mathrm{Pu} \\
237 \mathrm{Pu} \\
242 \mathrm{~Np} \\
241_{\mathrm{Cm}} \\
241_{\mathrm{Pu}} \\
244 \mathrm{Cm} \\
\text { Cumulative Risk }\end{array}$ & $\begin{array}{l}2.3 \mathrm{E}+01 \\
2.1 \mathrm{E}+00 \\
1.5 \mathrm{E}+00 \\
1.3 \mathrm{E}-03 \\
1.1 \mathrm{E}-03 \\
5.8 \mathrm{E}-04 \\
4.9 \mathrm{E}-04 \\
4.6 \mathrm{E}-04 \\
4.4 \mathrm{E}-04 \\
2.3 \mathrm{E}-04 \\
3.0 \mathrm{E}-05 \\
1.8 \mathrm{E}-06 \\
1.1 \mathrm{E}-08 \\
2.7 \mathrm{E}+01\end{array}$ & $\begin{array}{l}86.45 \\
7.89 \\
5.64 \\
4.89 \mathrm{E}-03 \\
4.13 \mathrm{E}-03 \\
2.18 \mathrm{E}-03 \\
1.84 \mathrm{E}-03 \\
1.73 \mathrm{E}-03 \\
1.65 \mathrm{E}-03 \\
8.65 \mathrm{E}-04 \\
1.13 \mathrm{E}-04 \\
6.77 \mathrm{E}-06 \\
4.13 \mathrm{E}-08 \\
100.00\end{array}$ & $\begin{array}{r}86.45 \\
94.34 \\
99.98 \\
99.99 \\
99.99 \\
99.99 \\
100.00 \\
100.00 \\
100.00 \\
100.00 \\
100.00 \\
100.00 \\
100.00\end{array}$ \\
\hline $\begin{array}{l}238 \mathrm{U} \\
235 \mathrm{U} \\
234 \mathrm{U} \\
233 \mathrm{U}\end{array}$ & $\begin{array}{l}2.7 \mathrm{E}+01 \text { (not } \\
1.1 \mathrm{E}+00 \text { (not } \\
6.3 \mathrm{E}-03 \text { (not } \\
1.7 \mathrm{E}-04 \text { (not }\end{array}$ & $\begin{array}{l}\text { included in } \\
\text { included in } \\
\text { included in } \\
\text { included in }\end{array}$ & $\begin{array}{l}\text { umulative risk } \\
\text { umulative risk } \\
\text { umulative risk } \\
\text { umulative risk }\end{array}$ \\
\hline
\end{tabular}


TABLE A.6. Long-Term Release Risk Method Risk Indexes for Noncarcinogen and Carcinogens in Tank Farm Group $U$

Non-Carcinogenic Analytes

\begin{tabular}{|c|c|c|c|}
\hline $\begin{array}{c}\text { Constituent } \\
\text { Name }\end{array}$ & $\begin{array}{r}\text { Risk } \\
\text { Index } \\
\end{array}$ & $\begin{array}{c}\% \text { Total } \\
\text { Risk }\end{array}$ & $\begin{array}{c}\text { Cumulative } \\
\% \text { Risk }\end{array}$ \\
\hline $\begin{array}{l}\text { Nitrite } \\
\text { Nitrate } \\
\text { Chromium VI } \\
\text { Fluoride } \\
\text { Sodium Ion } \\
\text { Nickel } \\
\text { Iron } \\
\text { Sulfate } \\
\text { Cyanide Ion } \\
\text { Silver } \\
\text { Chloride } \\
\text { Cumulative Risk }\end{array}$ & $\begin{array}{l}1.10 E+04 \\
4.90 E+02 \\
4.10 E+02 \\
2.80 E+02 \\
2.90 E+01 \\
4.40 E-01 \\
1.40 E-01 \\
5.20 E-01 \\
1.40 E-03 \\
2.50 E-06 \\
5.10 E-08 \\
1.22 E+04\end{array}$ & $\begin{array}{c}90.09 \\
4.01 \\
3.36 \\
2.29 \\
2.38 \mathrm{E}-01 \\
3.60 \mathrm{E}-03 \\
1.15 \mathrm{E}-03 \\
4.26 \mathrm{E}-03 \\
1.15 \mathrm{E}-05 \\
2.05 \mathrm{E}-08 \\
4.18 \mathrm{E}-10 \\
100.00\end{array}$ & $\begin{array}{r}90.09 \\
94.10 \\
97.46 \\
99.75 \\
99.99 \\
99.99 \\
100.00 \\
100.00 \\
100.00 \\
100.00 \\
100.00\end{array}$ \\
\hline EDTA & $3.80 E+04$ & included & Imulative \\
\hline
\end{tabular}

Carcinogenic Analytes

\begin{tabular}{|c|c|c|c|c|}
\hline $\begin{array}{c}\text { Constituent } \\
\text { Name }\end{array}$ & $\begin{array}{r}\text { Risk } \\
\text { Index } \\
\end{array}$ & & $\begin{array}{l}\% \text { Total } \\
\text { Risk } \\
\end{array}$ & $\begin{array}{c}\text { Cumulative } \\
\% \text { Risk } \\
\end{array}$ \\
\hline $\begin{array}{l}99 \mathrm{Ic} \\
129 \mathrm{I} \\
14 \mathrm{C} \\
93 \mathrm{~m}_{\mathrm{Nb}} \\
242 \mathrm{~m}_{\mathrm{Am}} \\
238 \mathrm{Pu} \\
240 \mathrm{Pu} \\
239 \mathrm{Pu} \\
237 \mathrm{Pu} \\
241_{\mathrm{Am}} \\
242 \mathrm{Am} \\
241 \mathrm{Pu} \\
244 \mathrm{Cu} \\
\text { Cumulative Risk }\end{array}$ & $\begin{array}{l}1.6 \mathrm{E}+00 \\
1.1 \mathrm{E}-01 \\
9.0 \mathrm{E}-02 \\
1.9 \mathrm{E}-04 \\
1.7 \mathrm{E}-04 \\
9.7 \mathrm{E}-05 \\
5.5 \mathrm{E}-05 \\
3.9 \mathrm{E}-05 \\
3.8 \mathrm{E}-05 \\
4.2 \mathrm{E}-06 \\
3.0 \mathrm{E}-06 \\
1.2 \mathrm{E}-07 \\
1.3 \mathrm{E}-09 \\
1.8 \mathrm{E}+00\end{array}$ & & $\begin{array}{l}88.86 \\
6.11 \\
5.00 \\
1.06 \mathrm{E}-02 \\
9.44 \mathrm{E}-03 \\
5.39 \mathrm{E}-03 \\
3.05 \mathrm{E}-03 \\
2.17 \mathrm{E}-03 \\
2.11 \mathrm{E}-03 \\
2.33 \mathrm{E}-04 \\
1.67 \mathrm{E}-04 \\
6.66 \mathrm{E}-06 \\
7.22 \mathrm{E}-08 \\
100.00\end{array}$ & $\begin{array}{r}88.86 \\
94.97 \\
99.97 \\
99.98 \\
99.99 \\
99.99 \\
100.00 \\
100.00 \\
100.00 \\
100.00 \\
100.00 \\
100.00 \\
100.00\end{array}$ \\
\hline $\begin{array}{l}238 \mathrm{U} \\
235 \mathrm{U} \\
234 \mathrm{U} \\
233 \mathrm{U}\end{array}$ & $\begin{array}{l}5.1 \mathrm{E}+00 \\
1.8 \mathrm{E}-01 \\
1.2 \mathrm{E}-03 \\
2.5 \mathrm{E}-05\end{array}$ & $\begin{array}{l}\text { (not } \\
\text { (not } \\
\text { (not } \\
\text { (not }\end{array}$ & $\begin{array}{l}\text { included in } \\
\text { included in } \\
\text { included in } \\
\text { included in }\end{array}$ & $\begin{array}{l}\text { umulative risk } \\
\text { umulative risk) } \\
\text { umulative risk } \\
\text { umulative risk) }\end{array}$ \\
\hline
\end{tabular}


risk (i.e., high risk). The large uncertainties associated with EDTA and the uranium isotopes caused them to be ranked high, but these risk indexes were not included in the cumulative risk index, providing further conservation in selecting important analytes.

\section{A. 1 REFERENCES}

Buh1, T. E., and W. R. Hansen. 1984. Estimating the Risks of Cancer Mortality and Generic Defects Resulting from Exposures to Low Levels of Ionizing Radiation. LA-9893-MS, Los Alamos National Laboratory, Los Alamos, New Mexico.

Droppo, J. G., G. Whelan, J. W. Buck, D. L. Strenge, B. L. Hoopes, M. B. Walter, R. L. Knight, and S. M. Brown. 1989. Supplemental Mathematical Formulations: The Multimedia Environmental Pollutant Assessment System (MEPAS). PNL-7201, Pacific Northwest Laboratory, Richland, Washington.

NAS. 1990. Health Effects of Exposure to Low Levels of Ionizing Radiation: BEIR V. National Academy of Sciences Committee on the Effects of Ionizing Radiations, National Research Council, Washington, D.C.

Sewart, G. H., W. T. Farris, D. G. Huizenga, A. H. McMakin, G. P. Streile, and R. L. Treat. 1987. Long-Term Performance Assessment of Grouted Phosphate/ Sulfate Waste From $N$ Reactor Operations. PNL-6152, Pacific Northwest Laboratory, Richland, Washington.

U.S. Environmental Protection Agency (EPA). 1989. Reference Dose (RfD): Description and Use in Health Risk Assessments. Appendix A to the Integrated Risk Information System (IRIS).

Whelan, G., D. L. Strenge, J. G. Droppo Jr., B. L. Steelman, and J. W. Buck. 1987. The Remedial Action Priority System (RAPS): Mathematical Formulations. PNL-6200, Pacific Northwe " Laboratory, Richland, Washington. 


\section{APPENDIX B}

RADIOACTIVE WASTE AND NIOSH TOXICITY CLASSIFICATION FOR SINGLE-SHELL TANK ANALYTE ANALYSIS 


\section{APPENDIX B}

\section{RADIOACTIVE WASTE AND NIOSH TOXICITY CLASSIFICATION FOR SINGLE-SHELL TANK ANALYTE ANALYSIS}

This analysis was concerned with radioactive waste classification. Table B.1 provides a reproduction of the long- and short-lived radionuclide waste classification for near-surface disposal from the U.S. NRC'S 10 CFR 61 document. The units of the radionuclide waste classifications have been converted to curies per gram $(\mathrm{Ci} / \mathrm{g})$ to match the values computed in this analysis. These waste classification tables for radicactive waste were used to define the Waste Classification (WC) method for ranking radionuclides and computed concentration threshold (CT) values for single- shell tank (SST) wastes.

For the waste classification of chemicals, Regulation WAC 173-303-084 of the Washington State Department of Ecology was used. Unfortunately, this regulation was not designed to apply to ionic species that consitute toxic analytes in the SSTs. To adapt this regulation to the prioritization of SST analy c a method of calculating toxicity equivalent concentration values was developed to classify SST analyte toxicity. This equivalent method is used to define National Institute of Occupational Safety and Health (NIOSH) toxicity values for each of the SST analyte; analyzed in the ranking study.

In a strict sense, the regulation can be applied if 1) equilibrium relationships between all the ionic species in solution can be established, i) the pairs of ionic species can be sorted out, and 3) their in'ividual concentration-forming compounds can be estimated. This procesa, however, would be complicated, time-consuming, and impractical. An alternative method to assist in prioritizing SST analytes is based on evaluating the possible combinations of the ionic species forming in the tanks to correspond to the typical case scenario. For this approach, the toxicity values indicated in the "Toxic Category Table" of the state of Washingtor regulation should be located from the published sources such as the NIOSH Registry, EPA's IRIS database, and 
MEPAS chemical database for all the possible compounds that can be obtained through the combinations of the ionic species.

able B.2 was derived using this approach and assigns the toxicity category for each ionic species found in the SST based on the most realistic compounds in the SST. This table provides toxicity values to simple ion combinations based on $\mathrm{LD}_{50}$ values, which are defined as the mean lethal dose of a chemical expected to cause death in $50 \%$ of the test animals. This table al so shows $\mathrm{LD}_{50}$ (using the worst exposure route) values for rats, unless otherwise noted, and references for the toxicity values.

Table B.2 provides an alternate means of calculating equivalent toxicity concentrations for the waste mixtures in the SST waste quickly and economically without sacrificing accuracy. Even if models are developed for establishing equilibrium relationships, uncertainty will still exist because of 1) the uncertainty associated with the models, 2) the unavailability of the equilibrium constants for all the ionic species found in the SSTs, and 3) the unavailability of the toxicity values for the compounds derived from the possible combinations of the ionic species. The reason for using an alternate equivalent toxicity concentration method is to assist in prioritizing SST analytes, not to propose a new equivalent toxicity concentration calculation for regulatory waste classification. 
TABLE B.1. Long- and Short-Lived Radionuclide Waste

Classification Concentration

Long-Lived Radionuclides

Concentration

Radionuclide Name

for Class C Waste in SST ${ }^{(a)}$

Carbon-14

Carbon-14 in activated metal

Nickel-59 in activated metal $(\mu \mathrm{Ci} / \mathrm{g})$

Niobium-94 in activated metal

Technetium-99

Iodine-129

Alpha emitting TRU with half-

lives greater than 5 years

Plutonium-241

Curium-242

4. $44 E+00$

$4.44 E+01$

$1.22 E+02$

$1.11 \mathrm{E}-01$

$1.67 E+00$

4. $44 \mathrm{E}-02$

$1.00 \mathrm{E}-01$

$3.50 \mathrm{E}+00$

2.00E+01

Short-Lived Radionuclides

Concentration

for Class A, B, or C Waste in SST

Radionuclide Name $(\mu \mathrm{Ci} / \mathrm{g})$

Class $A$ Class B Class C

Total of all radionuclides with half-life less than 5 years

Tritium-3

Cobalt-60

$3.89 E+02$

$2.22 E+01$

$3.89 \mathrm{E}+02$

Nickel-63

$1.94 E+00$

$1.94 \mathrm{E}+01$

Nickel-63 in activated metal

2. $22 \mathrm{E}-02$

Stront ium-90

$5.56 \mathrm{E}-01$

(a)

(a)

(a)

(a)

(a)

$3.89 E+01$

(a)

Cesium-137

$3.89 \mathrm{E}+02$

$3.89 E+02$

$8.33 E+01$

$3.89 E+03$

$2.44 E+01$

$3.89 E+03$

2. $56 E+03$

(a) No limits established for these radionuclides for $\mathrm{Class} B$ or $\mathrm{C}$ waste. 
TABLE B.2. Equivalent Toxicity Category for Analytes and Other Compounds

\begin{tabular}{|c|c|c|c|c|c|}
\hline $\begin{array}{l}\text { Analyte } \\
\text { Name } \\
\end{array}$ & $\begin{array}{c}R f D \\
(\mathrm{mg} / \mathrm{kg} / \text { day })\end{array}$ & Ref. & $\begin{array}{r}L_{5} \\
(\mathrm{mg} / \mathrm{kg})\end{array}$ & $\begin{array}{l}\text { Toxicity } \\
\text { Category }\end{array}$ & Reference Compoun \\
\hline Ag & $3.0 \times 10^{-3}$ & IRIS & 75 & $\mathrm{c}$ & $\mathrm{Ag} \mathrm{NO}$ \\
\hline $\begin{array}{l}\text { A) } \\
\text { As } \\
\text { Ba }\end{array}$ & $1.0 \times 10^{-3}$ & $\begin{array}{l}\text { HEAST } \\
\text { HELS }\end{array}$ & $\begin{array}{r}3654 \\
25\end{array}$ & ${ }_{B}^{D}$ & Al $\left(\mathrm{NO}_{3}^{3}\right)_{3}$ \\
\hline $\begin{array}{l}\mathrm{Ba} \\
\mathrm{Be}\end{array}$ & $5.1 \times 10^{-2}$ & EPA & 1275 & $c$ & $\mathrm{Ba}\left(\mathrm{NO}_{3}\right)_{2}$ \\
\hline & $\cdots$ & RELS & 22 & B & 列l \\
\hline $\mathrm{C}_{2}^{2} \mathrm{H}_{6} \mathrm{H}_{5} \mathrm{O}_{3}$ & $\cdots$ & $\cdots$ & $\cdots$ & $D_{0}$ & $\ldots^{3}$ \\
\hline 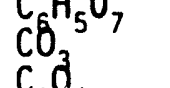 & $\cdots$ & RTECS & 2300 & D & $\mathrm{Na}_{2} \mathrm{CO}_{3}$ \\
\hline $\mathrm{Ca}^{2}$ & $\begin{array}{l}\cdots- \\
\cdots\end{array}$ & RTECS & 1000 & D & $\mathrm{CaCl}$ \\
\hline$c d$ & $\cdots$ & RTECS & 88 & D & $c d c]_{2}^{2}$ \\
\hline $\begin{array}{l}\text { Ce } \\
\text { Cl }\end{array}$ & $\cdots$ & $\begin{array}{l}\text { RTECS } \\
\text { DTEFC }\end{array}$ & 2111 & $D_{0}^{D}$ & $\mathrm{CeCl}_{3}^{6}$ \\
\hline $\begin{array}{l}\mathrm{Cr}^{+6} \\
\mathrm{Cu} \text { ions }\end{array}$ & $\begin{array}{l}5.0 \times 10^{-3} \\
5.0 \times 10^{-3}\end{array}$ & $\begin{array}{l}\text { EPA } \\
\text { HEAST }\end{array}$ & $\begin{array}{l}125 \\
125\end{array}$ & $\begin{array}{l}c \\
c\end{array}$ & $\begin{array}{l}\text { Chromic Acid } \\
\text { Cu(CN) }\end{array}$ \\
\hline EDTA & $6.0 \times 10^{-2}$ & $\begin{array}{l}\text { MEPAS } \\
\text { IRIS }\end{array}$ & $\begin{array}{l}397^{(a)} \\
1500\end{array}$ & $\begin{array}{l}D \\
D\end{array}$ & $\ldots$ \\
\hline $\mathrm{Fe}$ & 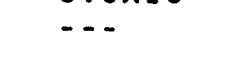 & RTECS & 428 & $\mathrm{c}$ & Ferrous Sulfate \\
\hline $\begin{array}{l}\text { Fe(CN) } \\
\text { HEDTA }\end{array}$ & $\cdots$ & RTECS & $\begin{array}{l}500(\mathrm{a}) \\
337\end{array}$ & c & -... \\
\hline $\mathrm{Hg}$ & c $12^{2}$ & MEPAS & 50 & $B$ & Mercuric Nitrate \\
\hline La & $5.1 \times 10^{2}$ & $\begin{array}{l}\text { MEPAS } \\
\text { RTECS }\end{array}$ & $\begin{array}{l}1.5 \times 10 \\
4184\end{array}$ & D & $\mathrm{LaCl}_{3}$ \\
\hline $\begin{array}{l}\text { Mn } \\
\text { No, }\end{array}$ & $2.2 \times 10^{-1}$ & EPA & 5500 & D & $\ldots^{3}$ \\
\hline $\mathrm{NO}_{3}^{2}$ & 1.0 & IRIS & 25000 & D & $\cdots$ \\
\hline $\begin{array}{l}\mathrm{Na} \\
\mathrm{Ni}\end{array}$ & $\begin{array}{l}3.0 \times 10^{6} \\
2 \times 10^{-2}\end{array}$ & $\begin{array}{l}\text { MEPAS } \\
\text { IRIS }\end{array}$ & $\begin{array}{l}7.5 \times 10^{\circ} \\
500\end{array}$ & $\begin{array}{l}D \\
C\end{array}$ & $\overline{\mathrm{NiCl}}$, \\
\hline $\begin{array}{l}\mathrm{OH} \\
\mathrm{PO}\end{array}$ & & MEPAS & & $\begin{array}{c}c \\
0 \\
0\end{array}$ & $\mathrm{KOH}^{2}$ \\
\hline $\begin{array}{l}\mathrm{Pb}^{4} \\
\mathrm{Sb}\end{array}$ & $1.4 \times 10^{3}$ & RTECS & 3613 & $D$ & $\mathrm{~Pb}\left(\mathrm{NO}_{3}\right)_{2}$ \\
\hline $\mathrm{SeO}_{4}$ & & $\begin{array}{l}\text { MICLS } \\
\text { RTECS }\end{array}$ & 1.6 & A & $\mathrm{Na}_{3} \mathrm{Se}_{5}$ \\
\hline $\begin{array}{c}\mathrm{SiO}_{3}^{4} \\
\mathrm{Sn}^{4}\end{array}$ & $2 . \times 10^{-1}$ & MEPAS & 5000 & $D$ & $\ldots-24$ \\
\hline $\mathrm{SO}_{4}$ & $7.1 \times 10^{1}$ & $\begin{array}{l}\text { MEPAS } \\
\text { MEP }\end{array}$ & $1.8 \times 10^{5}$ & D & $\cdots$ \\
\hline$y$ & $7.0 \times 10^{-3}$ & HEA & $2<50$ & $\mathrm{U}$ & \\
\hline $\mathrm{NO}_{4}$ & $\cdots$ & 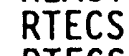 & 1190 & $D$ & $\mathrm{Na}_{2} \mathrm{WO}_{4}$ \\
\hline & & RTECS & 2290 & D & \\
\hline
\end{tabular}

(a) This was interpolated.

Indicates that was not computed or available.

RTECS Registry of toxic effects of chemical substances.

HEAST EPA's Health Effects Assessment Summary Tables. 


\section{B.1 REFERENCES}

10 CFR 61. 1982. U.S. Nuclear Regulatory Commission, "Land Disposal of Radioactive Waste." U.S. Code of Federat Regulations.

Ecology/EPA/DOE. 1989. Hanford Federal Facility Agreement and Consent Order. State of Washington Department of Ecology, No. 89-54, U.S. Environmental Protection Agency Docket No. 1089-03-04-120.

NIOSH. 1987. Registry of Toxic Effects of Chemical Substances: 1985-86 Edition. D. V. Sweet, ed. DHHS (NIOSH) Publication No. 87-114, National Institute of Occupational Safety and Health, U.S. Department of Health and Human Services, Washington, D.C.

U.S. Environmental Protection Agency (EPA). 1989. Reference Dose (RfD): Description and Use in Health Risk Assessments. Appendix A to the Integrated Risk Information System (IRIS).

Washington State. 1987. Washington State Dangerous Waste Regulations. WAC-173-303-084, 01ympia, Washington. 
APPÉNDIX C

RISK INDEX :ALCULATIONS FOR ANALYTES WITH DECAY PRODUCTS 
APPENDIX C

As discussed in Section 3.1.2, an (a) next to an analyte in Table 3.1 indicates that its risk index was computed from the risk from a daughter product. These daughter product risk indexes were not computed from the MEPAS code, but were estimated from the parent concentration and the decay chain over a 10,000-year period (time period of the groundwater model). The MEPAS groundwater model has a limitation so that the daughter products have the same chemical properties (solubility limit and adsorption coefficient $\left[K_{d}\right]$ ) as the parent analytes. The MEPAS code does compute decay of the parent and production of daughter decay chains.

As a result, parent analytes with high $K_{d} s$ (low mobility) and daughter products with low $K_{d} s$ (high mobility) do not reach the receptor with the 10,000-year time 1 imit of the groundwater model. An example of this is ${ }^{238} \mathrm{Pu}$ that has a half-life of 86 years and a $K_{d}$ of $10.0 \mathrm{~mL} / \mathrm{g}$ (retardation factor varies from 35.8 to 183.0 ). ${ }^{238} \mathrm{Pu}$ decays to ${ }^{234} \mathrm{U}$, which has a half-life of $2.47 \mathrm{E}+05$ years and a $K_{d}$ of $0.0 \mathrm{~mL} / \mathrm{g}$ (retardation factor of 1.0 or ${ }^{234} \mathrm{U}$ flows at the same speed as the groundwater).

To account for this, al1 the daughter analytes were run for the MEPAS groundwater model as parents (concentrations used from the TRAC database and their own solubilities and $K_{d} s$ ) and then a risk index was computed. Assuming that these risk indexes were not solubility-limited in the groundwater (i.e., the groundwater is saturated with the analyte and changes in concentration will not affect the risk index), the risk index is linear with the tank concentration. The original parent analyte concentrations from the TRAC database were decayed (multiple daughter products were considered) for a 10,000-year period. Ratios were then calculated for the resulting daughter concentration from the decay calculation to the daughter run as a parent concentration and its risk index. This produced a new risk index for the parent (e.g., $\left.{ }^{238} \mathrm{Pu}\right)$ from the daughter analyte $\left(\mathrm{e} . \mathrm{g} .,{ }^{234} \mathrm{U}\right)$. The result is a 
conservative but realistic estimate of the daughter analyte's risk index. Table C.I shows the parent-daughter product relationships and associated chemical properties. A modification to the MEPAS groundwater model is being considered to eliminate this limitation. 
TABLE C.1. Parent-Daughter Relationships and Chemical Properties

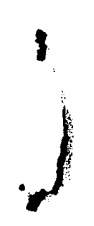

\section{Analyte Name}
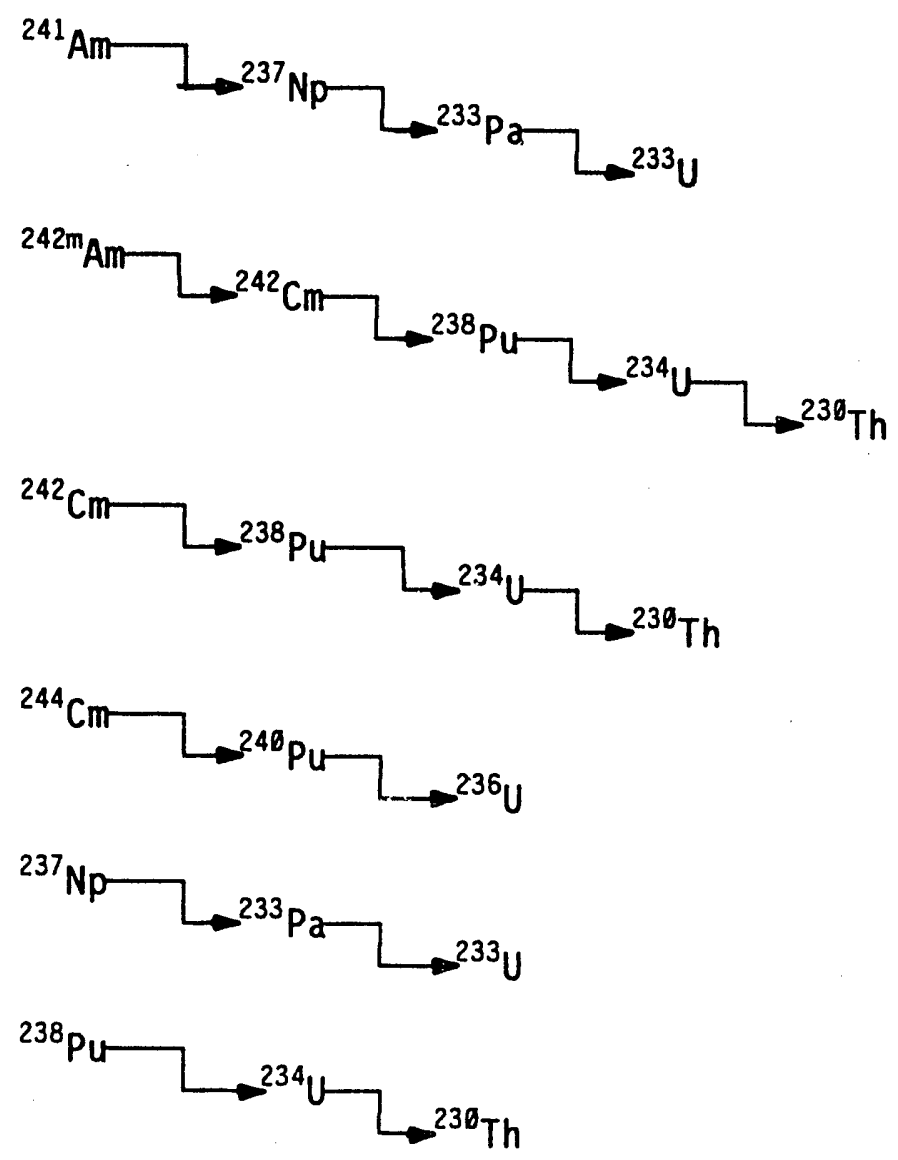

${ }^{239} \mathrm{Pu} \longrightarrow \longrightarrow{ }^{235} \mathrm{U}$
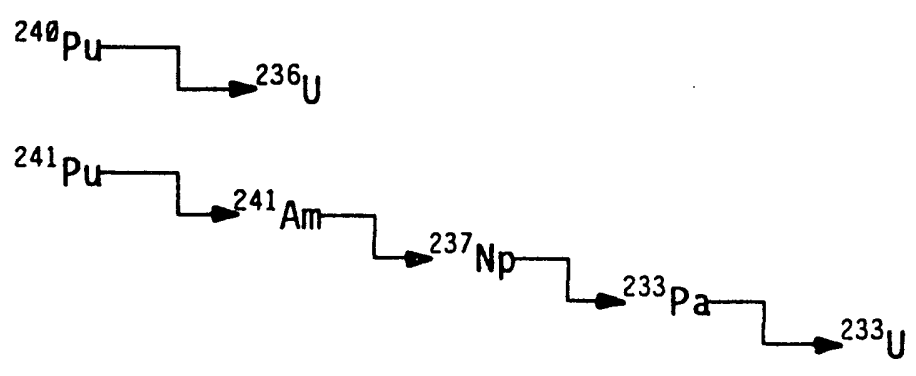

Chemical Properties

\begin{tabular}{cc}
$\begin{array}{c}\text { Half-Life } \\
\text { (years) }\end{array}$ & $\mathrm{K}_{\mathrm{d}}$ \\
\hline
\end{tabular}

$\begin{array}{rr}4.58 E+02 & 8.20 \\ 2.14 E+06 & 3.00 \\ 3.00 E-02 & 24.30 \\ 1.62 E+05 & 0.00\end{array}$

$1.52 E+02 \quad 8.20$

$4.5 \mathrm{E}-01 \quad 8.20$

$8.60 E+01 \quad 10.00$

$2.47 \mathrm{E}+05 \quad 0.00$

$8.00 E+04 \quad 40.00$

\section{$4.5 \mathrm{E}-01 \quad 8.20$}

8.60E+01 $\quad 10.00$

2.47E+05 $\quad 0.00$

8.00E+04 40.00

$1.76 E+01 \quad 8.20$

$6.58 \mathrm{E}+03 \quad 40.00$

2.36E+07 0.00

$2.14 E+06 \quad 3.00$

3.00E-02 24.30

$1.62 E+05 \quad 0.00$

$8.60 E+01 \quad 10.00$

2.47E+05 $\quad 0.00$

$8.00 E+04 \quad 40.00$

$2.44 E+04 \quad 40.00$

$7.10 \mathrm{E}+08 \quad 0.00$

$6.58 \mathrm{E}+03 \quad 40.00$

2.36E+07 0.00

$1.32 E+01 \quad 40.00$

$4.58 \mathrm{E}+02 \quad 8.20$

$2.14 E+06 \quad 3.00$

$3.00 \mathrm{E}-02 \quad 24.30$

$1.62 E+05 \quad 0.00$

C. 3 
8

1

APPENDIX D

COMPARISON OF CONCENTRATION THRESHOLD VALUES TO STANDARD HEALTH IMPACT LEVELS 
APPENDIX D

The concentration threshold (CT) concept is presented in this volume as an important indicator of the health impacts from single-shell tank (SST) analytes. The CT refers to the concentration below which an analyte concentration is considered insignificant in terms of human health impacts. The current analysis defines insignificant health impacts as 1 ess than $1 \%$ of the cumulative health impacts for a tank farm group. To estimate if $1 \%$ of the cumulative health impacts for a tank farm group is a reasonable criterion for determining the significance of SST analytes, this level is compared to standard health impact level.

There is some difficulty in defining acceptable risk for carcinogens because they are assumed to have no safe threshold; therefore, even a very low dose has some level of risk. The revised National Contingency Plan (40 CFR 300) identifies the range of acceptable risk as $10^{-4}$ to $10^{-6}$, based on individual lifetime cancer risks. For noncarcinogens, the chronic reference dose (RfD) is defined as an estimate of a daily exposure level for the human population that is likely to be without an appreciable risk of deleterious effects during a lifetime (EPA 1989). The acceptable risk of $10^{-4}$ and RfD for carcinogen and noncarcinogen, respectively, are used as standard health impact levels for this analysis.

The CT values computed for the SST analytes were compared to concentrations that represent the standard health impact levels defined above. The LTRR-CT values for Tank Farm Group B were used as input to the MEPAS model to compute peak groundwater concentrations at a hypothetical wel1 $5000 \mathrm{~m}$ downgradient from the tank farm group. The 5000-m distance was used to compare with the standard health impact level as per U.S. Environmental Protection Agency (EPA) standard 40 CFR 191. Table D.1 shows LTRR-CT values for Tank Farm Group $B$ analytes, the peak groundwater concentration corresponding to the CT values at a well $5000 \mathrm{~m}$ downgradient, the groundwater concentration at a 
TABLE D.1. Comparison of Concentration Threshold to Standard Risk Levels

\begin{tabular}{|c|c|c|c|c|}
\hline $\begin{array}{l}\text { Analyte } \\
\text { Name }\end{array}$ & $\begin{array}{l}\text { Tank Farm } \\
\text { Group B } \\
\text { LTRR-CT Value } \\
\text { (1R } / Q \text { Q }) \\
\end{array}$ & $\begin{array}{l}\text { Peak Groundwater } \\
\text { Concentration } \\
\text { Corresponding to } \\
\text { Cr Value at } 5000 \mathrm{~m} \\
(\mu \mathrm{g} / \mathrm{ml}) \\
\end{array}$ & $\begin{array}{l}\text { Groundwater } \\
\text { Concentration } \\
\text { Corresponding } \\
\text { to the RfD } \\
\text { (ug/m(s) } \\
\end{array}$ & $\begin{array}{c}\text { Ratio of Peak Groundwater } \\
\text { CT Value to Groundwater } \\
\text { Concentration Corresponding } \\
\text { to RfD Level } \\
\text { (dimensionless) } \\
\end{array}$ \\
\hline $\begin{array}{l}\mathrm{Be} \\
\mathrm{CN} \\
\mathrm{Cr}+6 \\
\mathrm{EDTR}^{+6} \\
\mathrm{~F} \\
\mathrm{Hg} \\
\mathrm{Na} \\
\mathrm{NO}_{2} \\
\mathrm{NO}_{3} \\
\mathrm{Sb}^{3} \\
\mathrm{SO}_{4}\end{array}$ & $\begin{array}{l}2.30 E+01 \\
5.82 E+00(a) \\
2.98 E+05(a) \\
7.45 E-01 \\
9.78 E+02 \\
2.44 E+01 \\
N 0 \mathrm{CT} \\
7.72 E+02 \\
2.12 E+04(a) \\
2.79 E+01 \\
\text { No CT } \\
7.61 E+02\end{array}$ & $\begin{array}{c}1.62 E-02 \\
1.34 E-03 \\
9.14 E-05 \\
8.70 E-04 \\
1.06 E+00 \\
1.16 E-03 \\
-16 \\
8.16 E-02 \\
3.37 E+01 \\
1.33 E-03 \\
\cdots-. \\
6.02 E-01\end{array}$ & $\begin{array}{c}1.47 E-02 \\
7.44 E-03 \\
3.81 E-04 \\
7.25 E-04 \\
9.64 E-01 \\
8.92 E-03 \\
\cdots-. \\
9.60 E-02 \\
2.81 E+01 \\
1.02 E-02 \\
\ldots .- \\
5.47 E-01\end{array}$ & $\begin{array}{c}1.10 E+00 \\
1.80 E-01 \\
2.40 E-01 \\
1.20 E+00 \\
1.10 E+00 \\
1.30 E-01 \\
-.- \\
8.50 E-01 \\
1.20 E+00 \\
1.30 E-01 \\
\cdots-. \\
1.10 E+00\end{array}$ \\
\hline
\end{tabular}

(a) Indicates that the $C T$ value for this analyte is based on its solubility limit.

... Indicates that wos not computed or available.

\begin{tabular}{|c|c|c|c|c|}
\hline $\begin{array}{l}\text { Analyte } \\
\text { Name }\end{array}$ & $\begin{array}{c}\text { Tank Farm } \\
\text { Group B } \\
\text { LTRR-CT Value } \\
\text { (ACi/S) } \\
\end{array}$ & $\begin{array}{l}\text { Concentration } \\
\text { Corresponding to } \\
\text { cr Value at } 5000 \mathrm{~m} \\
\text { (HCi/ml) } \\
\end{array}$ & $\begin{array}{l}\text { Groundwater } \\
\text { Concentration } \\
\text { Corresponding } \\
\text { to } 10^{-4} \mathrm{Risk} \\
\text { (uCi/ml) } \\
\end{array}$ & $\begin{array}{l}\text { Ratio of Peak Groundwater } \\
\text { CT Value to Groundwater } \\
\text { Concentrations that } \\
\text { Correspond to } 10^{-4} \text { Risk } \\
\text { (dimensionless) }\end{array}$ \\
\hline 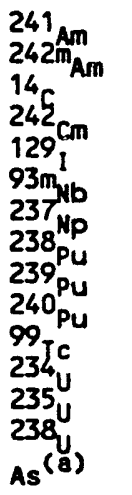 & $\begin{array}{l}1.55 E+02 \\
3.69 E-03 \\
6.12 E-03 \\
1.99 E-01 \\
2.08 E-05 \\
\text { No CT } \\
3.28 E-02 \\
7.54 E-01 \\
9.63 E+00 \\
1.43 E+00 \\
9.82 E-04 \\
\text { NO CT } \\
6.65 E-05 \\
4.67 E-05 \\
4.63 E+00\end{array}$ & $\begin{array}{c}1.15 E-08 \\
2.74 E-08 \\
2.91 E-05 \\
2.77 E-08 \\
9.48 E-08 \\
\cdots .- \\
1.15 E-08 \\
2.75 E-08 \\
2.79 E-08 \\
2.99 E-08 \\
5.90 E-05 \\
2.91 E-08 \\
2.91 E-08 \\
6.64 E-07 \\
1.94 E-03\end{array}$ & $\begin{array}{c}8.50 E-09 \\
2.04 E-08 \\
2.91 E-06 \\
2.05 E-08 \\
1.01 E-08 \\
-.- \\
8.55 E-09 \\
2.04 E-08 \\
2.06 E-08 \\
2.22 E-08 \\
4.92 E-07 \\
\cdots-. \\
2.08 E-08 \\
2.21 E-08 \\
1.39 E-03\end{array}$ & $\begin{array}{c}1.35 E+00 \\
1.34 E+00 \\
1.00 E+01 \\
1.35 E+00 \\
9.40 E+00 \\
\cdots . \\
1.35 E+00 \\
1.35 E+00 \\
1.35 E+00 \\
1.35 E+00 \\
1.20 E+02 \\
-\cdots \\
1.40 E+00 \\
3.00 E+01 \\
1.39 E+00\end{array}$ \\
\hline
\end{tabular}

(a) Indicates that the As values are in $\mu \mathrm{g} / \mathrm{g}$ and $\mu \mathrm{g} / \mathrm{ml}$. 
well that represents the standard health impact levels, and the ratio of the peak groundwater $\mathrm{CT}$ value to a groundwater concentration that represents the standard health impact level.

The ratio of the $\mathrm{CT}$ value and tank concentration that represents the standard health impact level at a we $115000 \mathrm{~m}$ downgradient indicates that for noncarcinogens, the CT vai es (based on $1 \%$ of cumulative health impact from the tank farm group) approximate the RfD value closely. For carcinogens, the CT values were within an order-of-magnitude of the tank concentrations that represent $10^{-4}$ risk, with the exception of ${ }^{99} \mathrm{Tc}$, which has a CT value two orders-of-magnitude above the $10^{-4}$ level.

The uncertainty associated with the computed CT values is at least plus or minus one order-of-magnitude. The CT values were computed for a tank farm group and not an individual SST (for an individual tank the CT value would be about one order-of-magnitude less than for a tank farm group), making the CT values conservative. This suggests that the $C T$ values are at least at the RfD concentration for noncarcinogens and are within an order-of-magnitude of the $10^{-4}$ health impact level for carcinogens. It is suggested that better physical properties for transuranics ( $K_{d}$ and solubility values) be obtained and the transport modeling be modified to better represent decay product risks. With the uncertainty and conservative nature of the CT calculation, the CT values computed for SST analytes compare well with standard health impact level concentrations.

\section{D.1 REFERENCES}

40 CFR 191. 1985. U.S. Environmenta1 Protection Agency, "Environmental Standards for the Management and Disposal of Spent Nuclear Fuel, High-Level and Transuranic Radioactive Wastes; Final Rule." U.S. Code of Federal Regulations.

40 CFR 300. 1990. U.S. Environmental Protection Agency, "National $0 i 1$ and Hazardous Substances Pollution Contingency Plan (National Contingency Plan) Final Rule." U.S. Code of Federal Regulations.

U.S. Environmentai Protection Agency (EPA). 1989. Risk Assessment Guidance for Superfund, Volume 1. Human Health Evaluation Manual (Part A). Interim Final, EPA/540/1-89/002, Official Emergency and Remedial Response, U.S. Environmental Protection Agency, Washington, D.C. 


\section{APPENDIX E}

CONCENTRATION THRESHOLD LIMITS FOR LONG-TERM RELEASE RISK, SHORT-TERM INTRUDER RISK, AND WASTE CLASSIFICATION

RANKING METHODS BY TANK FARM GROUPS 
TABLE E.1. Long-Term Release Risk Ranking Scenario Concentration Thresholds (CTs) for Carcinogenic Analytes

\begin{tabular}{|c|c|c|c|c|c|c|}
\hline \multirow[b]{2}{*}{$\begin{array}{l}\text { Ana lyte } \\
\text { Name } \\
\end{array}$} & \multicolumn{6}{|c|}{ CTs for Tank Farms } \\
\hline & $\begin{array}{l}\text { Group A } \\
(\mu C i / g)\end{array}$ & $\begin{array}{l}\text { Group } 8 \\
(\mu C i / a)\end{array}$ & $\begin{array}{l}\text { Group C } \\
\text { (le } i / g)\end{array}$ & $\begin{array}{l}\text { Group } S \\
(\mu C \mathrm{i} / \mathrm{gl}\end{array}$ & $\begin{array}{l}\text { Group } T \\
(\mu c i / a)\end{array}$ & $\begin{array}{l}\text { Group U } \\
(\mu c i / g)\end{array}$ \\
\hline $225 \mathrm{Ac}$ & -- & $\cdots$ & $\cdots$ & --- & --- & -- \\
\hline${ }^{227} \mathrm{Ac}$ & --- & --- &.-- & --- & -.- & --- \\
\hline $242 \mathrm{Am}$ & $1.75 E+91$ & $1.55 E+82$ & $6.07 E+01$ & $1.93 E+02$ & $2.61 E+62$ & $6.69 E+61$ \\
\hline $\begin{array}{l}242 \mathrm{Am} \\
242 \mathrm{~m}\end{array}$ & -- & --- & -.- & --- & --- & --- \\
\hline $243 \mathrm{Am}$ & $4.16 E+82$ & $3.69 E-83$ & $1.46 \mathrm{E}-83$ & $4.56 E-63$ & $6.64 E-63$ & $1.59 \mathrm{E}-63$ \\
\hline & --- & $\overline{---}$ & $\cdots$ & -- & --- & \\
\hline$A s^{(0)}$ & $6.72 E-91$ & $4.63 E+00$ & $1.16 E+60$ & $1.47 E+60$ & $1.33 E+66$ & $1.69 E-81$ \\
\hline $24 c^{\circ}$ & $4.29 \mathrm{E}-63$ & $6.12 \mathrm{E}-83$ & $3.56 E-63$ & $1.24 E-63$ & $2.25 \varepsilon-93$ & $6.25 E-64$ \\
\hline $24<\mathrm{Cm}$ & $2.17 E-62$ & $1.99 E-91$ & $7.41 E-82$ & $2.37 E-61$ & $3.24 E-91$ & $8.34 \mathrm{E}-92$ \\
\hline $245 \mathrm{Cm}$ & $6.13 E+61$ & $5.38 E+62$ & $2.69 E+82$ & $6.74 E+62$ & $9.33 E+82$ & $2.38 E+\emptyset 2$ \\
\hline $\begin{array}{l}{ }^{243} \mathrm{Cm} \\
135\end{array}$ & --- & -- & --- & --- & --- & --- \\
\hline $137 \mathrm{Cs}$ & $\cdots$ & -- & --- & $\cdots$ & $\cdots$ & $\cdots$ \\
\hline $60 \mathrm{co}$ & -- & -- & - & - & - & -- \\
\hline 30 & --- & -- & -- & -.- & --- & -.. \\
\hline 931 & $3.71 E-86$ & $2.08 E-85$ & $1.12 E-85$ & $4.17 E-66$ & $7.76 E-66$ & $2.14 E-66$ \\
\hline $94 \mathrm{Nb}$ & $\cdots$ & -- & --- & --- & --- & --- \\
\hline $59^{N i}$ & $\cdots$ & --. & $\cdots$ & $\cdots$ & $\cdots$ & --- \\
\hline $63_{\mathrm{Ni}}^{3 \mathrm{i}}$ &.- & -- & -.- & - & - & -- \\
\hline${ }^{237} \mathrm{~Np}$ & $3.69 \mathrm{E}-63$ & $3.28 \mathrm{E}-62$ & $1.27 E-62$ & $4.07 E-62$ & $5.61 E-62$ & $1.42 \mathrm{E}-62$ \\
\hline $\begin{array}{ll}201 \\
233\end{array}$ & -.- & --- & --- & -- & --- & --- \\
\hline $21 \theta_{\mathrm{pa}}$ & $\cdots$ & -- & $\cdots$ & --- & $\cdots$ & --- \\
\hline $21 \theta_{P o}^{P o}$ & -- & -- & $\cdots$ & $-\cdots$ & $-\cdots$ & -- \\
\hline${ }^{238} \mathrm{Pu}$ & $8.41 E-82$ & $7.54 E-61$ & $2.96 E-61$ & $9.25 E-01$ & $1.27 E+6 \theta$ & $3.21 \mathrm{E}-61$ \\
\hline${ }^{239} \mathrm{Pu}$ & $1.88 E+60$ & $9.63 E+60$ & $3.75 E+86$ & $1.18 E+61$ & $1.61 E+01$ & $4.26 \mathrm{E}+00$ \\
\hline${ }^{246} \mathrm{Pu}$ & $1.60 E-61$ & $1.43 E+6 \theta$ & $5.43 E-61$ & $1.78 E+00$ & $2.44 E+6 \theta$ & $6.07 E-01$ \\
\hline${ }^{241} \mathrm{Pu}$ & $5.93 E+62$ & $5.32 E+83$ & $2.88 E+03$ & $6.61 E+03$ & $8.94 E+63$ & $2.21 E+83$ \\
\hline${ }_{223}^{242} \mathrm{Pu}$ & --- & --- & --- & --- & --- & --- \\
\hline $225^{R a}$ & $\cdots$ & --- & -- & $\cdots$ & --- & -- \\
\hline $226_{\mathrm{Ra}}^{\mathrm{Ra}}$ & $\cdots$ & -- & $\cdots$ & $\cdots$ & -- & $\cdots$ \\
\hline $106_{\mathrm{Ru}}^{\mathrm{Ka}}$ & -- & -- & -- & --- & $-\cdots$ & $\cdots$ \\
\hline${ }^{79} \mathrm{Se}$ & -.. & --- & - & - & $\cdots$ & -- \\
\hline${ }^{151} \mathrm{Sm}$ & -- & -- & -- & --- & ... & --- \\
\hline $90 \mathrm{Sr}$ & --- & --- & -- & -- & ..- &.-- \\
\hline $\begin{array}{l}{ }^{99} \mathrm{Jc} \\
229 \mathrm{c}\end{array}$ & $1.65 \mathrm{E}-64$ & $9.82 E-64$ & $6.61 E-64$ & $2.09 E-\varnothing 4$ & $3.62 E-94$ & $1.36 \mathrm{E}-64$ \\
\hline $23 \theta^{\top}{ }^{20}$ & -.- & --- & --- & -.. & --- & --- \\
\hline $232^{\text {Th }}$ & $\cdots$ & $\cdots$ & $\cdots$ & $\cdots$ & $\cdots$ & $\cdots$ \\
\hline${ }^{234} \mathrm{Th}$ & $\cdots$ & $\cdots$ & -- & --- & --- & $\cdots$ \\
\hline $233 u$ & -.. & $\ldots$ & -- & $\cdots$ & $\cdots$ & -- \\
\hline${ }^{234} \mathrm{U}$ & $\cdots$ & --. & -.. & $\ldots$ & -.- & -.. \\
\hline${ }_{235}^{235} \mathrm{U}$ & $7.22 E-66$ & $6.65 E-85$ & $2.37 E-65$ & & $1.63 E-65$ & $4.44 E-66$ \\
\hline${ }^{236} u$ & $2.64 E-66$ & $4.32 E-05$ & $2.37 E-65$ & $3.67 E-65$ & $1.57 E-65$ & $4.49 E-66$ \\
\hline${ }^{238} \mathrm{U}$ & $6.83 E-96$ & $4.67 E-65$ & $3.81 E-65$ & $8.92 \mathrm{E}-06$ & $1.68 E-65$ & $1.83 \mathrm{E}-05$ \\
\hline $90_{Y}$ & --- & -- & --- & --- & --- & -.- \\
\hline${ }^{93} \mathrm{Zr}$ & --- & --- & --- & --- & --- & -.- \\
\hline
\end{tabular}

(a) Arsenic $1 \%$ concentration thresholds are in $(\mu \mathrm{g} / \mathrm{g})$. -.- Indicates that was not computed or available. 
TABLE E.2. Long-Term Release Risk Concentrations Thresholds (CTs) for Noncarcinogenic Analytes

\begin{tabular}{|c|c|c|c|c|c|c|}
\hline \multirow[b]{2}{*}{$\begin{array}{l}\text { Ana lyte } \\
\text { Name } \\
\end{array}$} & \multicolumn{6}{|c|}{ CTs for Tank Farms } \\
\hline & $\begin{array}{r}\text { Group A } \\
(\mu \mathrm{kg} / \mathrm{a})^{-}\end{array}$ & $\begin{array}{c}\text { Group } B \\
\left(\mu \mathrm{kg} / \mathrm{a} L^{2}\right.\end{array}$ & $\begin{array}{l}\text { Group C } \\
(\mu \mathrm{g} / \mathrm{g})\end{array}$ & $\begin{array}{c}\text { Group } S \\
(\mu \mathrm{g} / \mathrm{q})\end{array}$ & $\begin{array}{l}\text { Group T } \\
\left(\mu_{g} / g\right)\end{array}$ & $\begin{array}{l}\text { Group } U \\
\left(\mu_{g} / q\right)\end{array}$ \\
\hline Ag & -- & --- & -- & -- & -- & $\cdots$ \\
\hline Al & --- & $\cdots$ & --- & --- & --- & -.- \\
\hline As & -- & --- & --- & -- & -- & -- \\
\hline $\mathrm{Ba}$ & --- & --- & --- & --- & --- & --- \\
\hline Be & $3.31 E-61$ & $2.39 E+81$ & $1.77 E+68$ & $7.63 E+60$ & $6.61 E-81$ & $5.83 E-61$ \\
\hline$B i$ & --- & --- & --- & --- & --- & --- \\
\hline $\mathrm{C}_{2} \mathrm{O}_{4}$ & -- & -- & -- & -- & --- & --- \\
\hline $\mathrm{C}_{2}^{2} \mathrm{H}_{3} \mathrm{O}_{3}$ & -- & -- & -- & -- & -- & -- \\
\hline $\mathrm{C}_{6} \mathrm{H}_{5} \mathrm{O}_{7}$ & -- & $\cdots$ & -- & -- & -- & $\cdots$ \\
\hline $\mathrm{Ca}$ & -- & -- & -- & -- & --- & $\cdots$ \\
\hline$c d$ & -- & -- & -- & -- & -- & --- \\
\hline $\mathrm{Ce}$ & --- & $\cdots$ & --- & --- & --. & --- \\
\hline C1 & $1.14 E+\varnothing 2$ & $1.87 E+64$ & $1.86 E+83$ & $8.27 E+62$ & $1.36 E+63$ & $3.16 E+\varnothing 2$ \\
\hline $\mathrm{CN}$ & $3.78 E-91$ & --- & -- & --- & --- & --- \\
\hline Co & --- & -- & -- & --- & --- & --- \\
\hline $\mathrm{CO}_{3}$ & -- & $\cdots$ & -- & -- & -- & -- \\
\hline $\mathrm{Cr}^{+6}$ & -- & $\cdots$ & -- & $8.38 E+62$ & $1.87 E+83$ & $4.85 E+62$ \\
\hline $\begin{array}{l}\text { Cu } \\
\text { EDTA }\end{array}$ & $8.81 E-9 ?$ & $75 E_{-01}^{---}$ & $2 . \overline{--}-\theta_{101}$ & a $57 F_{-a 1}^{--}$ & --- & a \\
\hline $\begin{array}{l}\text { EDTA } \\
\text { F }\end{array}$ & $\begin{array}{l}8.81 E-\theta 2 \\
1.13 E+\varnothing 2\end{array}$ & $\begin{array}{l}7.45 E-61 \\
9.78 E+02\end{array}$ & $\begin{array}{l}2.61 E-\theta 1 \\
1.97 E+\theta 2\end{array}$ & $\begin{array}{l}4.57 E-81 \\
5.86 E+\varnothing 2\end{array}$ & $\begin{array}{l}1.25 E+68 \\
1.36 E+63\end{array}$ & $\begin{array}{l}2.46 E-61 \\
1.37 E+82\end{array}$ \\
\hline $\begin{array}{l}\mathrm{Fe} \\
\mathrm{Fe}(\mathrm{CN})+6\end{array}$ & -- & -- & -- & -- & $=$ & 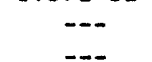 \\
\hline $\begin{array}{l}\text { HEDTA } \\
\text { HeAN }\end{array}$ & -- & -- & -- & --- &.-- & -- \\
\hline $\mathrm{Hg}$ & $1.82 E+90$ & $2.44 E+91$ & $1.39 \mathrm{E}+88$ & $4.48 E+80$ & $4.22 E+68$ & $7.78 E-61$ \\
\hline $\mathrm{NH}_{3}$ & --- & --- & --- & --- & --- & -.- \\
\hline La & --- & $-\cdots$ & $\cdots$ & $\cdots$ & $\overline{-\cdots}$ & $\cdots$ \\
\hline$M_{n}$ & --- & --. & --- & --- & --- & --- \\
\hline $\mathrm{Na}$ & --- & $-\cdots$ & --- & --- & --- & -- \\
\hline $\mathrm{Ni}$ & --- & --- & --- & --- & --- &.-- \\
\hline $\begin{array}{l}\mathrm{NO}_{2} \\
\mathrm{NO}_{2}\end{array}$ & $\begin{array}{l}7.28 E+\theta 1 \\
7 . \theta \theta E+\emptyset 2\end{array}$ & $\begin{array}{c}7.72 \mathrm{E}+62 \\
-\end{array}$ & $\begin{array}{l}4.26 E+\theta \theta \\
9.48 E+\theta 1\end{array}$ & $\begin{array}{l}7.37 E+\theta 1 \\
6.97 E+\varnothing 2\end{array}$ & $\begin{array}{l}1.69 E+62 \\
9.59 E+62\end{array}$ & $\begin{array}{l}2.55 E+\theta 1 \\
2.64 E+92\end{array}$ \\
\hline $\mathrm{OH}^{3}$ & $\begin{array}{c}1.08 E+62 \\
---\end{array}$ & -- & $\begin{array}{c}9.46 t+61 \\
\ldots-\end{array}$ & $\begin{array}{c}0.6 / t+62 \\
-.-\end{array}$ & $\begin{array}{c}9.59 t+62 \\
\ldots-\end{array}$ & $\begin{array}{c}2.64 E+82 \\
-.-\end{array}$ \\
\hline $\mathrm{Pb}$ & --- & --- & -- & -- & $\cdots$ & --- \\
\hline $\mathrm{PO}_{4}$ & -- & $\cdots$ & $\cdots$ & 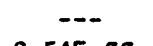 & $\cdots$ & --- \\
\hline $\mathrm{Sb}^{4}$ & $2.38 E+\theta \theta$ & $2.79 E+61$ & $1.52 E+60$ & $6.54 E+60$ & $8.62 E+6 \theta$ & $8.96 \mathrm{E}-91$ \\
\hline $\mathrm{SeO}_{4}$ & --- & --- & -- & $\cdots$ & -- & -- \\
\hline $\mathrm{SiO}_{3}$ & -- & $-\cdots$ & $\cdots$ & $\cdots$ & $\cdots$ & $\cdots$ \\
\hline so & --. & -.. & -.. & -.. & --- & $\ldots$ \\
\hline $\mathrm{Sr}^{4}$ & ...- & --- & --- & --. & -- & -.- \\
\hline $\mathrm{T} 1$ & ...- & --- & --- & --. & --- & --. \\
\hline$u$ & --- & --- & --- & $\cdots$ & --- & --- \\
\hline $\mathrm{wO}_{4}$ & --- & -- & --- & --- & -.- & -.- \\
\hline$v^{4}$ & $1.36 E+82$ & $7.61 E+62$ & $6.44 E+01$ & $2.81 E+\varnothing 2$ & $2.59 E+62$ & $4.85 E+61$ \\
\hline $2 n$ & --- & -- & --- & --- & --- & -.. \\
\hline $\mathrm{Zr}$ & $\cdots$ & $\cdots$ & $\cdots$ & -- & $\cdots$ & --- \\
\hline
\end{tabular}

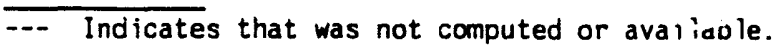


TABLE E.3. Short-Term Intruder Risk Concentration Thresholds (CTS) for Inhalation of Chemicals

\begin{tabular}{|c|c|c|c|c|c|c|}
\hline \multirow{2}{*}{$\begin{array}{l}\text { Ana lyte } \\
\text { Name }\end{array}$} & \multicolumn{6}{|c|}{ CTs for Tank Farms } \\
\hline & $\begin{array}{r}\text { Group } A \\
(\mu \mathrm{g} / \mathrm{q}) \\
\end{array}$ & $\begin{array}{r}\text { Group B } \\
(\mu \mathrm{g} / \mathrm{g}) \\
\end{array}$ & $\begin{array}{r}\text { Group C } \\
(\mu \mathrm{g} / \mathrm{g}) \\
\end{array}$ & $\begin{array}{r}\text { Group } S \\
(\mu \mathrm{g} / \mathrm{q}) \\
\end{array}$ & $\begin{array}{r}\text { Group } T \\
(\mu \mathrm{g} / \mathrm{g}) \\
\end{array}$ & $\begin{array}{r}\text { Group U } \\
(\mu \mathrm{g} / \mathrm{q})\end{array}$ \\
\hline $\mathrm{Ag}$ & $1.86 \mathrm{E}+62$ & $2.69 E+03$ & $1.23 E+03$ & $7.51 E+02$ & ?. $\angle \angle E+03$ & $2.49 E+02$ \\
\hline Al & $8.66 E+61$ & $1.25 \mathrm{E}+03$ & $5.74 E+62$ & $3.50 E+92$ & $1.50 \mathrm{E}+63$ & $1.16 E+02$ \\
\hline As & --- & -- &.-- & --- & --- & -- \\
\hline Bd & $8.66 \mathrm{E}+00$ & $1.25 E+62$ & $5.74 E+01$ & $3.50 E+01$ & $1.50 E+62$ & $1.16 E+01$ \\
\hline $\mathrm{Be}$ & --- & --- & --- & $-\cdots$ & --- & -- \\
\hline $\mathrm{Bi}$ & $5.45 \mathrm{E}+01$ & $7.88 \mathrm{E}+92$ & $3.61 \mathrm{E}+02$ & $2.20 E+\theta 2$ & $9.45 E+62$ & $7.29 E+\theta 1$ \\
\hline $\mathrm{C}_{2} \mathrm{O}_{4}$ & $4.46 E+62$ & $6.45 E+83$ & $2.9 .5 E+63$ & $1.80 E+83$ & $7.73 E+83$ & $5.97 E+02$ \\
\hline $\mathrm{C}_{2} \mathrm{H}_{3}^{4} \mathrm{O}_{3}$ & -- & --- & --- & --- & --- & --- \\
\hline $\mathrm{C}_{6} \mathrm{H}_{5} \mathrm{O}_{7}$ & --- & --- & --- & --- & -- & --- \\
\hline $\mathrm{Ca}$ & $2.48 E+03$ & $3.58 E+04$ & $1.64 E+64$ & $1.00 E+04$ & $4.29 E+64$ & $3.31 E+63$ \\
\hline $\mathrm{Cd}$ & $2.89 E+01$ & $5.31 E+00$ & $5.35 E+60$ & $4.46 E+62$ & $1.97 E+01$ & $6.59 E+61$ \\
\hline $\mathrm{Ce}$ & $5.23 E+n$ & $7.57 E+94$ & $3.46 E+84$ & $2.11 E+94$ & $9.07 E+04$ & $7.00 E+03$ \\
\hline $\mathrm{Cl}$ & $2.18 E+02$ & $3.15 E+93$ & $9.44 E+63$ & $8.81 E+62$ & $3.78 E+93$ & $2.92 E+82$ \\
\hline $\mathrm{CN}$ & --- & --- & --- & -- & --- & $\cdots$ \\
\hline Co & $3.62 E+62$ & $6.79 E+03$ & $3.17 E+83$ & $2.11 E+03$ & $8.62 E+93$ & $6.59 E+02$ \\
\hline $\mathrm{CO}_{3}$ & $4.63 E+83$ & $6.79 E+64$ & $3.67 E+04$ & $1.87 E+64$ & $8.03 E+04$ & $6.20 E+03$ \\
\hline $\begin{array}{l}\mathrm{Cr}^{+6} \\
\mathrm{Cu}\end{array}$ & $\begin{array}{c}3.10 E+00 \\
--\end{array}$ & $\begin{array}{c}7.90 E-01 \\
-\end{array}$ & $\begin{array}{c}7.95 E-01 \\
-\end{array}$ & $0.64 \mathrm{E}+01$ & $2.92 E+00$ & $9.80 E+\theta 0$ \\
\hline EDTA & $8.94 E+01$ & $1.16 E+83$ & $5.33 E+62$ & $3.25 E+02$ & $1.40 E+03$ & $1.98 \mathrm{E}+92$ \\
\hline $\begin{array}{l}\mathrm{F} \\
\mathrm{Fe}\end{array}$ & $\begin{array}{l}3.71 E+03 \\
5.32 E+02\end{array}$ & $\begin{array}{l}5.38 E+14 \\
7.71 E+6 i\end{array}$ & $2.46 E+04$ & $1.50 E+04$ & $6.44 E+64$ & $4.97 \mathrm{E}+03$ \\
\hline $\mathrm{Fe}(\mathrm{Cn})_{6}$ & $1.24 E+83$ & $1.79 E+64$ & $\begin{array}{l}3.53 E+83 \\
8.20 E+83\end{array}$ & $\begin{array}{l}2.15 E+03 \\
5.90 E+03\end{array}$ & $\begin{array}{l}9.23 E+03 \\
2.15 E+04\end{array}$ & $\begin{array}{l}7.13 E+02 \\
1.66 E+03\end{array}$ \\
\hline $\begin{array}{l}\text { HEDTA } 6 \\
\mathrm{Hg}\end{array}$ & $\begin{array}{l}8.34 E+02 \\
3.16 E+00\end{array}$ & $\begin{array}{l}1.21 E+84 \\
4.57 E+81\end{array}$ & $\begin{array}{l}5.53 E+03 \\
2.09 E+01\end{array}$ & $\begin{array}{l}3.37 E+03 \\
1.28 E+01\end{array}$ & $\begin{array}{l}1.45 E+04 \\
5.48 E+01\end{array}$ & $\begin{array}{l}1.12 E+\emptyset 3 \\
4.23 E+\emptyset \emptyset\end{array}$ \\
\hline $\mathrm{NH}_{3}$ & $5.81 E+03$ & 1. $99 E+05$ & $5.08 E+04$ & $3.38 E+04$ & $1.29 E+05$ & $1.86 E+\theta_{4}$ \\
\hline$K^{J}$ & $3.16 E+07$ & 4. $57 \mathrm{E}+08$ & $2.69 E+08$ & $1.28 E+08$ & $5.48 E+98$ & $4.23 E+67$ \\
\hline La & $1.04 E+04$ & $1.50 E+05$ & $6.86 E+74$ & $4.19 E+04$ & $1.80 E+05$ & $1.39 E+84$ \\
\hline Mn & $1.86 \mathrm{E}+01$ & $2.69 E+02$ & 1.2uz+02 & $7.51 E+01$ & $3.22 E+62$ & $2.49 E+81$ \\
\hline $\mathrm{Na}$ & $1.86 E+07$ & $2.69 E+08$ & $1.23 E+08$ & $7.51 E+87$ & $3.22 E+08$ & $2.49 E+67$ \\
\hline $\mathrm{Ni}$ & $1.51 E+02$ & $3.86 \mathrm{E}+01$ & $3.88 E+01$ & $3.24 E+03$ & $1.43 E+82$ & $4.78 E+62$ \\
\hline $\mathrm{NO}_{2}$ & $2.10 E+02$ & $3.05 \mathrm{E}+63$ & $1.39 E+03$ & $3.51 E+92$ & $3.6 \mathrm{JE}+83$ & $2.82 E+62$ \\
\hline $\begin{array}{l}\mathrm{NO}_{3}^{2} \\
\mathrm{OH}^{2}\end{array}$ & $6.19 E+04$ & $8.96 \mathrm{E}+65$ & $4.10 \mathrm{E}+05$ & $2.50 E+\emptyset 5$ & 1. $37 E+66$ & $8.29 E+64$ \\
\hline $\begin{array}{l}\mathrm{OH}^{-} \\
\mathrm{Pb}\end{array}$ & $\begin{array}{l}9.63 \mathrm{E}+02 \\
2.66 \mathrm{E}+01\end{array}$ & $\begin{array}{l}1.31 E+84 \\
3.85 E+82\end{array}$ & $\begin{array}{l}5.99 E+63 \\
1.76 E+82\end{array}$ & $\begin{array}{l}3.65 \mathrm{E}+93 \\
1.68 \mathrm{E}+92\end{array}$ & $\begin{array}{l}1.57 E+84 \\
4.62 E+02\end{array}$ & $\begin{array}{l}1.21 E+83 \\
3.56 E+\$ 1\end{array}$ \\
\hline $\mathrm{PO}_{4}$ & $4.33 E+02$ & $6.27 E+83$ & $2.87 E+63$ & $1.75 E+93$ & $7.5 E E+03$ & $5.80 E+02$ \\
\hline $\mathrm{Sb}^{4}$ & $-\overline{--}$ & -- & --- & --- & -- & -- \\
\hline $\begin{array}{l}\mathrm{SeO}_{4} \\
\mathrm{SiO}_{3}\end{array}$ & $\begin{array}{l}3.96 E+00 \\
1.24 E+04\end{array}$ & $\begin{array}{l}5.73 E+01 \\
1.79 E+05\end{array}$ & $\begin{array}{l}2.62 E+01 \\
8.20 E+04\end{array}$ & $\begin{array}{l}1.60 E+01 \\
5.00 E+04\end{array}$ & $\begin{array}{l}6.87 E+01 \\
2.15 E+05\end{array}$ & $\begin{array}{l}5.30 E+60 \\
1.66 E+64\end{array}$ \\
\hline $\mathrm{Sn}^{3}$ & $8.66 E+82$ & $1.25 E+84$ & $5.74 \mathrm{E}+03$ & $3.50 E+03$ & $1.50 E+84$ & 1.16E+ 103 \\
\hline $\mathrm{SO}_{4}$ & $4.33 E+93$ & $6.27 E+4$ & $2.875+84$ & $1.75 E+04$ & $7.52 E+64$ & $5.80 E+93$ \\
\hline $\mathrm{Sr}^{4}$ & $1.05 E+04$ & $1.52 \mathrm{E}+85$ & $6.97 E+94$ & $4.25 E+84$ & $1.83 E+05$ & 1. $41 E+04$ \\
\hline$T 1$ & $1.79 E+01$ & $3.35 E+02$ & $1.56 E+02$ & $1.04 E+02$ & $3.96 \mathrm{E}+02$ & $3.26 E+81$ \\
\hline U & $6.26 \mathrm{E}+01$ & $1.17 E+63$ & $5.47 E+92$ & $3.64 E+02$ & $1.39 E+03$ & $1.14 E+02$ \\
\hline v & $\overline{--}$ & -- & -- & --- & --- & $\cdots$ \\
\hline$w_{4}$ & $\therefore 37 E+03$ & $1.07 E+05$ & $4.88 E+94$ & $2.98 E+04$ & $1.28 E+05$ & $9.87 E+93$ \\
\hline $\begin{array}{l}\mathrm{Zn} \\
\mathrm{Zr}\end{array}$ & $\begin{array}{l}4.92 E+84 \\
5.67 E+83\end{array}$ & $\begin{array}{l}9 \angle 2 E+65 \\
8.21 E+04\end{array}$ & 4.36E+65 & $2.86 E+05$ & $1.99 E+66$ & $8.95 E+94$ \\
\hline & o. & $8.21 E+84$ & $3.76 E+B 4$ & $\therefore 29 E+64$ & $9.84 E+64$ & $7.59 \mathrm{E}+83$ \\
\hline
\end{tabular}

--- Indicates that was not computed or available. 
TABLE E.4. Short-Term Release Risk Concentration Thresholds (CTs) for Ingestion of Chemicals

\begin{tabular}{|c|c|c|c|c|c|c|}
\hline \multirow[b]{2}{*}{$\begin{array}{l}\text { Ana lyte } \\
\text { Name }\end{array}$} & \multicolumn{6}{|c|}{ CTs for Tank Farms } \\
\hline & $\begin{array}{r}\text { Group A } \\
(\mu \mathrm{g} / \mathrm{g})\end{array}$ & $\begin{array}{r}\text { Group } 8 \\
(\mu \mathrm{g} / \mathrm{g}) \\
\end{array}$ & $\begin{array}{r}\text { Group C } \\
(\mu \mathrm{g} / \mathrm{g})\end{array}$ & $\begin{array}{r}\text { Group } S \\
\left(\mu_{\mathrm{q} / q} / \mathrm{g}\right)\end{array}$ & $\begin{array}{r}\text { Group T } \\
(\mu \mathrm{g} / \mathrm{g}) \\
\end{array}$ & $\begin{array}{r}\text { Group U } \\
(\mu \mathrm{g} / \mathrm{g})\end{array}$ \\
\hline $\begin{array}{l}\mathrm{Ag} \\
\text { AI }\end{array}$ & $\begin{array}{l}1.34 E+02 \\
6.26 E+01\end{array}$ & $\begin{array}{l}2.51 E+03 \\
1.17 E+63\end{array}$ & $\begin{array}{l}\text { 1. } 17 E+63 \\
5.48 E+62\end{array}$ & $\begin{array}{l}7.86 E+02 \\
3.64 E+62\end{array}$ & $\begin{array}{l}2.97 E+03 \\
1.39 E+03\end{array}$ & $\begin{array}{l}2.44 E+02 \\
1.14 E+02\end{array}$ \\
\hline As & -.- & -. & -.- & -.- & -- & - \\
\hline Ba & $2.28 \mathrm{E}+93$ & $4.27 E+04$ & 2. $60 E+04$ & $33 E+04$ & 5. $95 E+64$ & 4.15E+83 \\
\hline $\mathrm{Be}$ & 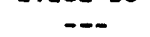 & -- & -.- & -. & -.. & -.. \\
\hline $8 i$ & $3.94 E+01$ & $7.38 E+92$ & $3.44 E+62$ & $2.29 E+02$ & $8.71 E+82$ & $7.16 E+01$. \\
\hline $\mathrm{C}_{2} \mathrm{O}_{4}$ & $3.22 E+\emptyset 2$ & $6.03 E+93$ & $2.82 E+03$ & $1.87 E+03$ & $7.13 E+03$ & $5.86 E+82$ \\
\hline $\mathrm{C}_{2}^{2} \mathrm{H}_{3}^{4} \mathrm{O}_{3}$ & $\ldots$ & - & $-\infty$ & -- & -- & $\ldots$ \\
\hline $\mathrm{C}_{6}^{2} \mathrm{H}_{5}^{3} \mathrm{O}_{7}^{5}$ & -- & --- & -- & --- & -- & -- \\
\hline$c_{a}^{6} 5$ & $1.79 E+83$ & $3.35 \mathrm{E},-24$ & $1.57 E+04$ & $1.04 E+64$ & $3.96 \mathrm{E}+94$ & $3.26 \mathrm{E}+83$ \\
\hline $\mathrm{cd}$ & $2.28 \mathrm{E}+01$ & $4.27 \mathrm{E}+02$ & $2.00 \mathrm{E}+02$ & 1.33E+92 & $5.95 E+02$ & $4.15 E+01$ \\
\hline $\mathrm{Ce}$ & $3.78 E+93$ & $7.68 E+04$ & $3.36 E+04$ & $2.19 E+04$ & $8.36 E+04$ & $6.87 E+03$ \\
\hline Cl & $1.57 E+62$ & $2.93 \hat{E}+83$ & 1. $38 E+63$ & $9.15 E+02$ & $3.49 E+63$ & 2.87E+82 \\
\hline $\mathrm{CN}$ & - & $\ldots$ & 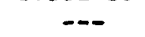 & -.- & -.. & -.. \\
\hline Co & $2.17 E+01$ & $3.14 E+Q 2$ & $1.44 E+62$ & $8.75 E+81$ & $3.75 E+62$ & $2.90 E+01$ \\
\hline $\mathrm{CO}_{3}$ & $3.34 E+\theta 3$ & $6.27 E+84$ & $2.93 E+04$ & $1.94 E+04$ & $7.41 E+64$ & $6.69 E+03$ \\
\hline $\mathrm{Cr}^{+6}$ & $2.24 E+12$ & $4.19 E+63$ & $1.96 \mathrm{E}+03$ & $1.3 \sigma E+\theta_{3}$ & $4.95 E+63$ & $4.07 E+02$ \\
\hline $\mathrm{Cu}$ & -.. & $\ldots$ & $\ldots$ & --- & -.- &.- \\
\hline EDTA & $5.81 E+01$ & 1.09E+93 & $5.09 E+62$ & $3.38 E+62$ & $1.29 E+63$ & $1.06 \mathrm{E}+02$ \\
\hline & $2.68 \mathrm{E}+03$ & $5.63 E+94$ & $2.35 E+84$ & $1.56 E+94$ & $5.94 E+84$ & $4.88 E+03$ \\
\hline $\mathrm{Fe}$ & $5.81 E+84$ & $1.69 E+96$ & 5. $69 E+65$ & $3.38 E+05$ & $1.29 E+86$ & $1.06 \mathrm{E}+95$ \\
\hline $\mathrm{Fe}(\mathrm{CN})_{6}$ & $1.68 E+04$ & $7.83 E+83$ & $5.20 E+63$ & $1.98 E+04$ & $1.63 E+03$ & \\
\hline HEDTA ${ }^{\circ}$ & $6.63 E+62$ & $1.13 E+04$ & $5.27 E+63$ & $3.56 E+03$ & 1. $33 E+84$ & $1.10 E+83$ \\
\hline $\mathrm{Hg}$ & $8.94 E+61$ & $1.68 E+03$ & $7.83 E+02$ & $5.2 \theta E+62$ & $1.98 E+63$ & $1.63 E+02$ \\
\hline $\mathrm{NH}_{3}$ & $8.05 E+03$ & $1.16 E+85$ & $5.33 E+04$ & $3.25 E+04$ & $1.39 E+05$ & 1.08E+04 \\
\hline$k^{3}$ & $2.28 E+07$ & $4.27 E+68$ & $2.00 E+08$ & $1.33 \mathrm{E}+08$ & $5.05 E+08$ & $4.15 E+67$ \\
\hline La & $7.48 E+03$ & $1.40 E+05$ & $6.55 E+04$ & $4.35 E+04$ & $1.66 E+95$ & $1.36 E+84$ \\
\hline$M n$ & $9.84 E+63$ & 1. $3 A \ddot{t}+65$ & 8. $61 E+04$ & $5.72 E+04$ & $2.18 E+65$ & $1.79 E+04$ \\
\hline $\mathrm{Na}$ & $1.34 E+07$ & $2.51 E+68$ & $1.17 E+68$ & $7.86 E+97$ & $2.97 E+68$ & $2.44 E+87$ \\
\hline$N i$ & $8.94 E+02$ & $1.68 E+84$ & $7.83 E+63$ & $5.2 \theta E+\theta 3$ & $1.98 E+64$ & $1.63 E+03$ \\
\hline $\mathrm{NO}_{2}$ & 1. $52 E+02$ & $2.85 E+83$ & $1.33 E+63$ & $8.84 E+92$ & $3.37 E+03$ & $2.77 E+02$ \\
\hline $\mathrm{NO}_{3}^{2}$ & $4.47 E+04$ & $8.38 E+05$ & $3.91 E+95$ & $2.60 E+95$ & $9.96 E+05$ & $8.14 E+64$ \\
\hline $\mathrm{OH}^{3}$ & $6.53 E+62$ & $1.22 E+04$ & $5.71 E+03$ & $3.79 E+83$ & $1.45 E+84$ & 1. $19 E+03$ \\
\hline $\mathrm{Pb}$ & $6.26 E+01$ & $1.17 E+63$ & $5.48 E+62$ & $3.64 E+92$ & 1. $39 E+63$ & 1.14E+82 \\
\hline $\mathrm{PO}_{\mathrm{A}}$ & $2.06 E+94$ & $3.86 E+05$ & $1.86 E+05$ & $1.20 E+05$ & $4.55 E+05$ & $3.74 E+04$ \\
\hline $\mathrm{SeO}_{4}^{4}$ & $2.66 E+\theta 0$ & 5.36E+01 & $2.50 E+\theta 1$ & $1.66 E+\theta 1$ & $6.34 E+01$ & $5.21 E+80$ \\
\hline $\mathrm{SiO}_{3}^{4}$ & $8.94 E+03$ & $1.68 E+05$ & $7.83 E+94$ & $5.20 E+84$ & $1.98 E+85$ & $1.63 E+04$ \\
\hline $\mathrm{Sn}^{3}$ & $4.47 E+02$ & $8.38 E+63$ & $3.91 E+03$ & $2.69 E+93$ & $9.98 E+03$ & $8.14 E+82$ \\
\hline $\mathrm{SO}_{4}$ & $3.17 E+96$ & $5.95 E+07$ & $2.78 E+67$ & $1.85 E+87$ & $7.03 E+67$ & $5.78 E+06$ \\
\hline $\mathrm{Sr}^{4}$ & $7.60 E+03$ & $1.42 E+65$ & $6.65 E+84$ & $4.42 E+84$ & $1.68 E+05$ & 1.38E+64 \\
\hline $\mathrm{TI}$ & $2.48 E+01$ & $3.58 \mathrm{E}+02$ & $1.64 E+02$ & 1. $. \theta \partial E+\theta 2$ & $4.28 E+02$ & $3.32 E+81$ \\
\hline$U$ & $8.67 E+01$ & $1.25 E+63$ & $5.47 E+02$ & $3.50 E+02$ & $1.50 E+03$ & $1.16 E+02$ \\
\hline$v$ & -- & -- & --- & -- & -- & $\ldots$ \\
\hline $\mathrm{wO}_{4}$ & $2.13 E+03$ & $3.99 E+04$ & $1.86 E+84$ & $1.24 E+04$ & $4.71 E+04$ & $3.87 E+83$ \\
\hline $2 n^{4}$ & $\begin{array}{l}2.17 E+63 \\
4.10 E+83\end{array}$ & $\begin{array}{l}3.14 E+04 \\
7.68 E+84\end{array}$ & $\begin{array}{l}1.44 E+94 \\
3.58 E+94\end{array}$ & $\begin{array}{l}8.75 E+03 \\
2.38 E+94\end{array}$ & $3.75 E+642$ & $2.90 \mathrm{E}+03$ \\
\hline & & & & $2.38 t+64$ & $9.07 t+64$ & $7.46 E+63$ \\
\hline
\end{tabular}

-- Indicates that was not computed or available. 
TABLE E.5. Concentration Thresholds (CTs) for Inhalation of Radionuclides

\begin{tabular}{|c|c|c|c|c|c|c|}
\hline \multirow{2}{*}{$\begin{array}{l}\text { Ana lyte } \\
\text { Name }\end{array}$} & \multicolumn{6}{|c|}{ CTs for Tank Farms } \\
\hline & $\begin{array}{l}\text { Group A } \\
(\mu \mathrm{C} i / g)\end{array}$ & $\begin{array}{l}\text { Group B } \\
(\text { (uc } \mathrm{i} / \mathrm{a})\end{array}$ & $\begin{array}{l}\text { Group C } \\
(\mu \mathrm{Ci} / \mathrm{g})\end{array}$ & $\begin{array}{l}\text { Group S } \\
(\mu \mathrm{C} i / g)\end{array}$ & $\begin{array}{l}\text { Group } T \\
(\mu \mathbb{C} i / q)\end{array}$ & $\begin{array}{l}\text { Group U } \\
(\mu C i / g)\end{array}$ \\
\hline $225 \mathrm{AC}$ & $4.13 E+00$ & $2.69 E-61$ & $7.28 \mathrm{E}-01$ & $2.74 E-61$ & $5.58 E-62$ & $4.08 E-02$ \\
\hline${ }^{227} \mathrm{AC}$ & --- & --- & --- & --- & $-\cdots$ & --- \\
\hline $241 \mathrm{Am}$ & $8.73 E-62$ & $4.43 E-63$ & $1.54 E-92$ & $5.80 E-03$ & $1.16 E-63$ & $8.63 E-64$ \\
\hline $242 \mathrm{Am}$ & $7.57 E+62$ & $3.84 E+01$ & $1.33 E+62$ & $5.03 E+01$ & $1.01 E+01$ & $7.48 E+60$ \\
\hline $242 m_{A m}$ & $8.96 E-62$ & $4.52 E-63$ & $1.57 E-82$ & $5.91 E-63$ & $1.19 E-63$ & $8.80 E-64$ \\
\hline & $8.73 E-82$ & $4.43 E-03$ & $1.54 E_{-}-62$ & $5.89 E-93$ & $1.16 E-03$ & $8.63 E-04$ \\
\hline & $2.16 E+04$ & $1.10 E+63$ & $3.81 E+83$ & $1.44 E+63$ & $2.88 E+62$ & 2.14E+62 \\
\hline & $2.52 E+\theta 0$ & $1.28 E-61$ & $4.45 E-01$ & $1.68 \mathrm{E}-01$ & 3. $36 E-02$ & $2.49 E-62$ \\
\hline${ }^{14} \mathrm{Cm}$ & $1.62 E-01$ & $8.23 E-63$ & $2.86 E-02$ & 1. $08 \mathrm{E}-02$ & $2.16 E-03$ & $1.60 E-63$ \\
\hline & $8.25 E-82$ & 4.19E-03 & $1.46 E-02$ & $5.48 E-03$ & $1.10 E-63$ & $8.16 E-84$ \\
\hline & - & --- & -- & -- & -- & -- \\
\hline${ }^{137} \mathrm{Cs}$ & $4.99 E+83$ & $2.53 E+62$ & $8.80 E+02$ & $3.31 \mathrm{E}+02$ & $6.65 E+01$ & $4.93 E+81$ \\
\hline${ }^{60} \mathrm{Co}$ & $2.06 E+82$ & 1.EJE+ & $3.64 E+81$ & $1.37 E+01$ & $2.75 E+00$ & $2.04 E+00$ \\
\hline${ }^{3} \mathrm{H}$ & $7.21 E+65$ & $3.65 E+04$ & $1.27 E+05$ & $4.79 E+04$ & $9.60 E+03$ & $7.13 t+03$ \\
\hline & $2.67 E+62$ & $1.36 E+01$ & $4.71 E+61$ & $1.77 E+01$ & $3.56 \mathrm{E}+00$ & $2.64 E+\theta 0$ \\
\hline & - & -- & -- & --- & $-\infty$ & $=-$ \\
\hline${ }^{94} \mathrm{Nb}$ & $1.01 E+02$ & $5.56 E+60$ & $1.93 E+01$ & $7.29 E+00$ & $1.46 \mathrm{E}+0 \theta$ & $1.08 E+00$ \\
\hline${ }_{63}^{59} \mathrm{Ni}$ & $1.68 E+04$ & $8.52 E+62$ & $2.97 E+83$ & 1. $12 E+03$ & $2.24 E+02$ & $1.66 E+02$ \\
\hline${ }^{63} \mathrm{Ni}$ & $7.21 E+03$ & $3.66 E+02$ & $1.27 E+03$ & $4.79 E+02$ & $9.61 E+91$ & $7.12 E+81$ \\
\hline $237 \mathrm{~Np}$ & $9.68 E-62$ & $4.61 E-63$ & $1.60 \mathrm{E}-02$ & $6.03 E-03$ & $1.21 E-93$ & $8.97 E-04$ \\
\hline${ }^{231} \mathrm{~Pa}$ & $\ldots$ & -- & -.- & --- & -.- & -- \\
\hline $233 \mathrm{~Pa}$ & $4.78 E+63$ & $2.42 E+02$ & $8.43 E+02$ & $3.17 E+02$ & $6.37 E+01$ & $4.72 E+91$ \\
\hline & --- & --- & $\ldots$ & -. & -- & -- \\
\hline & $4.83 E+00$ & $2.45 E-81$ & $8.52 E-61$ & $3.21 E-01$ & $6.44 E-92$ & $4.77 E-02$ \\
\hline${ }^{3} \mathrm{Pu}$ & $9.87 E-02$ & $5.01 E-03$ & $1.74 E-62$ & $6.55 E-03$ & $1.32 E-03$ & $9.75 E-04$ \\
\hline${ }^{239} \mathrm{Pu}$ & $8.73 E-22$ & $4.43 E-83$ & $1.54 E-02$ & $5.80 E-63$ & $1.16 \mathrm{E}-03$ & $8.63 E-04$ \\
\hline $24 \theta_{\mathrm{Pu}}$ & $8.73 E-02$ & $4.43 E-83$ & $1.54 E-82$ & $5.80 E-63$ & $1.16 E-03$ & $8.63 E-94$ \\
\hline & $4.54 E+60$ & $2.30 E-01$ & $8.01 E-01$ & $3.62 \mathrm{E}-61$ & $6.65 E-62$ & $4.49 E-82$ \\
\hline${ }_{3}^{12} \mathrm{Pu}$ & $1.01 E-01$ & $5.60 E-63$ & $1.95 E-02$ & $7.35 E-03$ & $1.47 E-01$ & $1.09 E-03$ \\
\hline${ }^{223} \mathrm{Ra}$ & $5.82 E+60$ & $2.95 E-61$ & $1.03 E+00$ & $3.87 E-01$ & $7.76 \mathrm{E}-02$ & $5.75 E-92$ \\
\hline${ }^{225} \mathrm{Ra}$ & $5.82 E+6 \theta$ & $2.95 E-01$ & $1.03 E+60$ & $3.87 E-01$ & $7.76 E-62$ & $5.75 E-02$ \\
\hline${ }^{226} \mathrm{Ra}$ & -- & $\ldots$ & --- & -- & -.- & --- \\
\hline $106_{\mathrm{Ru}}$ & $1.03 E+02$ & $5.24 E+\theta 0$ & $1.82 \mathrm{E}+01$ & $6.85 E+00$ & $1.38 E+\theta \theta$ & $1.02 E+00$ \\
\hline${ }_{151}^{79} \mathrm{Se}$ & --- & --- & $-\cdots$ & -- & --- & --- \\
\hline${ }_{156}^{151} \mathrm{Sm}$ & -. & $\ldots$ & --- & --- & -- & $\cdots$ \\
\hline${ }^{126} \mathrm{Sn}$ & $4.59 E-82$ & $2.32 E+01$ & 8. $69 E+01$ & $3.05 E+01$ & $6.11 E+00$ & $4.54 E+00$ \\
\hline${ }^{90} \mathrm{Sr}$ & $3.49 E+01$ & $1.77 E+00$ & $6.16 E+\theta 0$ & $2.32 E+\theta \theta$ & 4. $66 E-81$ & $3.45 E-81$ \\
\hline${ }^{99} \mathrm{Tc}$ & $5.47 E+03$ & $2.78 E+92$ & $9.65 E+62$ & $3.63 E+02$ & $7.29 E+01$ & $5.41 E+01$ \\
\hline${ }^{229} \mathrm{Th}$ & --- & --- & --- & --- & --- & -. \\
\hline${ }^{238}{ }^{T h}$ & $1.42 E-01$ & $7.20 E-03$ & $2.50 E-82$ & $9.42 E-03$ & $1.89 E-03$ & $1.40 E-03$ \\
\hline${ }^{232} \mathrm{Th}$ & $2.84 E-82$ & $1.44 E-83$ & $5.01 E-03$ & $1.89 E-63$ & $3.78 E-84$ & $2.81 E-04$ \\
\hline${ }^{234}$ Th & $1.30 E+93$ & $6.58 \mathrm{E}+01$ & $2.29 E+62$ & $8.61 E+\emptyset 1$ & 1. $73 \mathrm{E}+81$ & $1.28 E+01$ \\
\hline${ }^{233} \mathrm{U}$ & $3.49 \mathrm{E}-01$ & $1.77 \mathrm{E}-02$ & $6.16 E-02$ & $2.32 E-62$ & 4. $66 E-83$ & $3.45 \mathrm{E}-03$ \\
\hline $234 \mathrm{U}$ & $3.49 E-61$ & $1.77 \mathrm{E}-62$ & $6.16 E-82$ & $2.32 \mathrm{E}-02$ & $4.66 E-63$ & $3.45 E-03$ \\
\hline $235 \mathrm{U}$ & $3.78 \mathrm{E}-01$ & $1.92 \mathrm{E}-02$ & $6.67 E-02$ & $2.51 E-02$ & $5.04 E-03$ & $3.74 E-03$ \\
\hline $236 u$ & $3.49 E-81$ & $1.77 \mathrm{E}-02$ & $6.16 E-02$ & $2.32 E-82$ & 4. $65 E-63$ & $3.45 E-03$ \\
\hline $238 \mathrm{U}$ & $3.78 E-01$ & $1.92 E-02$ & $6.67 E-0 z$ & $2.51 E-02$ & $5.04 E-63$ & $3.74 E-03$ \\
\hline $9 \theta_{Y}$ & $5.46 E+63$ & $2.74 E+82$ & $9.53 E+02$ & $3.59 E+02$ & $7.20 E+81$ & $5.34 E+01$ \\
\hline${ }^{93} \mathrm{Zr}$ & $1.42 E+02$ & $7.19 E+00$ & $2.59 E+61$ & $9.44 E+\theta 0$ & $1.86 E+86$ & 1. $4 \theta E+\theta \theta$ \\
\hline
\end{tabular}

-- Indicates that was not computed or available. 
TABLE E.6. Concentration Thresholds (CTS) for Ingestion of Radionuclides

\begin{tabular}{|c|c|c|c|c|c|c|}
\hline \multirow[b]{2}{*}{$\begin{array}{l}\text { Ana lyte } \\
\text { Name } \\
\end{array}$} & \multicolumn{6}{|c|}{ CTs for Tank Farms } \\
\hline & $\begin{array}{l}\text { Group A } \\
(\mu \mathrm{Ci} / \mathrm{g})\end{array}$ & $\begin{array}{l}\text { Group B } \\
(\mu \mathrm{C} / \mathrm{g})\end{array}$ & $\begin{array}{l}\text { Group C } \\
(\mu \mathrm{C} j / \mathrm{g})\end{array}$ & $\begin{array}{l}\text { Group S } \\
(\underline{(L \mathrm{i} / \mathrm{g})}\end{array}$ & $\begin{array}{l}\text { Group T } \\
(\mu \mathrm{C} / \mathrm{g})\end{array}$ & $\begin{array}{l}\text { Group U } \\
(\mu \mathrm{C} i / g) \\
\end{array}$ \\
\hline & $3.98 E+01$ & $1.58 \mathrm{E}+00$ & $3.90 E+00$ & $2.31 E+00$ & $2.97 E-01$ & $3.26 E-01$ \\
\hline $227 \mathrm{AC}$ & -- & $\ldots$ & $\ldots$ &.- &.- & $\ldots$ \\
\hline & $9.72 E-61$ & $3.86 E-82$ & $9.54 E-02$ & $5.64 E-62$ & $7.26 E-03$ & $7.96 \mathrm{E}-93$ \\
\hline & $3.36 E+03$ & $1.34 E+02$ & $3.30 E+02$ & $1.95 E+62$ & $2.51 E+61$ & $2.76 E+01$ \\
\hline $242 m_{A m}$ & $2.08 E+60$ & $8.27 E-62$ & $2.04 E-81$ & $1.21 \mathrm{E}-01$ & $1.56 E-62$ & $1.71 E-02$ \\
\hline $243 \mathrm{Am}$ & $9.72 E-91$ & $3.86 E-62$ & $9.54 E-02$ & $5.64 E-62$ & $7.26 E-63$ & $7.96 E-93$ \\
\hline & $2.08 E+63$ & $8.27 E+01$ & $2.04 E+02$ & $1.21 E+02$ & $1.56 E+\emptyset 1$ & $1.71 E+01$ \\
\hline & $6.34 E+01$ & $2.52 E+60$ & $6.22 E+90$ & $3.68 E+00$ & $4.73 E-61$ & $5.19 E-81$ \\
\hline & $3.64 E+60$ & $1.45 E-01$ & $3.58 E-01$ & $2.12 E-61$ & $2.72 E-62$ & $2.99 E-02$ \\
\hline & $1.90 E+00$ & $7.55 E-82$ & $1.87 E-01$ & $1.10 \mathrm{E}-01$ & $1.42 E-02$ & $1.56 \mathrm{E}-82$ \\
\hline $137 \mathrm{Cs}$ & -- & --- & -- & -- & -- & -- \\
\hline${ }^{137} \mathrm{Cs}$ & $3.64 E+83$ & $1.45 E+82$ & $3.58 E+92$ & $2.12 E+02$ & $2.72 E+01$ & $2.99 E+81$ \\
\hline${ }^{60} \mathrm{Co}$ & $1.62 E+02$ & $6.44 E+00$ & $1.59 E+01$ & $9.41 E+00$ & $1.21 \mathrm{E}+00$ & $1.33 E+00$ \\
\hline & $6.94 E+94$ & $2.76 E+83$ & $6.81 E+83$ & $4.63 E+63$ & $5.19 E+02$ & $5.68 E+02$ \\
\hline 1291 & $1.56 E+01$ & $6.20 E-01$ & $1.53 E+00$ & $9.67 E-01$ & $1.17 E-01$ & $1.28 E-01$ \\
\hline $93 m_{\mathrm{Nb}}$ & --- & -. & ..- & -.- & -- & -- \\
\hline $94 \mathrm{Nb}$ & $6.12 E+02$ & $2.44 E+01$ & $6.01 E+01$ & $3.56 E+91$ & $4.58 \mathrm{E}+00$ & $5.01 E+\theta 0$ \\
\hline $59 \mathrm{Ni}$ & $2.68 E+94$ & $8.29 E+02$ & 2. $04 E+63$ & $1.21 E+03$ & $1.56 \mathrm{E}+02$ & $1.70 \mathrm{E}+02$ \\
\hline & $7.54 E+03$ & $2.99 E+02$ & $7.49 E+62$ & $4.38 E+02$ & $5.63 E+01$ & $6.18 E+01$ \\
\hline $237 \mathrm{~Np}$ & $1.09 \mathrm{E}-01$ & $4.34 E-03$ & $1.07 E-62$ & $6.35 E-63$ & $8.17 E-04$ & $8.96 E-04$ \\
\hline${ }^{231} \mathrm{~Pa}$ & -- & - & -- & --- & -- & -- \\
\hline $233 \mathrm{~Pa}$ & $1.21 E+03$ & $4.82 E+01$ & $1.19 E+02$ & $7.06 \mathrm{E}+01$ & $9.68 E+90$ & $9.95 E+00$ \\
\hline $216_{\mathrm{Pb}}$ & -- & -- & --- & -- & -.- & -- \\
\hline${ }^{218} \mathrm{Po}$ & $2.30 E+\theta \theta$ & $9.14 E-62$ & $2.26 \mathrm{E}-01$ & $1.34 \mathrm{E}-01$ & $1.72 E-82$ & 1.89E- -92 \\
\hline & $1.15 E+\theta 0$ & $4.57 E-02$ & $1.13 \mathrm{E}-81$ & $6.68 \mathrm{E}-02$ & $8.60 E-03$ & $9.43 E-63$ \\
\hline 23 & $1.02 E+00$ & $4.04 E-02$ & $9.98 E-62$ & $5.91 E-02$ & $7.60 E-03$ & 8. $33 E-93$ \\
\hline${ }^{240} \mathrm{Pu}$ & $1.02 E+00$ & $4.94 E-92$ & $9.98 E-02$ & $5.91 E-02$ & $7.60 E-03$ & $8.33 E-93$ \\
\hline $241 \mathrm{Pu}$ & $5.08 E+01$ & $2.02 E+00$ & $4.99 E+00$ & $2.95 E+00$ & $3.80 E-01$ & $4.17 E-81$ \\
\hline${ }_{222}^{242} \mathrm{Pu}$ & $1.38 E+60$ & $5.18 E-92$ & $1.28 \mathrm{E}-01$ & $7.56 \mathrm{E}-0$ & $9.73 E-03$ & $1.87 \mathrm{E}-82$ \\
\hline & $6.63 E+09$ & $2.63 E-61$ & $6.58 E-\theta 1$ & $3.85 E-01$ & $4.95 E-92$ & $5.43 E-62$ \\
\hline${ }^{225} \mathrm{Ra}$ & $1.15 E+01$ & $4.57 E-81$ & $1.13 E+00$ & $6.68 E-91$ & $8.60 \mathrm{E}-62$ & $9.43 E-82$ \\
\hline $226 \mathrm{Ra}$ & --- & -- & --- & -- & $-\cdots$ & --- \\
\hline${ }^{106} \mathrm{Ru}$ & 1. $.32 E+02$ & $6.43 E+80$ & $1.59 E+01$ & $9.41 E+80$ & $1.21 E+B \theta$ & $1.33 E+00$ \\
\hline${ }^{79} \mathrm{Se}$ & --- & -- & --- & $\cdots$ & --- & --- \\
\hline${ }_{156}^{151} \mathrm{Sm}$ & --- & --- & --- & --- & --- & -- \\
\hline${ }^{126} \mathrm{Sn}$ & $2.38 E+02$ & $9.16 E+90$ & $2.26 \mathrm{E}+01$ & $1.34 E+\theta \theta$ & $1.72 E+\theta \theta$ & $1.88 E+06$ \\
\hline${ }^{96} \mathrm{Sr}$ & $3.12 E+01$ & $1.24 E+B \theta$ & 3. $07 E+00$ & $1.81 E+00$ & $2.33 E-61$ & $2.56 \mathrm{E}-01$ \\
\hline${ }^{99} \mathrm{TC}$ & $2.92 E+63$ & $1.16 E+02$ & $2.86 E+02$ & 1. $6^{n} E+02$ & $2.18 E+01$ & $2.39 E+01$ \\
\hline${ }^{229} \mathrm{Th}$ & -- & -- & --- & --- & -- & -- \\
\hline $230 \mathrm{Vh}$ & $7.95 E+00$ & $3.16 E-81$ & $7.80 E-01$ & $4.62 E-01$ & $5.94 E-62$ & $6.51 E-02$ \\
\hline${ }^{232} \mathrm{Th}$ & $1.56 E+\theta 0$ & $6.21 E-02$ & $1.53 E-01$ & $9.07 E-62$ & $1.17 E-62$ & 1.28E-92 \\
\hline${ }_{233}^{234} \mathrm{Th}$ & $3.12 \mathrm{E}+02$ & $1.24 E+01$ & $3.07 E+01$ & $1.81 E+01$ & $2.33 E+\theta 0$ & $2.56 E+00$ \\
\hline $233 \mathrm{U}$ & $1.51 E+01$ & $5.99 E-01$ & $1.48 E+\theta 0$ & $8.76 E-01$ & $1.13 E-01$ & $1.24 E-81$ \\
\hline $234 \mathrm{U}$ & $1.56 E+01$ & $6.20 E-01$ & $1.53 E+\theta 0$ & $9.07 E-01$ & $1.17 E-01$ & 1. $28 \mathrm{E}-91$ \\
\hline $235 \mathrm{U}$ & $1.62 E+01$ & $6.43 E-01$ & $1.59 E+00$ & $9.41 E-01$ & $1.21 E-01$ & 1. $33 E-91$ \\
\hline $236 \mathrm{U}$ & $1.62 \mathrm{E}+01$ & $6.44 E-01$ & $1.59 \mathrm{E}+00$ & $9.41 E-91$ & $1.21 E-81$ & 1. $33 E-81$ \\
\hline $238 \mathrm{U}$ & $1.68 E+01$ & $6.68 \mathrm{E}-01$ & $1.65 E+00$ & $9.77 E-01$ & $1.26 E-61$ & 1. $38 E-01$ \\
\hline $9 \theta_{Y}$ & $3.98 E+02$ & $1.58 \mathrm{E}+01$ & $3.90 E+01$ & $2.31 E+01$ & $2.97 E+00$ & $3.26 E+80$ \\
\hline${ }^{93} \mathrm{Zr}$ & $2.57 E+83$ & $1.02 E+82$ & $2.52 E+92$ & 1. $49 \mathrm{E}+02$ & $1.92 \mathrm{E}+01$ & $2.11 E+01$ \\
\hline
\end{tabular}

-.- Indicates that was not computed or available. 
TABLE E.7. Concentration Thresholds (CTs) for Ground Exposure of Radionuclides

\begin{tabular}{|c|c|c|c|c|c|c|}
\hline \multirow[b]{2}{*}{$\begin{array}{l}\text { Ana lyte } \\
\text { Name }\end{array}$} & \multicolumn{6}{|c|}{ CTs for Tank Farms } \\
\hline & $\begin{array}{l}\text { Group A } \\
(\mu \mathrm{C} i / g)\end{array}$ & $\begin{array}{l}\text { Group B } \\
(1 \mathrm{C} i / g)\end{array}$ & $\begin{array}{l}\text { Group C } \\
(1 \times \mathrm{C} / \mathrm{g})\end{array}$ & $\begin{array}{l}\text { Group S } \\
(\mu \mathrm{Ci} / \mathrm{g})\end{array}$ & $\begin{array}{l}\text { Group T } \\
(\mu \times \mathrm{C} / \mathrm{g})\end{array}$ & $\begin{array}{l}\text { Group U } \\
(\mu \mathrm{C} i / \mathrm{g})\end{array}$ \\
\hline $2: 5 \mathrm{AC}$ & $1.95 E+62$ & $2.05 E+01$ & $1.94 E+01$ & $2.21 E+01$ & $4.39 E+60$ & $3.58 E+60$ \\
\hline $221 \mathrm{AC}$ & -- & -- & $\ldots$ & $-\infty$ & -- & $\ldots$ \\
\hline${ }^{241} \mathrm{Am}$ & $1.06 E+62$ & $1.11 E+01$ & $1.05 E+01$ & $1.2 \theta E+\theta 1$ & $2.38 E+\theta 0$ & $1.94 E+00$ \\
\hline${ }^{242} \mathrm{Am}$ & $1.37 E+02$ & $1.44 E+61$ & $1.36 E+01$ & $1.55 E+61$ & $3.09 E+00$ & $2.52 E+\theta 0$ \\
\hline${ }^{242 m} \mathrm{Am}$ & $1.69 E+63$ & $1.14 E+82$ & 1. $88 \mathrm{E}+02$ & $1.23 E+02$ & $2.45 E+01$ & $2.00 E+01$ \\
\hline${ }^{243} \mathrm{Am}$ & $4.88 E+91$ & $5.12 E+90$ & $4.84 E+60$ & $5.52 E+00$ & $1.10 E+\theta \theta$ & $8.95 E-61$ \\
\hline${ }^{14} \mathrm{C}$ & -- & -.- & -- & -.- & -- & -- \\
\hline${ }^{242} \mathrm{~cm}$ & $3.09 E+03$ & $3.24 E+62$ & $3.06 \mathrm{E}+02$ & $3.50 E+02$ & $6.95 E+01$ & $5.67 E+61$ \\
\hline & $3.71 E+03$ & $3.89 E+82$ & $3.68 E+02$ & $4.26 E+62$ & $8.34 E+01$ & $6.80 E+61$ \\
\hline $245 \mathrm{Cm}$ & $3.75 E+91$ & $3.93 E+90$ & $3.71 E+00$ & $4.24 E+60$ & $8.43 E-01$ & $6.87 E-01$ \\
\hline${ }_{127}^{137} \mathrm{Cs}$ & --- & - & - & -- & - & $\ldots$ \\
\hline${ }^{137} \mathrm{Cs}$ & $2.18 E+\theta 1$ & $2.29 E+\theta 0$ & $2.16 E+\theta \theta$ & $2.47 E+8 \theta$ & $4.91 E-01$ & $4.00 E-01$ \\
\hline${ }_{3}^{60} \mathrm{Co}$ & $1.43 E+60$ & $1.50 E-61$ & 1. $42 E-01$ & $1.61 E-\theta$ & $3.21 E-02$ & $2.61 E-92$ \\
\hline & $1.76 \mathrm{E}-01$ & $3.27 E-81$ & $1.86 \mathrm{E}-02$ & $2.04 E-82$ & $4.09 E-63$ & $3.33 E-93$ \\
\hline${ }_{92}^{129} I$ & $1.43 E+02$ & $1.50 E+01$ & $1.41 E+01$ & $1.61 E+01$ & $3.21 E+\theta \theta$ & $2.62 E+00$ \\
\hline${ }^{93} \mathrm{mb}$ & -- & $\ldots$ & -- & --- & $\ldots$ & -. \\
\hline${ }_{50}^{94} \mathrm{Nb}$ & $2.01 E+\theta 0$ & $2.01 E-01$ & 1.99E-01 & $2.26 \mathrm{E}-61$ & $4.51 E-02$ & $3.66 E-02$ \\
\hline${ }_{63}^{59} \mathrm{Ni}$ & $7.75 E+03$ & $8.12 E+82$ & $7.68 \mathrm{E}+02$ & $8.75 E+02$ & $1.74 E+02$ & $1.42 E+02$ \\
\hline${ }^{63} \mathrm{Ni}$ & --- & -- & -- & -- & -- & -- \\
\hline $237 \mathrm{~Np}$ & $9.77 E+01$ & $1.02 E+01$ & $9.68 E+00$ & $1.10 E+\theta 1$ & $2.2 \theta E+\theta \theta$ & $1.79 E+60$ \\
\hline $231 \mathrm{~Pa}$ & -.. & --- & -- & -- & -- & -- \\
\hline $233 \mathrm{~Pa}$ & $1.37 \varepsilon+01$ & $1.44 E+\theta 0$ & 1. $36 \mathrm{E}+60$ & $1.55 E+\theta \theta$ & $3.09 E-01$ & $2.52 E-01$ \\
\hline $210_{\mathrm{Pb}}$ & --- & --- & -- & -. & -.. & -- \\
\hline $210 \mathrm{PO}$ & $3.71 E+05$ & $3.89 E+84$ & $3.68 E+04$ & $4.20 E+04$ & $8.34 E+03$ & $6.80 E+03$ \\
\hline & $3.37 E+03$ & $3.54 E+02$ & $3.34 E+62$ & $3.82 E+02$ & $7.58 E+01$ & $6.19 E+01$ \\
\hline & $8.87 E+83$ & $8.46 E+82$ & $7.99 E+02$ & $9.12 E+62$ & $1.81 E+02$ & $1.48 E+02$ \\
\hline $24 \theta_{p}$ & $3.71 E+63$ & $3.89 E+02$ & $3.68 \mathrm{E}+02$ & $4.20 E+02$ & $8.34 E+01$ & $6.80 E+61$ \\
\hline $241 p$ & $1.00 E+05$ & 1.05 .04 & $9.94 E+03$ & $1.13 E+64$ & $2.25 E+03$ & $1.84 E+63$ \\
\hline${ }_{223}^{242} \mathrm{Pu}$ & $4.81 E+83$ & $5.05 L+02$ & $4.77 E+02$ & $5.43 E+82$ & $1.68 E+02$ & $8.79 E+01$ \\
\hline${ }^{223} \mathrm{Ra}$ & $2.06 \mathrm{E}+01$ & $2.16 E+60$ & $2.04 E+\theta 0$ & $2.33 E+00$ & 4.64E-01 & $3.78 E-01$ \\
\hline $225 R$ & $2.06 \mathrm{E}+02$ & $2.16 E+\theta 1$ & $2.04 E+01$ & $2.33 E+81$ & 4. $64 E+00$ & $3.78 E+80$ \\
\hline${ }^{22 b} \mathrm{Ra}$ & --- & -- & -- & $\cdots$ & -- & -- \\
\hline${ }_{70}^{106} \mathrm{Ru}$ & $8.84 E+00$ & $9.27 E-61$ & $8.76 E-81$ & $9.99 E-81$ & $1.99 E-01$ & $1.62 E-91$ \\
\hline${ }_{15}^{19} \mathrm{Se}$ & --- & --- & -- & -- & -- & -- \\
\hline${ }_{156}^{151} \mathrm{Sm}$ & --- & -- & --- & -.- & --- & -- \\
\hline${ }^{126} \mathrm{Sn}$ & $5.23 E+01$ & $5.48 E+00$ & $5.18 E+\theta$ & $5.90 E+80$ & $1.17 E+\theta 0$ & $9.55 E-01$ \\
\hline${ }^{90} S r$ & $5.54 \mathrm{E}+02$ & $5.81 E+01$ & $5.49 E+81$ & $6.26 E+01$ & $1.25 E+01$ & $1.02 E+01$ \\
\hline${ }^{99} \mathrm{Tc}$ & $5.16 E+06$ & $5.41 E+85$ & $5.11 E+05$ & $5.83 E+85$ & $1.16 E+85$ & $9.45 E+94$ \\
\hline 240 Th & --- & -- & -- & --- & --- & --- \\
\hline${ }_{230}^{230} \mathrm{Th}$ & $3.37 E+03$ & $3.54 E+82$ & $3.34 E+62$ & $3.82 E+62$ & $7.58 E+01$ & $6.19 E+01$ \\
\hline${ }^{232} \mathrm{Th}$ & $4.58 E+63$ & $4.80 E+82$ & $4.54 E+82$ & $5.17 E+02$ & $1.03 E+02$ & $8.37 E-01$ \\
\hline${ }^{234} \mathrm{Th}$ & $3.69 \mathrm{E}+62$ & $3.24 E+1$ & $3.06 \mathrm{E}+01$ & $3.5 B E+01$ & $6.95 E+90$ & $5.67 E+00$ \\
\hline $233 \mathrm{U}$ & $6.19 E+03$ & $6.49 E+02$ & $6.13 E+02$ & $6.99 E+62$ & 1. $39 E+62$ & 1. $13 E+02$ \\
\hline${ }^{234} \mathrm{U}$ & $3.75 E+63$ & $3.93 E+182$ & $3.71 E+82$ & $4.24 E+82$ & $8.43 E+01$ & $6.87 E+81$ \\
\hline $235 \mathrm{U}$ & $1.86 \mathrm{E}+01$ & $1.95 E+00$ & $1.84 E+\theta \theta$ & $2.10 E+\theta 0$ & $4.17 E-01$ & $3.40 \mathrm{E}-01$ \\
\hline $236 \mathrm{U}$ & 4. $12 E+03$ & $4.32 E+02$ & $4.09 E+02$ & $4.66 E+02$ & $9.27 E+61$ & 7. $53 E+01$ \\
\hline $238 \mathrm{U}$ & $4.64 E+63$ & $4.87 E+02$ & $4.60 E+62$ & $5.25 E+02$ & $1.04 E+62$ & $8.50 E+01$ \\
\hline $90 y$ & $3.69 \mathrm{E}+01$ & $3.24 E+\theta 0$ & $3.06 \mathrm{E}+00$ & $3.50 E+\theta 0$ & $6.95 E-01$ & $5.67 E-31$ \\
\hline${ }^{93} \mathrm{Zr}$ & -- & -- & -- & -- & -- & -.. \\
\hline
\end{tabular}

$\overline{---}$ Indicates that was not computed or available. 
TABLE E.8. Concentration Thresholds (CTs) for Waste Classification

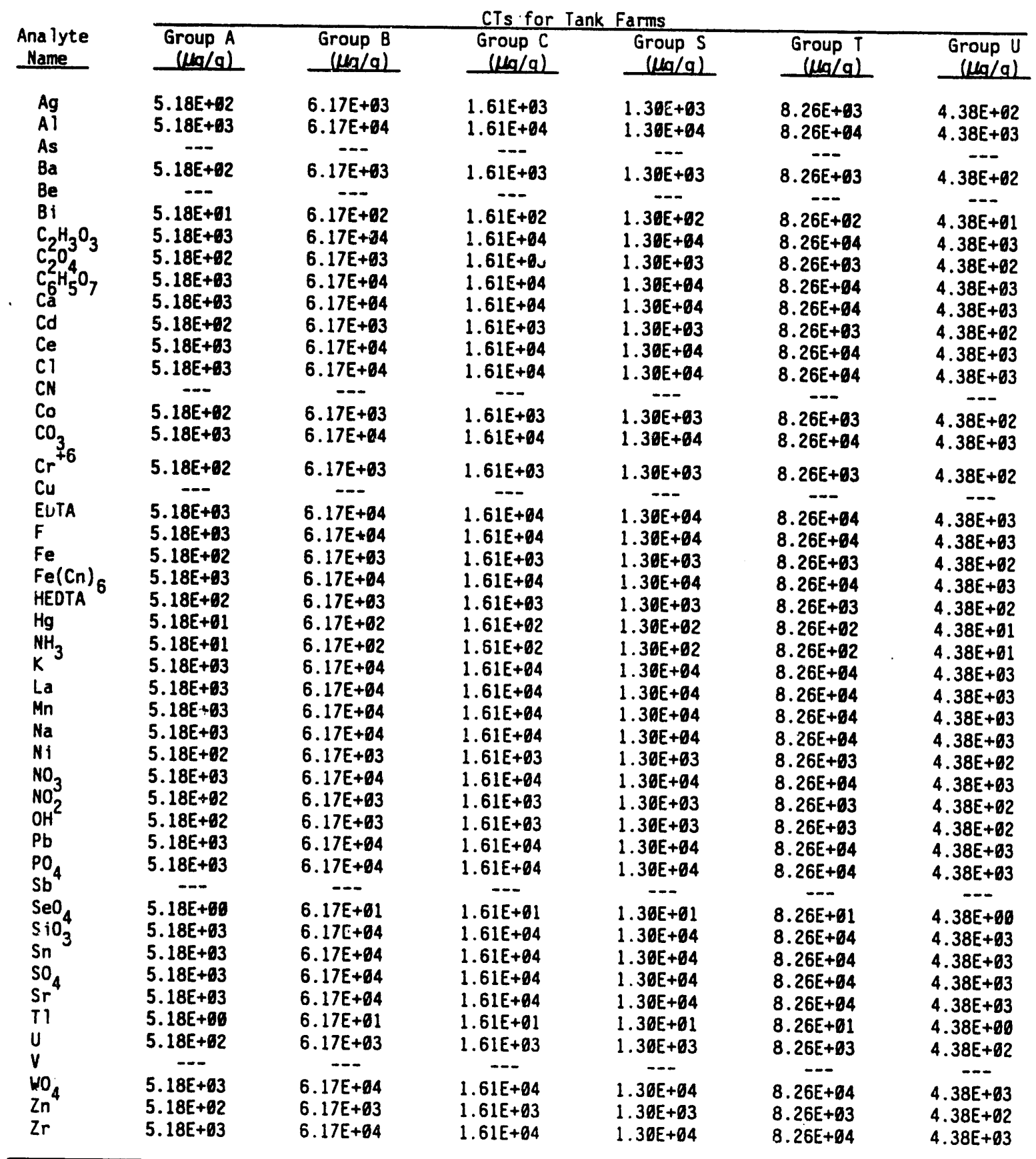


TABLE E.9. Concentration Thresholds (CTs) for Waste Classification Radionuclides

\begin{tabular}{|c|c|c|c|c|c|c|}
\hline \multirow[b]{2}{*}{$\begin{array}{l}\text { Ana lyte } \\
\text { Name } \\
\end{array}$} & \multicolumn{6}{|c|}{ CTs for Tank Farms } \\
\hline & $\begin{array}{l}\text { Group A } \\
(\text { ICi/g) }\end{array}$ & $\begin{array}{l}\text { Group B } \\
(\text { LCi } / g)\end{array}$ & $\begin{array}{l}\text { Group C } \\
(\mu \mathrm{e} j / \mathrm{g})\end{array}$ & $\begin{array}{l}\text { Group } 5 \\
\text { (1)i/g) }\end{array}$ & $\begin{array}{l}\text { Group } T \\
\left(\mu_{C} / / q\right)\end{array}$ & $\begin{array}{l}\text { Group U } \\
(\text { (uc } i / g)\end{array}$ \\
\hline $225_{A C}$ & -- & $-\cdots$ & --- & --- & --- & \\
\hline $227_{A C}^{A C}$ & - & - &.- & -- & - &.-- \\
\hline $241 \mathrm{Am}$ & $1.58 E-62$ & $1.82 E-63$ & 9.03E-63 & $1.76 E-93$ & $7.04 E-64$ & $2.95 E-64$ \\
\hline $242 \mathrm{Am}$ & -- & $\ldots$ & -- & -.- & -- & $\begin{array}{c}1.002-84 \\
---\end{array}$ \\
\hline & $1.58 E-b 2$ & $1.82 E-63$ & $9.03 E-63$ & $1.76 E-63$ & $7.64 E-04$ & $2.95 E-84$ \\
\hline & $1.58 E-32$ & $1.82 E-63$ & $9.63 E-93$ & $1.76 E-63$ & $7.04 E-64$ & $2.95 E-04$ \\
\hline & $7.66 E-01$ & 8.11E-62 & 4.92E-61 & $7.83 E-92$ & $3.13 E-62$ & $1.31 E-62$ \\
\hline & $3.17 E+99$ & $3.65 E-61$ & $1.81 E+\theta 0$ & $3.53 E-61$ & $1.41 E-01$ & $5.89 E-02$ \\
\hline & $1.58 E-62$ & $1.82 E-63$ & $9.013 E-63$ & $1.76 E-63$ & $7.64 E-04$ & $2.95 E-64$ \\
\hline & $1.58 \mathrm{E}-92$ & $1.82 E-63$ & $9.03 \mathrm{E}-93$ & $1.76 E-93$ & $7.04 E-64$ & $2.95 E-04$ \\
\hline${ }^{137} \mathrm{Cs}$ & -- & --- & - & - & --- & $-\cdots$ \\
\hline${ }^{137} \mathrm{Cs}$ & 2. $03 E+\theta 1$ & $2.15 E+00$ & $2.14 E+00$ & $2.34 E+\theta 0$ & 4. $69 E-01$ & $3.82 E-01$ \\
\hline${ }^{9} \mathrm{Co}$ & $3.09 E+00$ & $1.87 E+00$ & $3.25 E-01$ & $3.56 E-01$ & $7.16 E-62$ & $5.83 E-92$ \\
\hline & -- & --- & --- & -- & -- & -- \\
\hline 125 & $7.06 E-93$ & $8.11 E-64$ & $4.02 E-03$ & $7.83 E-94$ & $3.13 E-64$ & $1.31 E-84$ \\
\hline $93 m_{\mathrm{Nb}}$ & --- & --- & - & -- & - & -- \\
\hline${ }_{50}^{94} \mathrm{Nb}$ & $1.76 \mathrm{E}-02$ & $2.02 E-63$ & $1.00 E-02$ & $1.96 \mathrm{E}-63$ & $7.82 E-64$ & $3.28 E-04$ \\
\hline & $1.93 E+91$ & $2.22 E+00$ & $1.10 E+01$ & $2.15 E+\theta 0$ & $8.60 E-91$ & $3.61 E-01$ \\
\hline${ }^{3} \mathrm{Ni}$ & 3. $69 E+69$ & $3.28 E-01$ & $3.25 E-61$ & $3.57 E-81$ & $7.17 E-62$ & $5.83 E-02$ \\
\hline & $1.58 E-02$ & $1.82 E-93$ & $9.03 \mathrm{E}-03$ & $1.76 E-63$ & $7.64 E-64$ & $2.95 E-04$ \\
\hline & -. & -- & -- & -- & -- & -- \\
\hline $\mathrm{Pa}$ & --- & --- &.- & -- & --- & --- \\
\hline $21 \theta_{\mathrm{Pb}}$ & --- &.- & --- & -- & -- &.- \\
\hline${ }^{218} \mathrm{PO}$ & -- & -- & -- & --- & --- & -- \\
\hline & $1.58 E-62$ & $1.82 E-63$ & $9.03 E-63$ & $1.76 E-03$ & $7.04 \mathrm{E}-84$ & $2.95 E^{\prime}-04$ \\
\hline & 1. $58 \mathrm{E}-62$ & $1.82 E-93$ & $9.03 E-03$ & $1.76 E-83$ & $7.04 E-64$ & $2.95 E-04$ \\
\hline & $1.58 E-62$ & $1.82 E-63$ & $9.03 E-93$ & $1.76 E-03$ & $7.64 \mathrm{E}-04$ & $2.95 E-64$ \\
\hline & $5.54 E-61$ & $6.38 E-02$ & $3.16 \mathrm{E}-01$ & $6.17 E-02$ & $2.46 E-92$ & $1.03 E-02$ \\
\hline & --- & --- & -- & $\cdots$ & --- & --- \\
\hline & -- & $-\cdots$ & $\cdots$ & -- & --- & --- \\
\hline $\begin{array}{l}225 \\
226\end{array}$ & $\cdots$ & -- & --- & --- & $\cdots$ & -- \\
\hline 226 & -- & -- & -- & -- & -- & -- \\
\hline${ }_{70}^{186} \mathrm{Ru}$ & --- &.- & $\ldots$ & -- & --- & --- \\
\hline${ }^{79} \mathrm{Se}$ & -- & -- & --- & -- &.- & -.. \\
\hline${ }^{151} \mathrm{Sm}$ & --- & $\cdots$ & -- & -- & --- & --- \\
\hline${ }^{126} \mathrm{Sn}$ & --- & -. & -- & -- & --- & $\cdots$ \\
\hline $90 \mathrm{Sr}$ & $3.09 E+01$ & $3.28 E+00$ & $3.25 E+60$ & $3.57 E+00$ & $7.17 E-01$ & $5.83 E-61$ \\
\hline${ }^{99} \mathrm{Tc}$ & $2.64 E-81$ & $3.04 E-02$ & $1.51 E-61$ & $2.94 E-02$ & $1.17 E-92$ & $4.91 E-63$ \\
\hline${ }^{229} \mathrm{Th}$ & --- & -- & -- & -- & -.- & -.- \\
\hline${ }^{230} \mathrm{Th}$ & --- & -- & -- & -- & -- & -- \\
\hline${ }_{234}^{232} \mathrm{Th}$ & --- & --- & $\cdots$ & -- & --- & --- \\
\hline${ }_{233}^{234} \mathrm{Th}$ & -- & -- & $\cdots$ & --- & --- & -- \\
\hline $233 \mathrm{U}$ & -- & --- & -- & -- &.-- & -- \\
\hline${ }_{234}^{234} \mathrm{U}$ & -- & -- & -.. & -- & --- & -- \\
\hline $235 \mathrm{U}$ & $\cdots$ & -- & --- & --- & -- & -- \\
\hline${ }^{236} \mathrm{U}$ & -- & -- & -- & -- & --- & --- \\
\hline $90^{200}$ & -- & -- & $\cdots$ & --- & --- & -.- \\
\hline $\begin{array}{l}50 y \\
93\end{array}$ & $\cdots$ &.-- & --- & --- & --- & -- \\
\hline${ }^{90} \mathrm{Zr}$ & -- & -- & -- & -- & -.- & --- \\
\hline
\end{tabular}

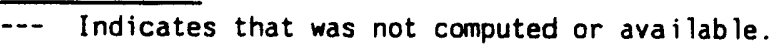


1

APPENDIX $F$

COMPARISON OF DETECTION LIMIT GOALS, ANALYTICAL DETECTION LIMITS, AND $241-B-110$ TRAD AND MEASURED CONCENTRATIONS 
APPENDIX $F$

COMPARISON OF DETECTION LIMIT GOALS, ANALYTICAL DETECTION LIMITS, AND 241-B-110 TRAC AND MEASURED CONCENTRATIONS

TABLE F.1. Detection Limit Goals, Analytical Detection Limits, and 241-B-110 TRAC and Measured Concentrations for Type I Carcinogens ${ }^{(a)}$.

\begin{tabular}{|c|c|c|c|c|}
\hline $\begin{array}{l}\text { Carcinogen } \\
\text { Analyte } \\
\end{array}$ & $\begin{array}{l}\text { Detection } \\
\text { Limit Goal } \\
(\mu \mathrm{Ci} / \mathrm{g}) \\
\end{array}$ & $\begin{array}{c}\text { Analytical } \\
\text { Detection Limit } \\
(\mu \mathrm{Ci} / \mathrm{g}) \\
\end{array}$ & $\begin{array}{c}\text { Measured } \\
241-\mathrm{B}-110 \\
\text { Concentration } \\
(\mathrm{b}) \\
(\mathrm{CC} / \mathrm{g}) \\
\end{array}$ & $\begin{array}{c}\text { TRAC } \\
241-\mathrm{B}-110 \\
\text { Concentration } \\
(\mu \mathrm{Ci} / \mathrm{g}) \\
\end{array}$ \\
\hline${ }^{241} \mathrm{Am}$ & $3.0 E-05$ & $4.0 E-04$ & $7.3 E-02$ & $3.6 E-01$ \\
\hline${ }^{242 m} \mathrm{Am}$ & $3.0 E-05$ & $1.0 E-04$ & $N A^{(c)}$ & $1.4 E-03$ \\
\hline & $6.4 E-06$ & $5.0 E-05^{(d)}$ & $4.0 E-04^{(e)}$ & $3.4 E-02$ \\
\hline${ }^{137} \mathrm{Cs}_{\mathrm{s}}$ & $3.8 E-02$ & $1.0 E-03$ & $1.4 E+01$ & $2.0 E+01$ \\
\hline${ }^{129} I$ & $2.1 E-08$ & $7.0 E-06^{(d)}$ & $3.0 E-05^{(e)}$ & $1.7 E-04$ \\
\hline${ }^{63} \mathrm{Ni}$ & $5.8 E-03$ & $T B D^{(f)}$ & $N A^{(c)}$ & $7.0 E-01$ \\
\hline${ }^{238} \mathrm{Pu}$ & $3.0 E-05$ & $7.0 E-0.05$ & $2.9 \mathrm{E}-03^{(e)}$ & $3.5 E-03$ \\
\hline & $3.0 E-05$ & $7.0 E-05$ & $1.1 \mathrm{E}-01^{(\mathrm{e})}$ & $6.8 E-02$ \\
\hline${ }^{240} \mathrm{Pu}$ & $3.0 E-05$ & $7.0 E-05$ & $1.3 \mathrm{E}-02^{(\mathrm{e})(\mathrm{g})}$ & $1.7 E-02$ \\
\hline${ }^{241} \mathrm{Pu}$ & $1.0 \mathrm{E}-03$ & $1.0 E-05$ & $1.4 \mathrm{E}-01^{(\mathrm{e})(\mathrm{h})}$ & $2.4 E-01$ \\
\hline${ }^{96} \mathrm{Sr}$ & $2.3 E-02$ & $4.0 E-03$ & $9.2 E+01^{(e)}$ & $2.2 E+01$ \\
\hline${ }^{99} \mathrm{Tc}$ & $1.4 \mathrm{E}-06$ & $9.0 E-04$ & $1.8 \mathrm{E}-02^{(e)}$ & $1.0 E-01$ \\
\hline${ }^{235} \mathrm{U}$ & $4.4 E-08$ & 3. $0 E-08$ & $4.9 E-05$ & $1.2 E-04$ \\
\hline${ }^{238} \mathrm{U}$ & $6.8 E-08$ & $2.0 E-07$ & $7.2 \mathrm{E}-05^{(\mathrm{e})}$ & $2.3 E-03$ \\
\hline${ }^{96} Y$ & $5.7 E-02$ & $T B D^{(f)}$ & $N A^{(c)}$ & $2.2 E+01$ \\
\hline
\end{tabular}

(a) ADLs based fusion for radionuclides unless noted otherwise.

(b) All measured data are based on dry weight data unless noted otherwise.

(c) NA indicates data or method is not available.

(d) ADL is based on water leach method.

(e) Measurement based on wet weight data.

(f) TBD indicates detection 7 imit to be determined.

(g) Calculated from ${ }^{246} \mathrm{Pu} /{ }^{239} \mathrm{Pu}$ mass ratio and assumes that the specific activity of the mass ratio is the same as ${ }^{239} \mathrm{Pu}$.

(h) Assumes all activity in measured ${ }^{240} \mathrm{Pu} /{ }^{239} \mathrm{Pu}$ mass ratio is the same as ${ }^{239} \mathrm{Pu}$ and then calculated ${ }^{241} \mathrm{Pu}$ from mass ratio ${ }^{241} \mathrm{Pu} /{ }^{239} \mathrm{Pu}$. 
IABLEF.2. Detection Limit Goals, Analytical Detection Limits, and 241-B-110 TRAC and Measured Concentrations for Type I Noncarcinogens ${ }^{(a)}$

\begin{tabular}{|c|c|c|c|c|}
\hline $\begin{array}{l}\text { Noncarcinogen } \\
\text { Analyte } \\
\end{array}$ & $\begin{array}{l}\text { Detection } \\
\text { Limit Goal } \\
\text { (ug/g) } \\
\end{array}$ & $\begin{array}{c}\text { Analytical } \\
\text { Detection Limit } \\
(\mu \mathrm{g} / \mathrm{g}) \\
\end{array}$ & $\begin{array}{c}\text { Measured } \\
241-\mathrm{B}-110 \\
\text { Concentration } \\
(\mathrm{b}) \\
(\mathrm{gg} / \mathrm{g}) \\
\end{array}$ & $\begin{array}{c}\text { TRAC } \\
241-B-110 \\
\text { Concentration } \\
(\mathrm{kg} / \mathrm{g}) \\
\end{array}$ \\
\hline $\begin{array}{l}\mathrm{Al} \\
\mathrm{Ba} \\
\mathrm{Bi} \\
\mathrm{Cd} \\
\mathrm{Cd}_{6} \mathrm{H}_{5} \mathrm{O}_{7} \\
\mathrm{CN} \\
\mathrm{CO}_{3}\end{array}$ & $\begin{array}{l}6.3 E+00 \\
8.7 E-01 \\
3.9 E+00 \\
5.3 E-01 \\
4.4 E+02 \\
3.8 E-03 \\
3.3 E+02\end{array}$ & $\begin{array}{r}1.3 E+01 \\
9.2 E-01 \\
1.3 E+00 \\
1.6 E+00 \\
T B D^{(c)} \\
T B D^{(c)} \\
T B D^{(c)}\end{array}$ & $\begin{array}{l}2.7 E+03 \\
9.7 E+00 \\
5.9 E+01 \\
4.1 E+01 \\
N A(d) \\
N A(d) \\
4.5 E+03^{(e)}\end{array}$ & $\begin{array}{l}2.7 E+03 \\
4.7 E+00 \\
7.1 E+05 \\
0.0 E+00 \\
3.2 E+04 \\
0.0 E+00 \\
0.0 E+00\end{array}$ \\
\hline $\mathrm{Cr}^{+6}$ & 7.9E-02 & $5.7 E+00$ & $2.3 E+03$ & $5.3 E+02$ \\
\hline $\begin{array}{l}\text { EDTA } \\
\text { F } \\
\text { Fe } \\
\text { HEDTA }\end{array}$ & $\begin{array}{l}8.8 E-04 \\
1.1 E+00 \\
4.4 E+01 \\
4.4 E+01\end{array}$ & $\begin{array}{l}5.0 E+01^{(f)} \\
2.0 E+01^{(f)} \\
2.0 E+00 \\
5.0 E+01^{(f)}\end{array}$ & $\begin{array}{c}9.5 E+02^{(g)} \\
1.95+03^{(h)} \\
4.4 E+04 \\
N A^{(d)}\end{array}$ & $\begin{array}{l}0.0 E+00 \\
5.8 E-40 \\
1.1 E+04 \\
0.0 E+00\end{array}$ \\
\hline Mn & $1.9 E+00$ & $3.7 E-01$ & $2.4 E+02$ & $1.9 E+01$ \\
\hline $\mathrm{Na}$ & $4.8 E+02$ & $3.3 E+01$ & $2.3 E+05$ & $4.1 E+04$ \\
\hline $\mathrm{Ni}$ & $3.9 E+00$ & $5.0 E+00$ & $1.2 E+04$ & $1.5 E+02$ \\
\hline $\mathrm{NO}_{2}$ & $4.3 E-02$ & $4.0 E+01^{(f)}$ & $1.0 E+04^{(h)}$ & $0.0 E+00$ \\
\hline $\begin{array}{l}\mathrm{NO}_{3}^{6} \\
\mathrm{OH}^{2}\end{array}$ & $\begin{array}{l}9.4 E-01 \\
4.4 E+01\end{array}$ & $\begin{array}{c}4.0 E+01^{(f)} \\
N A^{(d)}\end{array}$ & $\begin{array}{c}1.8 E+05^{(h)} \\
N A^{(d)}\end{array}$ & $\begin{array}{l}1.1 E+05 \\
5.8 E+03\end{array}$ \\
\hline $\mathrm{Pb}$ & 2. $7 E+00$ & $5.0 E-01$ & $1.6 E+03$ & $3.5 E-01$ \\
\hline $\mathrm{PO}_{4}$ & $4.3 E+01$ & $4.0 E+01^{(f)}$ & $1.2 E+05$ & $3.2 E+05$ \\
\hline $\mathrm{SiO}_{3}$ & $1.3 E+01$ & $1.5 E+01$ & $6.0 E+04$ & $5.2 E-40$ \\
\hline $\mathrm{SO}_{4}^{3}$ & $4.3 E+02$ & $4.0 E+01^{(f)}$ & $1.1 E+04^{(h)}$ & $1.5 E-09$ \\
\hline $\mathrm{Zr}$ & $4.1 E+02$ & $2.5 E+00$ & $1.4 E+03$ & $3.3 E-01$ \\
\hline
\end{tabular}

(a) ADLs based on acid leach for chemicals unless noted otherwise.

(b) All measured data are based on dry weight data unless noted otherwise.

(c) TBD indicates detection limit to be determined.

(d) NA indicates data or method is not available.

(e) $\mathrm{ADL}$ is based on water leach method for total inorganic content (TIC). data converted to $\mathrm{CO}_{3}$.

(f) ADL is based on water leach method.

(g) ADL is based on water leach method for total organic content (TOC).

(h) Measurement based on wet weight data. 
TABLE F.3. Detection Limit Goals, Analytical Detection Limits, and 241-B-110 TRAC and Measured Concentrations for Type II Carcinogens ${ }^{(a)}$

\begin{tabular}{|c|c|c|c|c|}
\hline $\begin{array}{l}\text { Carcinogen } \\
\text { Analyte } \\
\end{array}$ & $\begin{array}{l}\text { Detection } \\
\text { Limit Goal } \\
(\mu \mathrm{Ci} / \mathrm{g}) \\
\end{array}$ & $\begin{array}{c}\text { Analytical } \\
\text { Detection Limit } \\
(\mu \mathrm{C} / \mathrm{g}) \\
\end{array}$ & $\begin{array}{c}\text { Measured } \\
241-\mathrm{B}-110 \\
\text { Concentration }(b) \\
(\mu \mathrm{C} i / \mathrm{g}) \\
\end{array}$ & $\begin{array}{c}\text { TRAC } \\
241-\mathrm{B}-110 \\
\text { Concentration } \\
(\mathrm{uCi} / \mathrm{g}) \\
\end{array}$ \\
\hline & $3.0 E-05$ & $7.0 \mathrm{E}-03$ & $N A^{(c)}$ & $6.8 E-04$ \\
\hline${ }^{242} \mathrm{Cm}$ & $2.2 E-04$ & $5.0 E-05$ & $N A^{(c)}$ & $1.0 \mathrm{E}-03$ \\
\hline${ }^{244} \mathrm{Cm}$ & $3.0 E-05$ & $4.0 E-04$ & $8.6 E-04^{(d)}$ & $3.4 E-03$ \\
\hline${ }^{93 m} \mathrm{Nb}$ & $N A^{(c)}$ & $T B D^{(e)}$ & $N A^{(c)}$ & $1.4 E-02$ \\
\hline${ }^{237} \mathrm{~Np}$ & $3.0 E-05$ & $1.6 E+00^{(f)}$ & $1.2 E-04^{(d)}$ & $1.0 \mathrm{E}-05$ \\
\hline${ }^{234} U$ & $3.5 E-04$ & $1.0 E-11$ & $8.4 E+01$ & $8.5 E-07$ \\
\hline${ }^{233} U$ & $3.5 E-04$ & $7.0 \mathrm{E}-12$ & $N A^{(c)}$ & $1.4 E-09$ \\
\hline
\end{tabular}

(a) ADLs based fusion for radionuclides unless noted otherwise.

(b) All measured data are based on dry weight data unless noted otherwise.

(c) NA indicates data or method is not available.

(d) Measurement based on wet weight data.

(e) TBD indicates detection limit to be determined.

(f) $A D L$ is based on water leach method.

IABLE F.4. Detection Limit Goals, Analytical Detection Limits, and 241-B-110 TRAC and Measured Concentrations for Type II
Noncarcinogens

\begin{tabular}{|c|c|c|c|c|}
\hline $\begin{array}{c}\begin{array}{c}\text { Noncarcinogen } \\
\text { Analyte }\end{array} \\
\end{array}$ & $\begin{array}{l}\text { Detection } \\
\text { Limit Goal } \\
\text { ( } \mathrm{kg} / \mathrm{g}) \\
\end{array}$ & $\begin{array}{c}\text { Analytical } \\
\text { Detection Limit } \\
(\mu \mathrm{g} / \mathrm{g}) \\
\end{array}$ & $\begin{array}{c}\text { Measured } \\
241-B-110 \\
\text { Concentrat ion } \\
(\mathrm{b}) \\
(\mu \mathrm{g} / \mathrm{g}) \\
\end{array}$ & $\begin{array}{c}\text { TRAC } \\
241-B-110 \\
\text { Concentration } \\
(\mu \mathrm{g} / \mathrm{g}) \\
\end{array}$ \\
\hline $\begin{array}{l}\mathrm{Ag} \\
\mathrm{Ca} \\
\mathrm{C}_{2} \mathrm{H}_{3} \mathrm{O}_{3} \\
\mathrm{Fe}^{2}(\mathrm{CN})_{6} \\
\mathrm{~K}\end{array}$ & $\begin{array}{l}1.9 E+01 \\
1.8 E+02 \\
4.4 E+02 \\
8.9 E+01 \\
4.4 E+02\end{array}$ & $\begin{array}{r}3.9 E+00 \\
3.6 E-01 \\
T B D(d) \\
T B D^{(d)} \\
1.3 E+02\end{array}$ & $\begin{array}{l}\text { 8.6E+01 } \\
\text { 5. } 8 E+Q 1^{(c)} \\
N A(e) \\
N A(e) \\
9.0 E+02\end{array}$ & $\begin{array}{l}1.1 E-06 \\
5.5 E+00 \\
0.0 E+00 \\
0.0 E+00 \\
0.0 E+00\end{array}$ \\
\hline
\end{tabular}

(a) ADLs based on acid leach for chemicals unless noted otherwise.

(b) All measured data are based on dry weight data unless noted otherwise.

(c) Measurrment based on wet weight data.

(d) TBD inficates detection limit to be determined.

(e) NA indicates data or method is not available. 
TABLE F.5. Detection Limit Goals, Analytical Detection Limits, and 241-B-110 TRAC and Measured Concentrations for Type III Carcinogens

\begin{tabular}{|c|c|c|c|c|}
\hline $\begin{array}{l}\text { Carcinoge., } \\
\text { Analyte }\end{array}$ & $\begin{array}{l}\text { Detection } \\
\text { Limit Goal } \\
\text { (uCi/g) }\end{array}$ & $\begin{array}{c}\text { Analytical } \\
\text { Detection Limit } \\
(\mu \mathrm{C} / \mathrm{g}) \\
\end{array}$ & $\begin{array}{c}\text { Measured } \\
241-\mathrm{B}-110 \\
\text { Concentration } \\
(\mu \mathrm{Ci} / \mathrm{g}) \\
\end{array}$ & $\begin{array}{c}\text { TRAC } \\
241-\mathrm{B}-110 \\
\text { Concentration } \\
(\mu \mathrm{C} i / \mathrm{g}) \\
\end{array}$ \\
\hline${ }^{225} \mathrm{AC}$ & $4.1 E-03$ & $T B D^{(a)}$ & $N A^{(b)}$ & $1.7 \mathrm{E}-12$ \\
\hline${ }^{227} \mathrm{AC}$ & $N A^{(b)}$ & $T B D^{(a)}$ & $N A^{(b)}$ & $6.4 \mathrm{E}-08$ \\
\hline${ }^{242} \mathrm{Am}$ & $4.1 E-05$ & $7.0 \mathrm{E}-07^{(\mathrm{c})}$ & $N A^{(b)}$ & $1.0 E-03$ \\
\hline${ }^{245} \mathrm{Cm}$ & $3.0 E-05$ & $2.0 E-01^{(c)}$ & $N A^{(b)}$ & $3.4 \mathrm{E}-07$ \\
\hline${ }^{135} \mathrm{Cs}$ & $N A^{(b)}$ & $T B D^{(a)}$ & $N A^{(b)}$ & $6.8 E-05$ \\
\hline${ }^{231} \mathrm{~Pa}$ & $N A^{(b)}$ & $\mathrm{TBD}^{(\mathrm{a})}$ & $N A^{(b)}$ & $1.4 E-07$ \\
\hline${ }^{233} \mathrm{~Pa}$ & $2.5 E-02$ & $T B D^{(a)}$ & $N A^{(b)}$ & $1.0 E-05$ \\
\hline${ }^{210} \mathrm{~Pb}$ & $N A^{(b)}$ & $T B D^{(a)}$ & $N A^{(b)}$ & $1.7 E-12$ \\
\hline${ }^{210} \mathrm{PO}_{\mathrm{O}}$ & $1.7 E-03$ & $\mathrm{TBO}^{(\mathrm{a})}$ & $N A^{(b)}$ & $1.7 E-12$ \\
\hline${ }^{223} \mathrm{Ra}$ & $5.0 E-03$ & $T B D^{(a)}$ & $N A^{(b)}$ & $6.4 E-08$ \\
\hline${ }^{225} \mathrm{Ra}$ & $5.8 E-03$ & $T B D^{(a)}$ & $N A^{(b)}$ & $1.7 E-13$ \\
\hline${ }^{226} \mathrm{Ra}$ & $N A^{(b)}$ & $\mathrm{TBD}^{(\mathrm{a})}$ & $N A^{(b)}$ & $5.4 E-13$ \\
\hline${ }^{228} \mathrm{Ra}$ & $N A^{(b)}$ & $\mathrm{TBD}^{(\mathrm{a})}$ & $N A^{(b)}$ & $N A^{(b)}$ \\
\hline${ }^{186} \mathrm{Ru}$ & $1.6 \mathrm{E}-02$ & $\mathrm{TBD}^{(\mathrm{a})}$ & $N A^{(b)}$ & $3.4 E-06$ \\
\hline${ }^{79} \mathrm{Se}$ & $N A^{(b)}$ & $\mathrm{TBD}^{(\mathrm{a})}$ & $N A^{(b)}$ & $2.7 E-03$ \\
\hline${ }^{151} \mathrm{Sm}$ & $N A^{(b)}$ & $\mathrm{TBD}^{(\mathrm{a})}$ & $N A^{(b)}$ & $3.4 \mathrm{E}+00$ \\
\hline${ }^{229} \mathrm{Th}$ & $N A^{(b)}$ & $T B D^{(a)}$ & $N A^{(b)}$ & $1.7 E-12$ \\
\hline${ }^{230} \mathrm{Th}$ & $1.4 E-04$ & $\mathrm{TBD}^{(\mathrm{a})}$ & $N A^{(b)}$ & $8.8 E-12$ \\
\hline${ }^{234} \mathrm{Th}$ & $2.3 E-01$ & $\mathrm{TBO}^{(\mathrm{a})}$ & $N A^{(b)}$ & 2. $3 E-03$ \\
\hline
\end{tabular}

(a) TBD indicates detection limit to be determined.

(b) NA indicates data or method is not available.

(c) ADLs based fusion for radionuclides. 
TABLE F.6. Detection Limit Goals, Analytical Detection Limits, and 241-B-110 TRAC and Measured Concentrations for Type III Noncarcinogens ${ }^{(a)}$

\begin{tabular}{|c|c|c|c|c|}
\hline $\begin{array}{l}\text { Noncarcinogen } \\
\text { Analyte }\end{array}$ & $\begin{array}{l}\text { Detection } \\
\text { Limit Goal } \\
\text { (us'g) } \\
\end{array}$ & $\begin{array}{c}\text { Analytical } \\
\text { Detection Limit } \\
(\mu \mathrm{g} / \mathrm{g}) \\
\end{array}$ & $\begin{array}{c}\text { Measured } \\
241-\mathrm{B}-110 \\
\text { Concentration }(\mathrm{b}) \\
(\mu \mathrm{g} / \mathrm{g}) \\
\end{array}$ & $\begin{array}{c}\text { TRAC } \\
241-\mathrm{B}-110 \\
\text { Concentration } \\
(\mu \mathrm{g} / \mathrm{g})\end{array}$ \\
\hline $\begin{array}{l}\mathrm{Ce} \\
\mathrm{Cl} \\
\mathrm{C}_{2} \mathrm{O}_{4} \\
\mathrm{La}_{4} \\
\mathrm{SeO}_{4} \\
\mathrm{Sn}_{4} \\
\mathrm{HO}_{4}\end{array}$ & $\begin{array}{l}3.8 E+02 \\
1.1 E+00 \\
3.2 E+01 \\
4.4 E+02 \\
2.9 E-01 \\
4.5 E+01 \\
2.1 E+02\end{array}$ & $\begin{array}{l}5.4 E+01 \\
2.0 E+Q \mathcal{C}(c) \\
T B D(d) \\
4.8 E+00 \\
5.0 E-Q 1 \\
N A(e) \\
N A(e)\end{array}$ & $\begin{array}{c}\text { 1. } 3 E+02 \\
1.2 E+Q 3 \\
N A \\
2.0 E+Q 2 \\
N A(e) \\
N A(e) \\
N A(e)\end{array}$ & $\begin{array}{l}0.0 E+00 \\
0.0 E+00 \\
0.0 E+00 \\
0.0 E+00 \\
0.0 E+00 \\
0.0 E+00 \\
0.0 E+00\end{array}$ \\
\hline
\end{tabular}

(a) ADLs based on acid leach for chemicals unless noted otherwise.

(b) All measured data are based on dry weight data unless noted otherwise.

(c) ADL is based on water leach method.

(d) TBD indicates detection limit to be determined.

(e) NA indicates data or method is not available. 
TABLE F.7. Detection Limit Goals, Analytical Detection Limits, and 241-B-110 TRAC and Measured Concentrations for Unranked

\begin{tabular}{|c|c|c|c|c|}
\hline $\begin{array}{l}\text { Carcinogen } \\
\text { Analyte } \\
\end{array}$ & $\begin{array}{l}\text { Detection } \\
\text { Limit Goal } \\
(\mu \mathrm{C} i / g) \\
\end{array}$ & $\begin{array}{c}\text { Analytical } \\
\text { Detection Limit } \\
(\mu \mathrm{C} i / \mathrm{g}) \\
\end{array}$ & $\begin{array}{c}\text { Measured } \\
241-B-110 \\
\text { Concentration } \\
(\mathrm{b}) \\
(\mu \mathrm{C} i / \mathrm{g}) \\
\end{array}$ & $\begin{array}{c}\text { TRAC } \\
241-\mathrm{B}-110 \\
\text { Concentration } \\
(\mu \mathrm{C} i / g) \\
\end{array}$ \\
\hline $\begin{array}{l}{ }^{\mathrm{As}} \\
{ }^{65} \mathrm{Co} \\
{ }^{3} \mathrm{H} \\
{ }^{94} \mathrm{Nb} \\
{ }^{59} \mathrm{Ni} \\
{ }^{242} \mathrm{Pu} \\
{ }^{126} \mathrm{Sn} \\
{ }^{232} \mathrm{Th} \\
{ }^{236} \mathrm{U} \\
{ }^{93} \mathrm{Zr}\end{array}$ & $\begin{array}{c}1.7 E-03^{(c)} \\
T B D^{(f)} \\
T B D^{(f)} \\
T B D^{(f)} \\
T B D^{(f)} \\
T B D^{(f)} \\
T B D^{(f)} \\
T B D^{(f)} \\
2.6 E-G 8 \\
T B D^{(f)}\end{array}$ & $\begin{array}{c}7.0 E-03^{(c)(d)} \\
T B D^{(f)} \\
8.0 E-05 \\
T B D^{(f)} \\
T B D^{(f)} \\
3.0 E-01 \\
T B D^{(f)} \\
T B D^{(f)} \\
1.0 E-09 \\
T B D^{(f)}\end{array}$ & $\begin{array}{l}5.6 E+01^{(c)} \\
4.4 E-04 \\
2.2 E-03^{(g)} \\
N A^{(e)} \\
N A^{(e)} \\
2.4 E-06^{(h)} \\
N A^{(e)} \\
N A^{(e)} \\
1.5 E+000^{(i)} \\
N A^{(e)}\end{array}$ & $\begin{array}{l}N A^{(e)} \\
N A^{(e)} \\
N A^{(e)} \\
N A^{(e)} \\
N A^{(e)} \\
N A^{(e)} \\
N A^{(e)} \\
N A^{(e)} \\
N A^{(e)} \\
N A^{(e)}\end{array}$ \\
\hline
\end{tabular}

(a) ADLs based fusion for radionuclides unless noted otherwise.

(b) All measured data are based on dry weight data unless noted otherwise.

(c) Units for As are in $\mu \mathrm{g} / \mathrm{g}$.

(d) $A D L$ for As is based on water leach method with units of $\mu \mathrm{g} / \mathrm{g}$.

(e) NA indicates data or method is not available.

(f) TBD indicates detection limit to be determined.

(g) Measurement based on wet weight data.

(h) Calculated from ${ }^{248} \mathrm{Pu} /{ }^{239} \mathrm{Pu}$ mass ratio assuming the specific activity of this mass ratio is the same as ${ }^{239} \mathrm{Pu}$.

(i) Calculated from ${ }^{236} \mathrm{U} /{ }^{238} \mathrm{U}$ mass ratio and total ${ }^{238} \mathrm{U}$ mass in fusion sample. 
TABLE F.8. Detection Limit Goals, Analytical Detection Limits, and 241-B-110 TRAC and Measured Cuncentrations for Unranked Noncarcinogens ${ }^{(a)}$

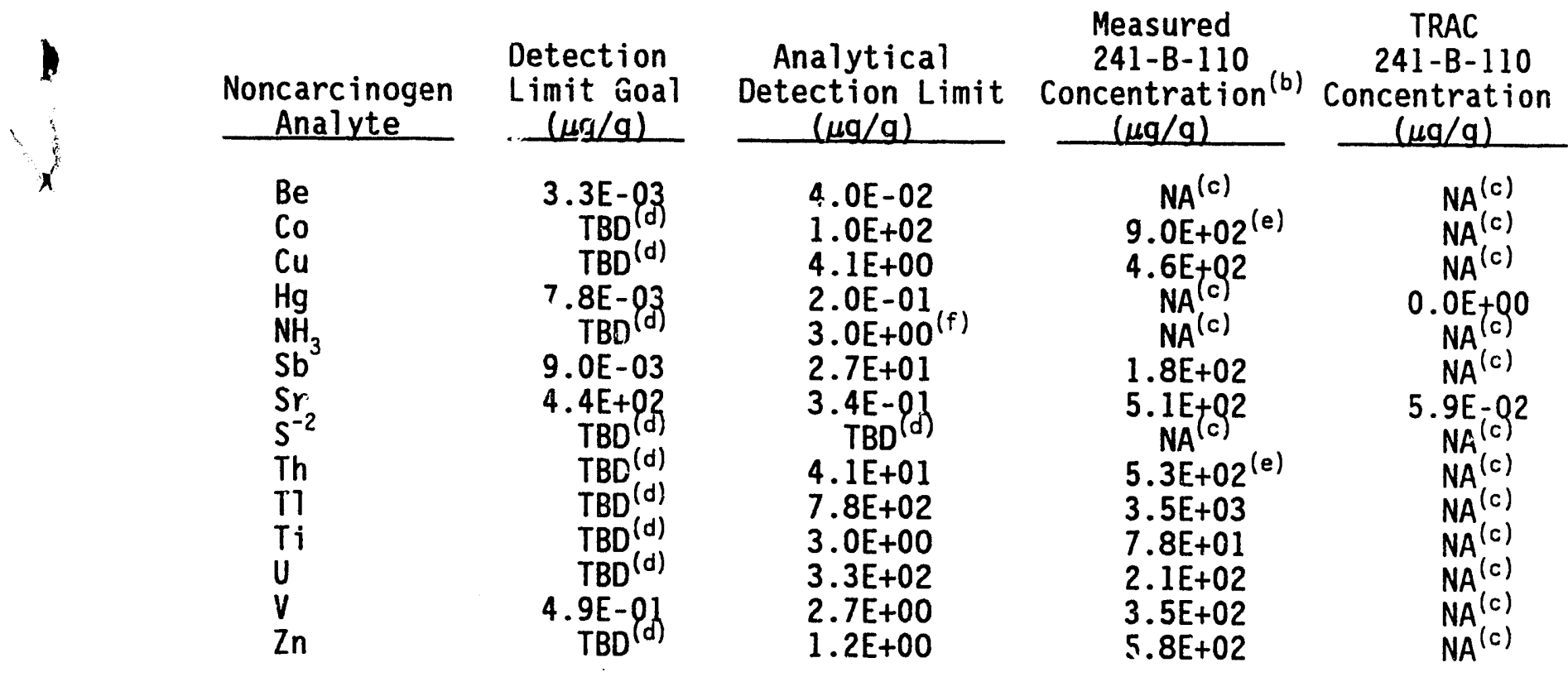

(a) ADLs based on acid leach for chemicals unless noted otherwise.

(b) All measured data are based on dry weight data uniess noted otherwise.

(c) NA indicates data or method is not available.

(d) TBD indicites detection limit to be determined.

(e) Measurement based on wet weight data.

(f) ADL is based on water leach method. 


\section{DISTRIBUTION}

No. of

Copies

OFFSITE

2 DOE/Office of Scientific and Iechnical Information

15 R. S. Andrews

National Academy of Sciences 2101 Constitution Ave., N.W. Washington, DC 20418

5 R. J. Aiken

Environmental Management U.S. Department of Energy Forrestal Building, EM-20 1000 Independence Avenue S.W. Hashington, DC 20545

P. Beam

U.S. Department of Energy DP-124

19901 Germantown Road

Germantown, MD 20545

J. C. Lehr

On-Site Remediation Branch

U.S. Department of Energy

Germantown, EM-442

Washington, DC 20545

T. Longo

U.S. Department of Energy

DF- 124

19901 Germantown Road

Germantown, MD 20545

J. Tseng

U.S. Department of Energy

Trevion Building 2, EM/35

12800 Middlebrook Road

Germantown, MD 20874
No. of

Copies

3 R. S. Stanley (2)

M. Lerchen (1)

State of Washington

Department of Ecology

Mail Stop PV-11

O1ympia, WA 98504-8711

ONSITE

9 DOE Field office, Richl and

M. J. Anthony

P. K. Clark

R. D. Freeberg

R. E. Gerton

J. M. Hennig

J. E. Newson

D. E. Trader

A5-18

A5-21

A5- 19

A4-02

A5-21

R4-04

Public Reading Room (2) Al-65

2 U.S. Environmental Protection Agency

P. T. Day

B5-01

D. R. Sherwood

B5-01

Stone Webster Engineering

B. J. Tucker

A4-35

47 Westinghouse Hanford Company

M. R. Adams

H4-55

H. Babad

D. E. Ball

H4-23

L. M. Bergmann

A. L. Boldt

K. D. Boomer

J. W. Cammann

A. J. Diliberto

G6-46

H4-55

H5-49

H5-49

H4-14

R2-18 
PNL-7573, Vol . 2

UC-702,721

No. of

Copies

J. S. Garfield

R3-63

C. E. Golberg

H5- 49

J. G. Granger

V. W. Hall

J. G. Hill

L. Jensen

J. H. Kessner

M. J. Klem

R. J. Landon

R. E. Lerch

H. E. McGuire

R. E. Miller

R. L. Miller

A. F. Noonan

B. E. Opitz

J. G. Propson

R. E. Raymond

L. M. Sasaki

E. H. Smith

J. C. Sonnichsen

M. B. Walter

R. L. Weiss

N. R. Wing

W. I. Winters

D. D. Wodrich

R. D. Wojtasek

J. C. Womack

D. E. Wood

M. I. Wood

Central Files

Environmental Data

Management Center (6)

Publications Services
H4-57

L4-88

R2-12

T6-18

T6-08

R2-14

B2-19

B2 -35

B2-35

T3-02

L4-88

R2 -12

R2-83

R2-18

R1-80

R2-12

B2-19

H4-14

K6-96

T6-08

H4-14

T6-50

B3-72

L4-92

LO- 18

B2-19

N3-12

L8-18

H4-22

L8-07
No. of

Copies

86 Pacific Northwest Laboratory

S. Q. Bennett

K6-35

W. F. Bonner

J. W. Buck (25)

P7 -44

P. J. Chamberlain

P. G. Doctor

J. G. Droppo (5)

R. M. Ecker

K6-96

K7 -34

K6-96

J. W. Falco

K6-96

SEQUI

K6-78

J. F. Fletcher

K6-31

M. D. Freshiey

K6-77

J. M. Hales

P. C. Hays

K6-04

G. M. Holter

K6-86

V. L. Hunter

K6-25

S. T. Hwang

K6-31

B. M. Johnson, Jr.

K6-96

T. E. Jones

K1-51

J. F. Keller

P7 -27

$\mathrm{K} 1-51$

G. M. McNair

K6-25

M. S. Peffers (20)

K6-25

P. A. Scott

P7 -43

R. J. Serne

K6-81

T. L. Stewart

K5-25

K3-51

K. M. Strenge

K6-25

R. S. Wegeng

K6-31

G. Whelan

K6-96

J. S. Wilbur

K6-96

T. W. Wood (5)

K6-25

Publishing Coordination

Technical Report Files 
$-$
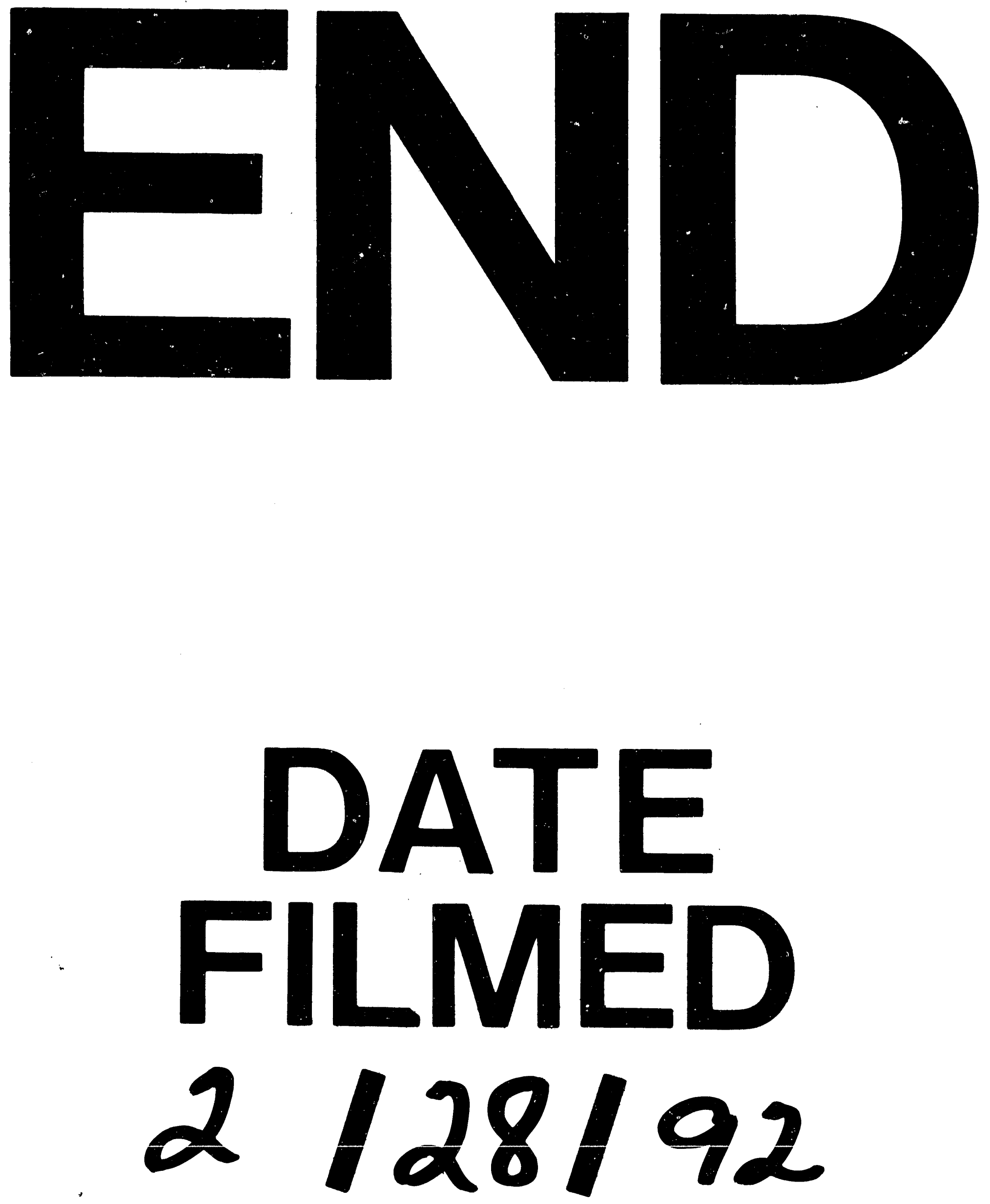
